This document was prepared in conjunction with work accomplished under Contract No. DE-AC09-96SR18500 with the U. S. Department of Energy.

\title{
DISCLAIMER
}

This report was prepared as an account of work sponsored by an agency of the United States Government. Neither the United States Government nor any agency thereof, nor any of their employees, nor any of their contractors, subcontractors or their employees, makes any warranty, express or implied, or assumes any legal liability or responsibility for the accuracy, completeness, or any third party's use or the results of such use of any information, apparatus, product, or process disclosed, or represents that its use would not infringe privately owned rights. Reference herein to any specific commercial product, process, or service by trade name, trademark, manufacturer, or otherwise, does not necessarily constitute or imply its endorsement, recommendation, or favoring by the United States Government or any agency thereof or its contractors or subcontractors. The views and opinions of authors expressed herein do not necessarily state or reflect those of the United States Government or any agency thereof. 


\title{
PHYSICAL PROPERTIES OF KAOLIN/SAND SLURRY USED DURING SUBMERSIBLE MIXER PUMP TESTS AT TNX
}

\author{
Author: $\quad$ Erich Hansen \\ Vickie Williams
}

November 2005 


\title{
DISCLAIMER
}

This report was prepared by Westinghouse Savannah River Company (WSRC) for the United States Department of Energy under Contract No. DE-AC09-96SR18500 and is an account of work performed under that contract. Neither the United States Department of Energy, nor WSRC, nor any of their employees makes any warranty, expressed or implied, or assumes any legal liability or responsibility for the accuracy, completeness, or usefulness, of any information, apparatus, or product or process disclosed herein or represents that its use will not infringe privately owned rights. Reference herein to any specific commercial product, process, or service by trademark, name, manufacturer or otherwise does not necessarily constitute or imply endorsement, recommendation, or favoring of same by WSRC or by the United States Government or any agency thereof. The views and opinions of the authors expressed herein do not necessarily state or reflect those of the United States Government or any agency thereof.

\author{
Printed in the United States of America \\ Prepared For \\ U.S. Department of Energy
}


Key Words: Kaolin, physical Properties, Submersible mixer pump

Retention: Permanent

\section{PHYSICAL PROPERTIES OF KAOLIN/SAND SLURRY USED DURING SUBMERSIBLE MIXER PUMP TESTS AT TNX}

$\begin{array}{ll}\text { Author: } & \text { Erich Hansen } \\ & \text { Vickie Williams }\end{array}$

November 2005 


\section{REVIEWS AND APPROVALS}

\section{AUTHQR(S):}

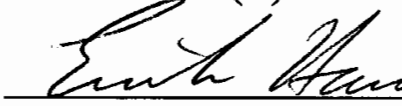

Erich Hansen, Immobilization Technology Section

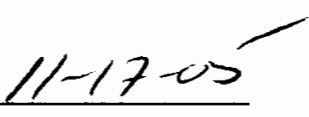

$\frac{\text { Heitue Zleleams }}{\text { Vickie Williams, Immobilization Technology Section }}$

TECHNICAL REVIEWERS:

Jare Danes

Gene Daniel, Immobilization Technology Section

$11-17-05$

Date

\section{APPROVERS}

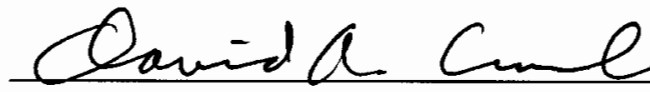

$11 / 12 / 05$

D. A. Crowley, Manager, Immobilization Technology and Business Development Date 


\section{EXECUTIVE SUMMARY}

The purpose of this task is to characterize the physical properties of the kaolin/sand slurries used during the testing of a new submersible mixer pump (SMP) which had undergone performance testing at the TNX Waste Tank mockup facility from July 2004 through May 2005. During this time period, four identical SMPs were subjected to various water tests and four different tests using different batches of kaolin/sand slurries. The physical properties of the kaolin/sand slurries were measured for three of the four tests. In these tests, three different sample locations were used to pull samples, the SMP cooling water exit (CWE), the SMP fluid flow field (FFF), and SMP effective cleaning radius (ECR). The physical properties measured, though not for each sample, included rheology, weight percent total solids (wt\% TS), density, kaolin/sand slurry particle size distribution (PSD), weight percent and particles size distribution of material greater than 45 microns.

The measured physical properties for each test are described in more detail in section 1.0. Measurements were performed at Savannah River National Laboratory (SRNL) in accordance with the Technical Assistance Request (TAR) ${ }^{1}$.

The data, average of two measurements, are shown in the tables below for the different test dates. The data clearly shows that the SMP-CWE samples consistently contained more solids than those at the other two sample locations for any given sample day. This means that the pump is slightly segregating more solids into the SMP cooling system. The SMP-FFF and SMP-ECR had similar physical properties, where these samples are pulled from flowing streams within the test tank. Some of the SMP-ECR data was inconsistent with the SMP-CWE and SMP-FFF data, which could be due to where/how the SMP-ECR samples were pulled. The rheology of the samples is dependent on the wt $\%$ solids concentration and all were within the bounds stated in the TAR. The slurry used in the May 2005 test contained lower total solids and was rheologically much thinner than the kaolin/sand slurries used in the June 2004 and September 2004 tests. Details of the wt\% TS, density and rheology analyses and results are discussed in more detail in sections 1.1, 1.2, and 1.3 respectively.

The particle size, using the Microtrac S3000, showed that from a numbers perspective, the nominal particle size was approximately the same for any sample that was analyzed. The S3000 volume distributions cannot be used to determine the contribution of sand in the slurries.

During the September 2004 test, additional samples were pulled on the $4^{\text {th }}, 7^{\text {th }}$ and $10^{\text {th }}$ day of testing. These samples were used to determine the mass of kaolin/sand particles greater than 45 microns in the kaolin/sand slurries. The sand analyses indicate that a majority of the sand was not adequately suspended in the kaolin based slurry.

During the May 2005 test, sand analyses were performed for samples pulled on the $1^{\text {st }}$, $2^{\text {nd }}$, and $7^{\text {th }}$ day of testing. The results, for the SMP-CWE location, showed that the sand contribution on the $1^{\text {st }}$ day was approximately around the targeted value of $10 \mathrm{wt} \%$ of the total solids. This sample was pulled after the sand was initially loaded into the mixing tank. On the $2^{\text {nd }}$ day, the SMP-CWE sample was less than $4 \mathrm{wt} \%$ and by the $7^{\text {th }}$ day it was less than $0.6 \mathrm{wt} \%$. The other samples locations were much less in wt\% TS sand for the $1^{\text {st }}$ and $2^{\text {nd }}$ day as compared to the SMP-CWE location. By the $7^{\text {th }}$ day, all three sample locations were similar in wt\% TS sand.

\footnotetext{
${ }^{1}$ Altman, D., “Testing and Sampling support at TNX for Submersible Mixer Pump (SPM) Test”, HAL-TAR2004-077, Rev. 2, September 9, 2004
} 
Particle size distribution, both Microtrac and sand analyses are discussed in more detail in section 1.4.

July 2004 SMP Kaolin/Sand Slurry Test

\begin{tabular}{|c|c|c|c|c|c|}
\hline \multirow{2}{*}{$\begin{array}{l}\text { Sample } \\
\text { location }\end{array}$} & \multirow{2}{*}{$\begin{array}{l}\text { Day } \\
\text { Pulled }\end{array}$} & \multicolumn{4}{|c|}{ Average of Two Measurements } \\
\hline & & wt\% T.S. & Density (g/mL) & $\begin{array}{l}\text { Yield stress } \\
\left(\text { dynes } / \mathrm{cm}^{2}\right)\end{array}$ & $\begin{array}{c}\text { Plastic } \\
\text { viscosity }(\mathrm{cP})\end{array}$ \\
\hline \multirow{7}{*}{ SMP-CWE } & 1 & 25.17 & 1.180 & 122.0 & 8.04 \\
\hline & 2 & 24.04 & 1.171 & 107.9 & 7.52 \\
\hline & 3 & 23.86 & 1.171 & 107.6 & 7.43 \\
\hline & 4 & 23.89 & 1.173 & 109.2 & 7.42 \\
\hline & 5 & 23.01 & 1.165 & 95.6 & 6.86 \\
\hline & 6 & 23.02 & 1.164 & 99.0 & 7.03 \\
\hline & 7 & 23.23 & 1.167 & 97.9 & 7.03 \\
\hline \multirow{7}{*}{ SMP-FFF } & 1 & 24.32 & 1.177 & $\mathrm{~N} / \mathrm{M}$ & $\mathrm{N} / \mathrm{M}$ \\
\hline & 2 & 23.72 & 1.167 & $\mathrm{~N} / \mathrm{M}$ & $\mathrm{N} / \mathrm{M}$ \\
\hline & 3 & 23.49 & 1.165 & $\mathrm{~N} / \mathrm{M}$ & $\mathrm{N} / \mathrm{M}$ \\
\hline & 4 & 23.41 & 1.169 & $\mathrm{~N} / \mathrm{M}$ & $\mathrm{N} / \mathrm{M}$ \\
\hline & 5 & 22.77 & 1.162 & $\mathrm{~N} / \mathrm{M}$ & $\mathrm{N} / \mathrm{M}$ \\
\hline & 6 & 22.69 & 1.161 & $\mathrm{~N} / \mathrm{M}$ & $\mathrm{N} / \mathrm{M}$ \\
\hline & 7 & 22.92 & 1.164 & $\mathrm{~N} / \mathrm{M}$ & $\mathrm{N} / \mathrm{M}$ \\
\hline \multirow{3}{*}{ SMP-ECR } & 3 & 23.51 & 1.168 & 104.3 & 7.21 \\
\hline & 6 & 22.06 & 1.157 & 83.3 & 6.39 \\
\hline & 7 & 22.97 & 1.165 & 96.7 & 6.98 \\
\hline
\end{tabular}

$\mathrm{N} / \mathrm{M}=$ not measured

September 2004 SMP Kaolin/Sand Slurry Test

\begin{tabular}{|c|c|c|c|c|c|}
\hline \multirow[b]{2}{*}{ Sample location } & \multirow[b]{2}{*}{$\begin{array}{l}\text { Day } \\
\text { Pulled }\end{array}$} & \multicolumn{4}{|c|}{ Average of Two Measurements } \\
\hline & & wt\% T.S. & Density $(\mathrm{g} / \mathrm{mL})$ & \begin{tabular}{|l} 
Yield stress \\
$($ dynes/cm
\end{tabular} & $\begin{array}{c}\text { Plastic } \\
\text { viscosity }(\mathrm{cP})\end{array}$ \\
\hline \multirow{4}{*}{ SMP-CWE } & 1 & 28.58 & 1.200 & 183.7 & 9.96 \\
\hline & 4 & 25.57 & 1.177 & 134.7 & 8.19 \\
\hline & 7 & 23.79 & 1.171 & 116.4 & 7.47 \\
\hline & 10 & 22.49 & 1.161 & 104.5 & 7.13 \\
\hline \multirow{4}{*}{ SMP-FFF } & 1 & 27.45 & 1.193 & $\mathrm{~N} / \mathrm{M}$ & $\mathrm{N} / \mathrm{M}$ \\
\hline & 4 & 24.63 & 1.175 & $\mathrm{~N} / \mathrm{M}$ & $\mathrm{N} / \mathrm{M}$ \\
\hline & 7 & 23.55 & 1.170 & $\mathrm{~N} / \mathrm{M}$ & $\mathrm{N} / \mathrm{M}$ \\
\hline & 10 & 22.13 & 1.155 & N/M & N/M \\
\hline \multirow{4}{*}{ SMP-ECR } & 1 & 27.33 & $\mathrm{~N} / \mathrm{M}$ & 181.6 & 9.71 \\
\hline & 4 & 24.67 & $\mathrm{~N} / \mathrm{M}$ & 131.7 & 8.03 \\
\hline & 7 & 23.67 & $\mathrm{~N} / \mathrm{M}$ & 116.9 & 7.55 \\
\hline & 10 & 22.29 & $\mathrm{~N} / \mathrm{M}$ & 99.2 & 7.07 \\
\hline
\end{tabular}


May 2005 SMP Kaolin/Sand Slurry Test

\begin{tabular}{|c|c|c|c|c|c|}
\hline \multirow[b]{2}{*}{ Sample location } & \multirow{2}{*}{$\begin{array}{c}\text { Day } \\
\text { Pulled }\end{array}$} & \multicolumn{4}{|c|}{ Average of Two Measurements } \\
\hline & & wt\% T.S. & Density (g/mL) & $\begin{array}{l}\text { Yield stress } \\
(\text { dynes/cm²) }\end{array}$ & $\begin{array}{c}\text { Plastic } \\
\text { viscosity (cP) }\end{array}$ \\
\hline \multirow{7}{*}{ SMP-CWE } & 1 & 19.87 & 1.134 & 54.0 & 5.32 \\
\hline & 2 & 18.39 & 1.126 & 50.7 & 5.07 \\
\hline & 3 & 18.41 & 1.128 & 53.7 & 5.27 \\
\hline & 4 & 18.36 & 1.128 & 53.1 & 4.99 \\
\hline & 5 & 18.36 & 1.127 & 54.4 & 5.25 \\
\hline & 6 & 17.05 & 1.118 & 43.4 & 4.89 \\
\hline & 7 & 18.24 & 1.127 & 55.7 & 5.25 \\
\hline \multirow{7}{*}{ SMP-FFF } & 1 & 18.67 & 1.129 & 52.5 & 5.42 \\
\hline & 2 & 17.99 & 1.125 & 51.4 & 5.23 \\
\hline & 3 & 18.06 & 1.125 & 53.3 & 5.10 \\
\hline & 4 & 17.92 & 1.124 & 52.5 & 5.16 \\
\hline & 5 & 17.90 & 1.124 & 52.0 & 5.08 \\
\hline & 6 & 16.89 & 1.116 & 43.7 & 4.74 \\
\hline & 7 & 18.12 & 1.126 & 54.9 & 5.35 \\
\hline \multirow{7}{*}{ SMP-ECR } & 1 & 18.65 & 1.131 & 51.6 & 5.14 \\
\hline & 2 & 18.00 & 1.125 & 51.1 & 5.11 \\
\hline & 3 & 18.05 & 1.125 & 52.8 & 5.17 \\
\hline & 4 & 17.96 & 1.124 & 52.5 & 5.20 \\
\hline & 5 & 17.93 & 1.124 & 52.5 & 5.11 \\
\hline & 6 & 19.40 & 1.136 & 68.1 & 5.84 \\
\hline & 7 & 16.98 & 1.117 & 44.3 & 4.91 \\
\hline
\end{tabular}




\section{TABLE OF CONTENTS}

EXECUTIVE SUMMARY iii

LIST OF FIGURES vii

LIST OF TABLES

LIST OF ACRONYMS

1.0 INTRODUCTION AND BACKGROUND

1.1 Weight Percent Total Solids

1.2 Density

1.3 Rheology

1.4 Particle Size Distribution

1.4.1 July 2004 Test Results

1.4.2 September 2004 Test Results

APPENDIX A. Down Flow Curves Fitted To Bingham PlastiC

APPENDIX B. S3000 Particle Size Distributuion 


\section{LIST OF FIGURES}

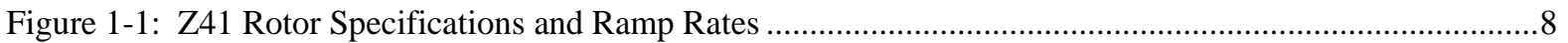

Figure 1-2: Typical Kaolin/Sand Flow Curve of an SMP Sample ........................................................................9

Figure 1-3: Particle Jamming on the Initial Upflow Portion of the Flow Curve ..................................................9

Figure 1-4: ATM Sonic Sifter and Typical PSD of Sand Sample from September 2004 SMP Test....................14

Figure A - 1: Down Flow Curve Sample SMP-CWE-1, July 2004 .....................................................................21

Figure A - 2: Down Flow Curve Sample SMP-CWE-2, July 2004 .................................................................21

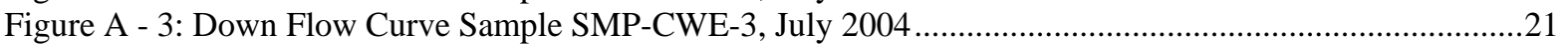

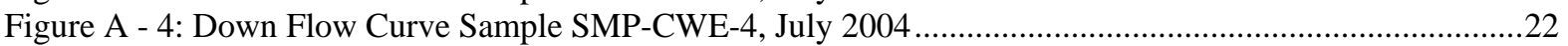

Figure A - 5: Down Flow Curve Sample SMP-CWE-5, July 2004 ..................................................................22

Figure A - 6: Down Flow Curve Sample SMP-CWE-6, July 2004 .................................................................22

Figure A - 7: Down Flow Curve Sample SMP-CWE-7, July 2004 ...................................................................23

Figure A - 8: Down Flow Curve Sample SMP-ECR-3, July 2004 ……...........................................................23

Figure A - 9: Down Flow Curve Sample SMP-ECR-6, July 2004 ……..........................................................23

Figure A - 10: Down Flow Curve Sample SMP-ECR-7, July 2004 .........................................................24

Figure A - 11: Down Flow Curve Sample SMP-CWE-1, September 2004.......................................................24

Figure A - 12: Down Flow Curve Sample SMP-CWE-4, September 2004.......................................................24

Figure A - 13: Down Flow Curve Sample SMP-CWE-7, September 2004.......................................................25

Figure A - 14: Down Flow Curve Sample SMP-CWE-10, September 2004.......................................................25

Figure A - 15: Down Flow Curve Sample SMP-ECR-1, September 2004 ………………....................................25

Figure A - 16: Down Flow Curve Sample SMP-ECR-4, September 2004...........................................................26

Figure A - 17: Down Flow Curve Sample SMP-ECR-7, September 2004......................................................26

Figure A - 18: Down Flow Curve Sample SMP-ECR-10, September 2004........................................................26

Figure A - 19: Down Flow Curve Sample SMP-CWE-1, May 2005 ……..........................................................27

Figure A - 20: Down Flow Curve Sample SMP-CWE-2, May 2005 ..................................................................27

Figure A - 21: Down Flow Curve Sample SMP-CWE-3, May 2005 ……........................................................27

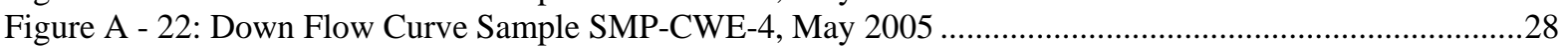

Figure A - 23: Down Flow Curve Sample SMP-CWE-5, May 2005 ……...................................................28

Figure A - 24: Down Flow Curve Sample SMP-CWE-6, May 2005 ..................................................................28

Figure A - 25: Down Flow Curve Sample SMP-CWE-7, May 2005 ..............................................................29

Figure A - 26: Down Flow Curve Sample SMP-FFF-1, May 2005 ..................................................................29

Figure A - 27: Down Flow Curve Sample SMP-FFF-2, May 2005 ..................................................................29

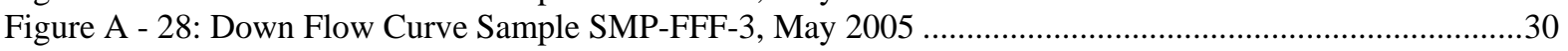

Figure A - 29: Down Flow Curve Sample SMP-FFF-4, May 2005 …..............................................................30

Figure A - 30: Down Flow Curve Sample SMP-FFF-5, May 2005 ....................................................................30

Figure A - 31: Down Flow Curve Sample SMP-FFF-6, May 2005 ....................................................................31

Figure A - 32: Down Flow Curve Sample SMP-FFF-7, May 2005 ..................................................................31

Figure A - 33: Down Flow Curve Sample SMP-ECR-1, May 2005 ……...........................................................31

Figure A - 34: Down Flow Curve Sample SMP-ECR-2, May 2005 ....................................................................32

Figure A - 35: Down Flow Curve Sample SMP-ECR-3, May 2005 .....................................................................32

Figure A - 36: Down Flow Curve Sample SMP-ECR-4, May 2005 .................................................................32

Figure A - 37: Down Flow Curve Sample SMP-ECR-5, May 2005 ……..........................................................33

Figure A - 38: Down Flow Curve Sample SMP-ECR-6, May 2005 ......................................................................33

Figure A - 39: Down Flow Curve Sample SMP-ECR-7, May 2005 ........................................................................33

Figure B - 1: July 2004, SMP-ECR-3 Volume and Number Distribution ...............................................................35

Figure B - 2: July 2004, SMP-FFF-4 Volume and Number Distribution ...........................................................36

Figure B - 3: July 2004, SMP-CWE-4 Volume and Number Distribution .....................................................37

Figure B - 4: July 2004, SMP-ECR-6 Volume and Number Distribution .............................................................38

Figure B - 5: July 2004, SMP-ECR-7 Volume and Number Distribution .............................................................39

Figure B - 6: July 2004, SMP-FFF-7 Volume and Number Distribution ............................................................40 
WSRC-TR-2004-00401

Revision 1

Figure B - 7: July 2004, SMP-CWE-7 Volume and Number Distribution...................................................41

Figure B - 8: September 2004, SMP-ECR-1 Volume and Number Distribution...............................................42

Figure B - 9: September 2004, SMP-FFF-1 Volume and Number Distribution............................................43

Figure B - 10: September 2004, SMP-CWE-1 Volume and Number Distribution..........................................44

Figure B - 11: September 2004, SMP-ECR-4 Volume and Number Distribution..........................................45

Figure B - 12: September 2004, SMP-CWE-4 Volume and Number Distribution...........................................46

Figure B - 13: September 2004, SMP-FFF-4 Volume and Distribution....................................................47

Figure B - 14: September 2004, SMP-ECR-7 Volume and Number Distribution..............................................48

Figure B - 15: September 2004, SMP-CWE-7 Volume and Number Distribution...........................................49

Figure B - 16: September 2004, SMP-FFF-7 Volume and Number Distribution.............................................50

Figure B - 17: September 2004, SMP-ECR-10 Volume and Number Distribution..........................................51

Figure B - 18: September 2004, SMP-CWE-10 Volume and Number Distribution.........................................52

Figure B - 19: September 2004, SMP-FFF-10 Volume and Number Distribution............................................53

Figure B - 20: May 2005, SMP-CWE-1 Volume and Number Distribution ...................................................54

Figure B - 21: May 2005, SMP-FFF-1 Volume and Number Distribution .....................................................55

Figure B - 22: May 2005, SMP-ECR-1 Volume and Number Distribution .................................................56

Figure B - 23: May 2005, SMP-CWE-7 Volume and Number Distribution .................................................57

Figure B - 24: May 2005, SMP-FFF-7 Volume and Number Distribution ....................................................58

Figure B - 25: May 2005, SMP-ECR-7 Volume and Number Distribution ................................................59 


\section{LIST OF TABLES}

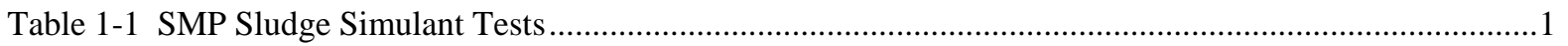

Table 1-2: Analysis Requested of Samples Pulled During the July 2004 Test.....................................................2

Table 1-3: Analyses Requested of Samples Pulled During the September 2004 Test.............................................2

Table 1-4: Analyses Requested of Samples Pulled During the May 2005 Test ....................................................2

Table 1-5: Sample Location and Method of Sampling for the SMP Tests ............................................................

Table 1-6: Kaolin/Sand Weight Percent Total Solids Data for July 2004 Test ......................................................4

Table 1-7: Kaolin/Sand Weight Percent Total Solids Data for September 2004 Test..........................................

Table 1-8: Kaolin/Sand Weight Percent Total Solids Data for May 2005 Test.....................................................5

Table 1-9: Kaolin/Sand Density Data for July 2004 Test...................................................................................

Table 1-10: Kaolin/Sand Density Data for September 2004 Test .......................................................................6

Table 1-11: Kaolin/Sand Density Data for May 2005 Test ...............................................................................

Table 1-12: RS600 Measuring Head Specifications ....................................................................................

Table 1-13: Kaolin/Sand Bingham Plastic Rheological Data for July 2004 Test...............................................10

Table 1-14: Kaolin/Sand Bingham Plastic Rheological Data for September 2004 Test .......................................10

Table 1-15: Kaolin/Sand Bingham Plastic Rheological Data for May 2005 Test .................................................11

Table 1-16: Unimin B-100 Kaolin Particles Size Distribution .............................................................................12

Table 1-17: ASTM Specification for Aggregate (Sand) Used in SMP Test......................................................12

Table 1-18: Particle Size Distribution of Aggregate (Sand) for July 2004 Test ...............................................12

Table 1-19: Mean Volume and Mean Number Particle Size Using Micotrac S3000 for July 2004 Test .............13

Table 1-20: Particle Size Distribution of Sand Used During September 2004 Test .............................................15

Table 1-21: Percent Mass Contribution and PSD of B-100 Kaolin Greater Than 45 Microns.............................15

Table 1-22: Sand Contribution Analyzes From the September 2004 Test .......................................................16

Table 1-23: Mean Volume and Mean Number Particle Size Using Microtrac S3000 for September 2004 Test 16

Table 1-24: Particle Size Distribution of Sand for May 2005 Test ...................................................................17

Table 1-25: Sand Contribution Analyzes for May 2005 Test...............................................................................17

Table 1-26: Mean Volume and Mean Number Particle Size Using Microtrac S3000 For May 2005 Test ..........18 


\section{LIST OF ACRONYMS}

ACTL Aiken County Technology Laboratories

ADS Analytical Developmental Section

CWE Cooling Water Exit

DI De-ionized

ECR Effective Cleaning Radius

FFF Fluid Flow Field

ITS Immobilization Technology Section

NIST National Institute of Standards and Technology

N/M Not Measured

PSD Particle Size Distribution

SMP Submersible Mixer Pump

SRNL Savannah River National Laboratory

TAR Technical Assistance Request

WOW Waste on Wheels

wt\% TS Weight Percent Total Solids 


\subsection{INTRODUCTION AND BACKGROUND}

Waste on Wheels (WOW) engineering requested ${ }^{\mathbf{1}}$ SRNL Immobilization Technology Section (ITS) to perform physical characterization of the kaolin/sand slurries used to characterize the performance of a new SMP. Various tests of the new SMP were performed at the TNX Waste Tank mockup facility from July 2004 to May 2005. In total, four SMPs were tested at various dates as shown in Table 1-1. This table provides a timeline in the operations of the SMPs and the addition of kaolin and sand. The bolded month/year/dates in Table 1-1 are dates when the kaolin/sand slurry samples were pulled, analyzed and the results reported in this report. After completing each test, the contents in the TNX Waste Tank were removed and fresh kaolin and sand were added for the subsequent test.

Table 1-1 SMP Sludge Simulant Tests

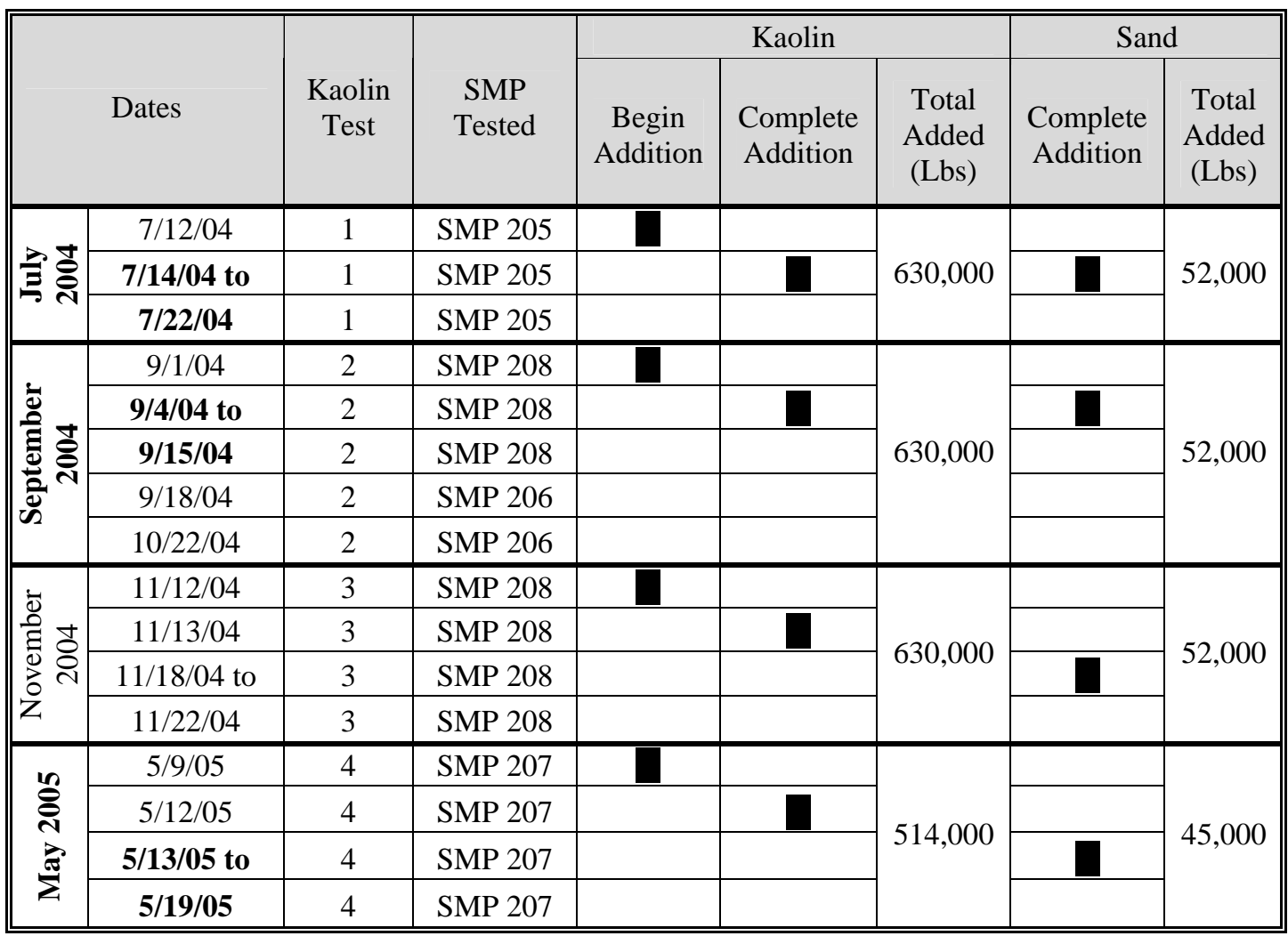

The sample day, sample location, and requested physical property analyses are shown in Table 1-2, Table 1-3, and Table 1-4 for the July 2004, September 2004, and May 2005 tests respectively. 
Table 1-2: Analysis Requested of Samples Pulled During the July 2004 Test

\begin{tabular}{|c|c|c|c|c|c|c|c|c|c|c|c|c|c|c|c|c|c|c|c|c|c|c|}
\hline \multirow{2}{*}{\multicolumn{2}{|c|}{$\begin{array}{l}\text { Day sample pulled } \\
\text { Sample Location }\end{array}$}} & \multicolumn{3}{|c|}{ Day 1} & \multicolumn{3}{|c|}{ Day 2} & \multicolumn{3}{|c|}{ Day 3} & \multicolumn{3}{|c|}{ Day 4} & \multicolumn{3}{|c|}{ Day 5} & \multicolumn{3}{|c|}{ Day 6} & \multicolumn{3}{|c|}{ Day 7} \\
\hline & & $\begin{array}{l}\sum_{3}^{1} \\
3 \\
\sum_{\infty}^{1} \\
\sum_{1}^{1}\end{array}$ & $\sum_{\infty}^{\substack{T\\
}}$ & 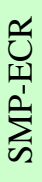 & $\begin{array}{l}\sum_{1}^{1} \\
e_{1}^{1} \\
\sum_{\infty}^{1}\end{array}$ & $\sum_{\substack{\frac{1}{T}\\
}}^{\frac{1}{1}}$ & 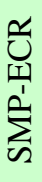 & 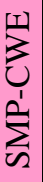 & \begin{tabular}{l}
$\frac{1}{1}$ \\
\multicolumn{1}{|c}{} \\
$\sum_{\infty}^{1}$ \\
$\sum_{\infty}^{1}$
\end{tabular} & 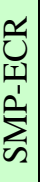 & $\sum_{n}^{1}$ & 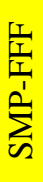 & 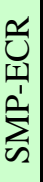 & $\begin{array}{l}\sum_{1}^{1} \\
3 \\
0 \\
\sum_{1}^{1} \\
\sum_{\infty}^{1}\end{array}$ & 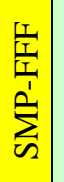 & 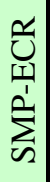 & 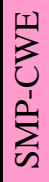 & 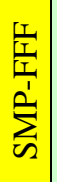 & 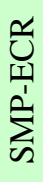 & $\begin{array}{l}\sum_{1}^{1} \\
0 \\
1 \\
\sum_{\infty}^{1}\end{array}$ & 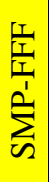 & 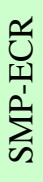 \\
\hline \multirow{4}{*}{ 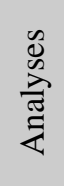 } & Rheology & $\mathrm{X}$ & & & $\mathrm{X}$ & & & X & & X & X & & & X & & & $X$ & & $\mathrm{X}$ & $X$ & & X \\
\hline & Density & $\mathrm{X}$ & $\mathrm{X}$ & & $\mathrm{X}$ & $\mathrm{X}$ & & $\mathrm{X}$ & $\mathrm{X}$ & $\mathrm{X}$ & $\mathrm{X}$ & $\mathrm{X}$ & & $\mathrm{X}$ & $\mathrm{X}$ & & $\mathrm{X}$ & $\mathrm{X}$ & $\mathrm{X}$ & $\mathrm{X}$ & $\mathrm{X}$ & $\mathrm{X}$ \\
\hline & $\mathrm{Wt} \% \mathrm{TS}$ & $\mathrm{X}$ & $\mathrm{X}$ & & $\mathrm{X}$ & $\mathrm{X}$ & & $\mathrm{X}$ & X & X & $\mathrm{X}$ & X & & $\mathrm{X}$ & $\mathrm{X}$ & & $X$ & $\mathrm{X}$ & $\mathrm{X}$ & $\mathrm{X}$ & $\mathrm{X}$ & $\mathrm{X}$ \\
\hline & PSD & & & & & & & & & $\mathrm{X}$ & X & X & & & & & & & $\mathrm{X}$ & $\mathrm{X}$ & $\mathrm{X}$ & $\mathrm{X}$ \\
\hline
\end{tabular}

Blanks mean specified analysis was not requested for this sample.

Table 1-3: Analyses Requested of Samples Pulled During the September 2004 Test

\begin{tabular}{|c|c|c|c|c|c|c|c|c|c|c|c|c|c|}
\hline \multirow{2}{*}{\multicolumn{2}{|c|}{$\begin{array}{l}\text { Day sample pulled } \\
\text { Sample Location }\end{array}$}} & \multicolumn{3}{|c|}{ Day 1} & \multicolumn{3}{|c|}{ Day 4} & \multicolumn{3}{|c|}{ Day 7} & \multicolumn{3}{|c|}{ Day 10} \\
\hline & & $\sum_{\substack{1 \\
1}}^{1}$ & 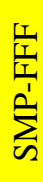 & 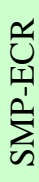 & 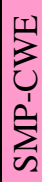 & 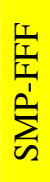 & 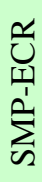 & $\begin{array}{l}\sum_{1}^{1} \\
3 \\
\text { Un } \\
1 \\
\sum_{\infty}^{1}\end{array}$ & $\mid \begin{array}{l}T_{1}^{1} \\
\sum_{1}^{1} \\
\sum_{\infty}^{1} \\
\omega\end{array}$ & 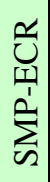 & $\begin{array}{l}\sum_{1}^{1} \\
3 \\
\sum_{1}^{1} \\
\sum_{n}^{1}\end{array}$ & 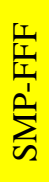 & 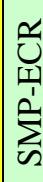 \\
\hline \multirow{5}{*}{ 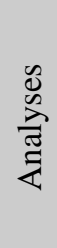 } & Rheology & $\mathrm{X}$ & & $\mathrm{X}$ & $\mathrm{X}$ & & $\mathrm{X}$ & $\mathrm{X}$ & & $\mathrm{X}$ & $\mathrm{X}$ & & $\mathrm{X}$ \\
\hline & Density & $\mathrm{X}$ & $\mathrm{X}$ & & $\mathrm{X}$ & $\mathrm{X}$ & & $\mathrm{X}$ & $\mathrm{X}$ & & $\mathrm{X}$ & $\mathrm{X}$ & \\
\hline & wt $\%$ TS & $\mathrm{X}$ & $\mathrm{X}$ & $\mathrm{X}$ & $\mathrm{X}$ & $\mathrm{X}$ & $\mathrm{X}$ & $*$ & $*$ & * & $\mathrm{X}$ & $\mathrm{X}$ & $\mathrm{X}$ \\
\hline & PSD & $\mathrm{X}$ & $\mathrm{X}$ & $\mathrm{X}$ & $\mathrm{X}$ & $\mathrm{X}$ & $\mathrm{X}$ & $\mathrm{X}$ & $\mathrm{X}$ & $\mathrm{X}$ & $\mathrm{X}$ & $\mathrm{X}$ & $\mathrm{X}$ \\
\hline & Sand Contribution & & & & $\mathrm{X}$ & $\mathrm{X}$ & $\mathrm{X}$ & $\mathrm{X}$ & $\mathrm{X}$ & $\mathrm{X}$ & $\mathrm{X}$ & $\mathrm{X}$ & $\mathrm{X}$ \\
\hline
\end{tabular}

Blanks mean specified analysis was not requested for this sample.

* Sample analyzed for wt\% TS. Data used to determine sand contribution.

Table 1-4: Analyses Requested of Samples Pulled During the May 2005 Test

\begin{tabular}{|c|c|c|c|c|c|c|c|c|c|c|c|c|c|c|c|c|c|c|c|c|c|c|}
\hline & Day sample pulled & & Day & & & Day & & & ay 3 & & & ay 4 & & & ay 5 & & & ay $\epsilon$ & & & ay 7 & \\
\hline & Sample Location & 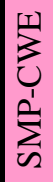 & 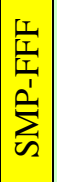 & $\begin{array}{l}\stackrel{n}{u} \\
\sum_{n=1}^{1} \\
\stackrel{1}{1}\end{array}$ & 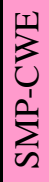 & 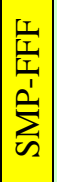 & 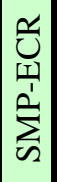 & 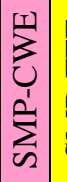 & 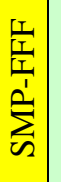 & 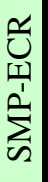 & $\begin{array}{l}\sum_{3}^{1} \\
u_{1} \\
\sum_{\infty}^{1}\end{array}$ & 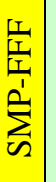 & 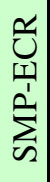 & $\begin{array}{l}y_{1}^{1} \\
3 \\
u \\
\sum_{\omega}^{1} \\
\stackrel{1}{1}\end{array}$ & 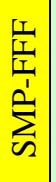 & 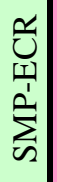 & 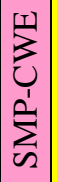 & 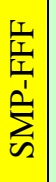 & 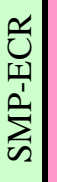 & 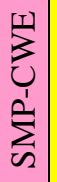 & 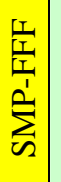 & \\
\hline & Rheology & $\Lambda$ & $\mathrm{X}$ & $\mathrm{X}$ & $\mathrm{X}$ & $\mathrm{X}$ & $\mathrm{X}$ & $\mathrm{X}$ & $\mathrm{X}$ & $\mathrm{X}$ & $\mathrm{X}$ & $\mathrm{X}$ & $\mathrm{X}$ & $\mathrm{X}$ & $\mathrm{X}$ & $\mathrm{X}$ & $\mathrm{X}$ & $\mathrm{X}$ & $\mathrm{X}$ & $\mathrm{X}$ & $\mathrm{X}$ & $\mathrm{X}$ \\
\hline & Density & $\mathrm{X}$ & $\mathrm{X}$ & $\mathrm{X}$ & $\mathrm{X}$ & $\mathrm{X}$ & $\mathrm{X}$ & $\mathrm{X}$ & $\mathrm{X}$ & $\mathrm{X}$ & $\mathrm{X}$ & $X$ & $\mathrm{X}$ & $X$ & $\mathrm{X}$ & $\mathrm{X}$ & $\mathrm{X}$ & $\mathrm{X}$ & $\mathrm{X}$ & $\mathrm{X}$ & $\mathrm{X}$ & $\mathrm{X}$ \\
\hline$\vec{\beth}$ & $\mathrm{wt} \% \mathrm{TS}$ & $\mathrm{X}$ & $X$ & $X$ & $X$ & $X$ & $\mathrm{X}$ & $\mathrm{X}$ & $\mathrm{X}$ & $\mathrm{X}$ & $\mathrm{X}$ & $\mathrm{X}$ & $\mathrm{X}$ & $\mathrm{X}$ & $\mathrm{X}$ & $\mathrm{X}$ & $\mathrm{X}$ & $X$ & $\mathrm{X}$ & $\mathrm{X}$ & $\mathrm{X}$ & $\mathrm{X}$ \\
\hline & PSD & $\mathrm{X}$ & $\mathrm{X}$ & $\mathrm{X}$ & & & & & & & & & & & & & & & & $\mathrm{X}$ & $X$ & $\mathrm{X}$ \\
\hline & Sand Contribution & $\mathrm{X}$ & $\mathrm{X}$ & $\mathrm{X}$ & $\mathrm{X}$ & $\mathrm{X}$ & $\mathrm{X}$ & & & & & & & & & & & & & $\mathrm{X}$ & $\mathrm{X}$ & \\
\hline
\end{tabular}

Blanks mean specified analysis was not requested for this sample. 
The locations and method of sampling at each location is provided in Table 1-5. A $400 \mathrm{~mL}$ sample at each sample location per day was required to complete the necessary physical characterization. For the sand contribution analysis, an additional $400 \mathrm{~mL}$ or $2000 \mathrm{~L}$ samples were pulled.

Table 1-5: Sample Location and Method of Sampling for the SMP Tests

\begin{tabular}{|c|l||}
\hline \hline Location & \multicolumn{1}{|c|}{ Sampling Method } \\
\hline $\begin{array}{c}\text { SMP - Cooling Water } \\
\text { Exit (CWE) }\end{array}$ & $\begin{array}{l}\text { Originally there were four discharge motor cooling streams leaving the motor housing. } \\
\text { Results of early testing reduced that number to two. A clean stainless steel beaker was } \\
\text { used to gather a sample from the discharge and the sample(s) poured into a sample } \\
\text { bottle. The sample cup was wetted with the CWE prior to sampling. }\end{array}$ \\
\hline $\begin{array}{c}\text { SMP - Fluid Flow Field } \\
\text { (FFF) }\end{array}$ & $\begin{array}{l}\text { A pump was used to pull a sample from the discharge of the rotating SMP. The sample } \\
\text { was pulled two feet from the bottom of the tank when the jet rotated into the sampling } \\
\text { location. }\end{array}$ \\
\hline $\begin{array}{c}\text { SMP - Effective } \\
\text { Cleaning Radius (ECR) }\end{array}$ & $\begin{array}{l}\text { A dip sample (1 to 3 feet deep) was collected from a stagnant zone near the edge of the } \\
\text { tank opposite of the SMP. }\end{array}$ \\
\hline \hline
\end{tabular}

Once the samples were received at SRNL, samples that required PSD analysis were pulled and delivered to the Analytical Development Section (ADS) for analysis. The remaining analyses occurred at Aiken County Technology Laboratories (ACTL). Prior to pulling the sample for analysis, the sample bottles were homogenized. The following sections describe the methods used to perform the various analyses, the results, and conclusions.

\subsection{Weight Percent Total Solids}

Weight percent total solids (wt\% TS) were performed using a Mettler Toledo HR83 Halogen Moisture analyzer. This moisture analyzer uses a load cell that continuously measures the mass of the sample during the measurement. The moisture is driven off using a halogen heat lamp that is controlled by an infrared thermometer. The mass of a sample pan is first measured and the weight tarred. Approximately a 1.5 to 3 gram sub-sample of the kaolin/sand sample is placed onto the sample pan and this mass is recorded by the analyzer. The temperature of the sample is then ramped to $105^{\circ} \mathrm{C}$ and maintained at $105^{\circ} \mathrm{C}$ throughout the measurement. The measurement stops when the weight of the sample does not change more than 1 milligram over a 20 second period and this final mass is recorded by the analyzer. The $\mathrm{wt} \%$ TS is then determined by taking the ratio of the final mass to initial mass and multiplying this value by $100 \%$. The analyzer load cell is checked on a daily basis (when used) using a 2.0 gram weight and functionally checked using a $7.0 \mathrm{wt} \% \mathrm{TS} \mathrm{NaOH}$ solution.

For each sample that required wt $\%$ TS measurements, two replicates were analyzed. The individual results, average and percent standard deviation are shown in Table 1-6, Table 1-7, and Table 1-8 for the July 2004, September 2004 and May 2005 tests respectively. There were no limits provided in the TAR stating the range in which the wt\% TS must be. The SMP procurement specification ${ }^{2}$ states wt\% solids range of 0 to $17 \%$ (section 3.3.1.1) for tank environmental conditions and a $20 \mathrm{wt} \%$ TS (section 4.1.3) for SMP acceptance testing. In the first two tests (Table 1-6 and Table 1-7), the wt\% TS of the kaolin/sand slurries exceeded these limits. In the third test (May 2005, Table 1-8), the wt\% solids were within the wt\% TS limits. The data does reveal that samples pulled on the same day, the CWE samples are slightly higher in wt\% TS as compared to the FFF and ECR samples. The FFF and ECR samples pulled on the same days have similar wt\% TS results.

\footnotetext{
${ }^{2}$ M-SPP-G-00302, “Procurement Specification - Submersible Mixer Pump”, Rev. 1, May 23, 2003
} 
Table 1-6: Kaolin/Sand Weight Percent Total Solids Data for July 2004 Test

\begin{tabular}{|c|c|c|c|c|c|}
\hline \multirow[b]{2}{*}{ Sample location } & \multirow{2}{*}{$\begin{array}{c}\text { Day } \\
\text { Pulled }\end{array}$} & \multicolumn{4}{|c|}{ Weight Percent Total Solids } \\
\hline & & Sample 1 & Sample 2 & Average & $\begin{array}{c}\text { \% standard } \\
\text { deviation }\end{array}$ \\
\hline \multirow{7}{*}{ SMP-CWE } & 1 & 25.25 & 25.08 & 25.17 & $0.48 \%$ \\
\hline & 2 & 24.03 & 24.04 & 24.04 & $0.03 \%$ \\
\hline & 3 & 23.80 & 23.91 & 23.86 & $0.33 \%$ \\
\hline & 4 & 23.84 & 23.94 & 23.89 & $0.30 \%$ \\
\hline & 5 & 22.93 & 23.08 & 23.01 & $0.46 \%$ \\
\hline & 6 & 22.90 & 23.13 & 23.02 & $0.71 \%$ \\
\hline & 7 & 23.29 & 23.17 & 23.23 & $0.37 \%$ \\
\hline \multirow{7}{*}{ SMP-FFF } & 1 & 24.22 & 24.42 & 24.32 & $0.58 \%$ \\
\hline & 2 & 23.84 & 23.60 & 23.72 & $0.72 \%$ \\
\hline & 3 & 23.48 & 23.49 & 23.49 & $0.03 \%$ \\
\hline & 4 & 23.44 & 23.38 & 23.41 & $0.18 \%$ \\
\hline & 5 & 22.71 & 22.82 & 22.77 & $0.34 \%$ \\
\hline & 6 & 22.81 & 22.56 & 22.69 & $0.78 \%$ \\
\hline & 7 & 22.90 & 22.94 & 22.92 & $0.12 \%$ \\
\hline \multirow{3}{*}{ SMP-ECR } & 3 & 23.58 & 23.44 & 23.51 & $0.42 \%$ \\
\hline & 6 & 22.13 & 21.99 & 22.06 & $0.45 \%$ \\
\hline & 7 & 22.93 & 23.01 & 22.97 & $0.25 \%$ \\
\hline
\end{tabular}

Table 1-7: Kaolin/Sand Weight Percent Total Solids Data for September 2004 Test

\begin{tabular}{||c|c|c|c|c|c||}
\hline \multirow{3}{*}{ Sample location } & \multirow{2}{*}{$\begin{array}{c}\text { Day } \\
\text { Pulled }\end{array}$} & \multicolumn{4}{|c||}{ Weight Percent Total Solids } \\
\cline { 3 - 6 } & & Sample 1 & Sample 2 & Average & $\begin{array}{c}\text { \% standard } \\
\text { deviation }\end{array}$ \\
\hline \multirow{3}{*}{ SMP-CWE } & 1 & 28.31 & 28.85 & 28.58 & $1.34 \%$ \\
\cline { 2 - 6 } & 4 & 25.74 & 25.40 & 25.57 & $0.94 \%$ \\
\cline { 2 - 6 } & 7 & 23.83 & 23.74 & 23.79 & $0.27 \%$ \\
\cline { 2 - 6 } & 10 & 22.80 & 22.81 & 22.81 & $0.03 \%$ \\
\hline \multirow{3}{*}{ SMP-FFF } & 1 & 27.74 & 27.16 & 27.45 & $1.49 \%$ \\
\cline { 2 - 6 } & 4 & 24.53 & 24.73 & 24.63 & $0.57 \%$ \\
\cline { 2 - 6 } & 7 & 23.65 & 23.44 & 23.55 & $0.63 \%$ \\
\cline { 2 - 6 } & 10 & 22.12 & 22.13 & 22.13 & $0.03 \%$ \\
\hline \multirow{3}{*}{ SMP-ECR } & 1 & 27.55 & 27.10 & 27.33 & $1.16 \%$ \\
\cline { 2 - 6 } & 4 & 24.60 & 24.74 & 24.67 & $0.40 \%$ \\
\cline { 2 - 6 } & 7 & 23.69 & 23.64 & 23.67 & $0.15 \%$ \\
\cline { 2 - 6 } & 10 & 22.27 & 22.31 & 22.29 & $0.13 \%$ \\
\hline
\end{tabular}


Table 1-8: Kaolin/Sand Weight Percent Total Solids Data for May 2005 Test

\begin{tabular}{||c|c|c|c|c|c||}
\hline \multirow{3}{*}{ Sample location } & \multirow{2}{*}{$\begin{array}{c}\text { Day } \\
\text { Pulled }\end{array}$} & \multicolumn{4}{|c|}{ Weight Percent Total Solids } \\
\cline { 2 - 6 } & Sample 1 & Sample 2 & Average & $\begin{array}{c}\text { \% standard } \\
\text { deviation }\end{array}$ \\
\hline \multirow{5}{*}{ SMP-CWE } & 1 & 19.78 & 19.96 & 19.87 & $0.64 \%$ \\
\cline { 2 - 6 } & 2 & 18.37 & 18.41 & 18.39 & $0.15 \%$ \\
\cline { 2 - 6 } & 3 & 18.41 & 18.41 & 18.41 & $0.00 \%$ \\
\cline { 2 - 6 } & 4 & 18.29 & 18.42 & 18.36 & $0.50 \%$ \\
\cline { 2 - 6 } & 5 & 18.34 & 18.37 & 18.36 & $0.12 \%$ \\
\cline { 2 - 6 } & 6 & 17.00 & 17.09 & 17.05 & $0.37 \%$ \\
\cline { 2 - 6 } & 7 & 18.26 & 18.21 & 18.24 & $0.19 \%$ \\
\hline \multirow{5}{*}{ SMP-FFF } & 1 & 18.61 & 18.72 & 18.67 & $0.42 \%$ \\
\cline { 2 - 6 } & 2 & 18.01 & 17.96 & 17.99 & $0.20 \%$ \\
\cline { 2 - 6 } & 3 & 18.04 & 18.07 & 18.06 & $0.12 \%$ \\
\cline { 2 - 6 } & 4 & 17.90 & 17.94 & 17.92 & $0.16 \%$ \\
\cline { 2 - 6 } & 5 & 17.85 & 17.95 & 17.90 & $0.40 \%$ \\
\cline { 2 - 6 } & 6 & 16.82 & 16.95 & 16.89 & $0.54 \%$ \\
\cline { 2 - 6 } & 7 & 18.15 & 18.08 & 18.12 & $0.27 \%$ \\
\hline & 1 & 18.70 & 18.59 & 18.65 & $0.42 \%$ \\
\cline { 2 - 6 } & 2 & 17.98 & 18.01 & 18.00 & $0.12 \%$ \\
\cline { 2 - 6 } & 3 & 18.05 & 18.05 & 18.05 & $0.00 \%$ \\
\cline { 2 - 6 } & 4 & 17.94 & 17.98 & 17.96 & $0.16 \%$ \\
\cline { 2 - 6 } & 5 & 17.91 & 17.95 & 17.93 & $0.16 \%$ \\
\hline SMP-ECR & 6 & 19.33 & 19.46 & 19.40 & $0.47 \%$ \\
\hline 7 & 16.94 & 17.02 & 16.98 & $0.33 \%$ \\
\hline
\end{tabular}

\subsection{Density}

Densities were performed using an Anton Paar DMA 4500 Density analyzer. A sample is pushed into the density analyzer u-tube and the sample temperature controlled to $25^{\circ} \mathrm{C}$. A vibration is then induced on one end of the u-tube and the frequency is measured at the other end. The density of the sample is determined on the measured frequency. The density analyzer is functionally checked on a daily basis (when used) with DI water.

For each sample that required density measurements, two replicates were analyzed. The individual results, average and percent standard deviation are shown in Table 1-9, Table 1-10 and Table 1-11 for the July 2004, September 2004 and May 2005 tests respectively. Specific gravity testing limits provided in the SMP procurement specification ranged from 1.0 to 1.5 (section 3.3.1.1) ${ }^{2}$ for the supernatant but also specified testing the SMP using a kaolin slurry with a specific gravity of 1.14 (see page 14$)^{3}$ for acceptance testing. The density of the kaolin/sand slurry samples were above the specific gravity of the kaolin slurry for acceptance testing for the July 2004 and September 2004 tests. For the May 2005 test, the specific gravity was slightly less than 1.14. The data reveals that for samples pulled on the same day, the CWE samples have a higher density as compared to the FFF and ECR samples and this is supported by the wt\% TS data. The FFF and ECR samples pulled on the same day have similar density results.

\footnotetext{
${ }^{3}$ M-DCF-F-03629
} 
Table 1-9: Kaolin/Sand Density Data for July 2004 Test

\begin{tabular}{||c|c|c|c|c|c||}
\hline \multirow{3}{*}{ Sample location } & \multirow{2}{*}{$\begin{array}{c}\text { Day } \\
\text { Pulled }\end{array}$} & \multicolumn{4}{|c|}{ Density (g/mL) } \\
\cline { 2 - 6 } & Sample 1 & Sample 2 & Average & $\begin{array}{c}\text { \% standard } \\
\text { deviation }\end{array}$ \\
\hline \multirow{5}{*}{ SMP-CWE } & 1 & 1.180 & 1.180 & 1.180 & $0.02 \%$ \\
\cline { 2 - 6 } & 2 & 1.171 & 1.171 & 1.171 & $0.01 \%$ \\
\cline { 2 - 6 } & 3 & 1.171 & 1.171 & 1.171 & $0.00 \%$ \\
\cline { 2 - 6 } & 4 & 1.173 & 1.173 & 1.173 & $0.00 \%$ \\
\cline { 2 - 6 } & 5 & 1.165 & 1.165 & 1.165 & $0.00 \%$ \\
\cline { 2 - 6 } & 6 & 1.164 & 1.164 & 1.164 & $0.00 \%$ \\
\hline \multirow{5}{*}{ SMP-FFF } & 7 & 1.167 & 1.167 & 1.167 & $0.01 \%$ \\
\hline & 1 & 1.177 & 1.177 & 1.177 & $0.00 \%$ \\
\cline { 2 - 6 } & 2 & 1.167 & 1.167 & 1.167 & $0.00 \%$ \\
\cline { 2 - 6 } & 3 & 1.165 & 1.165 & 1.165 & $0.00 \%$ \\
\cline { 2 - 6 } & 4 & 1.169 & 1.169 & 1.169 & $0.00 \%$ \\
\cline { 2 - 6 } & 6 & 1.162 & 1.162 & 1.162 & $0.01 \%$ \\
\cline { 2 - 6 } & 7 & 1.161 & 1.161 & 1.161 & $0.01 \%$ \\
\hline \multirow{5}{*}{ SMP-ECR } & 3 & 1.168 & 1.164 & 1.164 & $0.00 \%$ \\
\cline { 2 - 6 } & 6 & 1.157 & 1.157 & 1.157 & $0.01 \%$ \\
\cline { 2 - 6 } & 7 & 1.165 & 1.165 & 1.165 & $0.00 \%$ \\
\hline \hline
\end{tabular}

Table 1-10: Kaolin/Sand Density Data for September 2004 Test

\begin{tabular}{||c|c|c|c|c|c||}
\hline \multirow{3}{*}{ Sample location } & \multirow{2}{*}{$\begin{array}{c}\text { Day } \\
\text { Pulled }\end{array}$} & \multicolumn{4}{|c|}{ Density (g/mL) } \\
\cline { 3 - 6 } & Sample 1 & Sample 2 & Average & $\begin{array}{c}\text { \% standard } \\
\text { deviation }\end{array}$ \\
\hline \multirow{3}{*}{ SMP-CWE } & 1 & 1.202 & 1.198 & 1.200 & $0.24 \%$ \\
\cline { 2 - 6 } & 4 & 1.177 & 1.178 & 1.177 & $0.01 \%$ \\
\cline { 2 - 6 } & 7 & 1.171 & 1.171 & 1.171 & $0.00 \%$ \\
\cline { 2 - 6 } & 10 & 1.161 & 1.161 & 1.161 & $0.00 \%$ \\
\hline \multirow{3}{*}{ SMP-FFF } & 1 & 1.193 & 1.193 & 1.193 & $0.00 \%$ \\
\cline { 2 - 6 } & 4 & 1.175 & 1.175 & 1.175 & $0.01 \%$ \\
\cline { 2 - 6 } & 7 & 1.170 & 1.170 & 1.170 & $0.00 \%$ \\
\cline { 2 - 6 } & 10 & 1.155 & 1.155 & 1.155 & $0.00 \%$ \\
\hline
\end{tabular}


Table 1-11: Kaolin/Sand Density Data for May 2005 Test

\begin{tabular}{|c|c|c|c|c|c|}
\hline \multirow[b]{2}{*}{ Sample location } & \multirow{2}{*}{$\begin{array}{l}\text { Day } \\
\text { Pulled }\end{array}$} & \multicolumn{4}{|c|}{ Density (g/mL) } \\
\hline & & Sample 1 & Sample 2 & Average & $\begin{array}{c}\% \text { standard } \\
\text { deviation }\end{array}$ \\
\hline \multirow{7}{*}{ SMP-CWE } & 1 & 1.134 & 1.134 & 1.134 & $0.00 \%$ \\
\hline & 2 & 1.126 & 1.126 & 1.126 & $0.00 \%$ \\
\hline & 3 & 1.128 & 1.128 & 1.128 & $0.00 \%$ \\
\hline & 4 & 1.128 & 1.128 & 1.128 & $0.00 \%$ \\
\hline & 5 & 1.127 & 1.127 & 1.127 & $0.01 \%$ \\
\hline & 6 & 1.118 & 1.118 & 1.118 & $0.00 \%$ \\
\hline & 7 & 1.127 & 1.127 & 1.127 & $0.01 \%$ \\
\hline \multirow{7}{*}{ SMP-FFF } & 1 & 1.129 & 1.129 & 1.129 & $0.00 \%$ \\
\hline & 2 & 1.125 & 1.125 & 1.125 & $0.01 \%$ \\
\hline & 3 & 1.125 & 1.125 & 1.125 & $0.00 \%$ \\
\hline & 4 & 1.124 & 1.124 & 1.124 & $0.00 \%$ \\
\hline & 5 & 1.124 & 1.124 & 1.124 & $0.01 \%$ \\
\hline & 6 & 1.116 & 1.116 & 1.116 & $0.00 \%$ \\
\hline & 7 & 1.126 & 1.126 & 1.126 & $0.00 \%$ \\
\hline \multirow{7}{*}{ SMP-ECR } & 1 & 1.131 & 1.131 & 1.131 & $0.00 \%$ \\
\hline & 2 & 1.125 & 1.125 & 1.125 & $0.00 \%$ \\
\hline & 3 & 1.125 & 1.125 & 1.125 & $0.00 \%$ \\
\hline & 4 & 1.124 & 1.124 & 1.124 & $0.00 \%$ \\
\hline & 5 & 1.124 & 1.124 & 1.124 & $0.00 \%$ \\
\hline & 6 & 1.136 & 1.136 & 1.136 & $0.00 \%$ \\
\hline & 7 & 1.117 & 1.117 & 1.117 & $0.01 \%$ \\
\hline
\end{tabular}

\subsection{Rheology}

A Haake RS 600 rheometer was used for all rheological measurements performed in this task. Published RS600 specifications are shown in Table 1-12. The samples for rheological measurements were shaken for at least 1 minute prior to the initial measurement and the sample was shaken for at least 30 seconds prior to the second measurement.

Table 1-12: RS600 Measuring Head Specifications

\begin{tabular}{|c|c|c|}
\hline Specification & Units & Value \\
\hline Maximum Torque & $\mathrm{N}-\mathrm{m}$ & $0.5 \times 10^{-7}$ \\
\hline Minimum Torque (recommended) & $\mathrm{N}-\mathrm{m}$ & 0.2 \\
\hline Maximum Speed & RPM & 1500 \\
\hline Minimum Speed & RPM & 0.001 \\
\hline
\end{tabular}

Flow curve measurements were obtained using a (Z41) cylindrical rotor and its corresponding cup. The design is shown in Figure 1-1. The Z41 rotor is initially installed onto the RS600 and a zero reference point is determined by the rheometer. The Z41 rotor is then removed. A homogenized sample is placed into the appropriate cup and lowered into a temperature/controlled cup holder, which controlled the 
temperature of the sample at $25^{\circ} \mathrm{C}$. The RS600 rheometer can control the rate at which the rotor spins and measures both the rotational speed and the torque (the resistance to shear). The shear stress at the wall of the rotating rotor is then calculated (internally by the Haake software) based on the product of the measured torque and geometry (A-factor) of the rotor. The shear rate of the rotating rotor is calculated as the product of the measured speed and geometry (M-factor, assumes fluid is Newtonian) of the rotor. The A-factor, M-factor, shear rate range and the ramp up time, hold time at maximum shear rate, and ramp down time are provided in Figure 1-1.

\begin{tabular}{|c|c|c|}
\hline Design of Rotor & \multicolumn{2}{|c|}{ Z41 Rotor } \\
\hline \multirow{10}{*}{$\frac{\mathrm{Ra}}{\mathrm{Ri}}$} & Rotor radius (mm) & $\mathrm{R}_{\mathrm{i}}=20.7$ \\
\hline & Cup Radius (mm) & $\mathrm{R}_{\mathrm{a}}=21.7$ \\
\hline & Height of rotor (mm) & $\mathrm{L}=55$ \\
\hline & Sample Volume $\left(\mathrm{cm}^{3}\right)$ & $V=15$ \\
\hline & A factor $(\mathrm{Pa} /(\mathrm{N} \cdot \mathrm{m}))$ & 6750 \\
\hline & $\mathrm{M}$ factor $\left(\mathrm{s}^{-1} /\left(\mathrm{rad} \cdot \mathrm{s}^{-1}\right)\right)$ & 22.40 \\
\hline & Measuring Range $\left(\mathrm{s}^{-1}\right)$ & $0-1000$ \\
\hline & Ramp up time (min) & 5 \\
\hline & Hold time (min) & 1 \\
\hline & Ramp down time (min) & 5 \\
\hline
\end{tabular}

Figure 1-1: Z41 Rotor Specifications and Ramp Rates

Prior to performing any flow curve measurement, the rotor and cup are inspected for visual damage that could potentially impact the flow measurement. A National Institute of Standards and Technology (NIST) traceable Newtonian oil standard was then used to verify the operability of the RS600 at a measurement temperature of $25^{\circ} \mathrm{C}$ prior to starting any rheological work related to the kaolin/sand samples.

For each sample that required rheology, two replicates were analyzed. A typical flow curve is shown in Figure 1-2. Inspection of this flow curve shows that the down curves were better defined at the lower shear rates and were slightly more viscous than the up curve; hence the down curves were selected as the curve to be analyzed for all samples. There is however, very little difference between the up and down curves. Additionally, while performing the September test flow curves, slight jamming was noticed (due to larger particles), but their impact on the flow curves were minimal, after the particles were sheared or dropped out of the shearing zone between the bob and cup. This is shown in Figure 1-3, where after the initial jamming, the up and down curve lay on top of each other. The jamming was not observed in any of the July 2004 flow curves and was not evident in all the September 2004 flow curves. Additionally, the results between two flow curves for a given samples showed good agreement. 


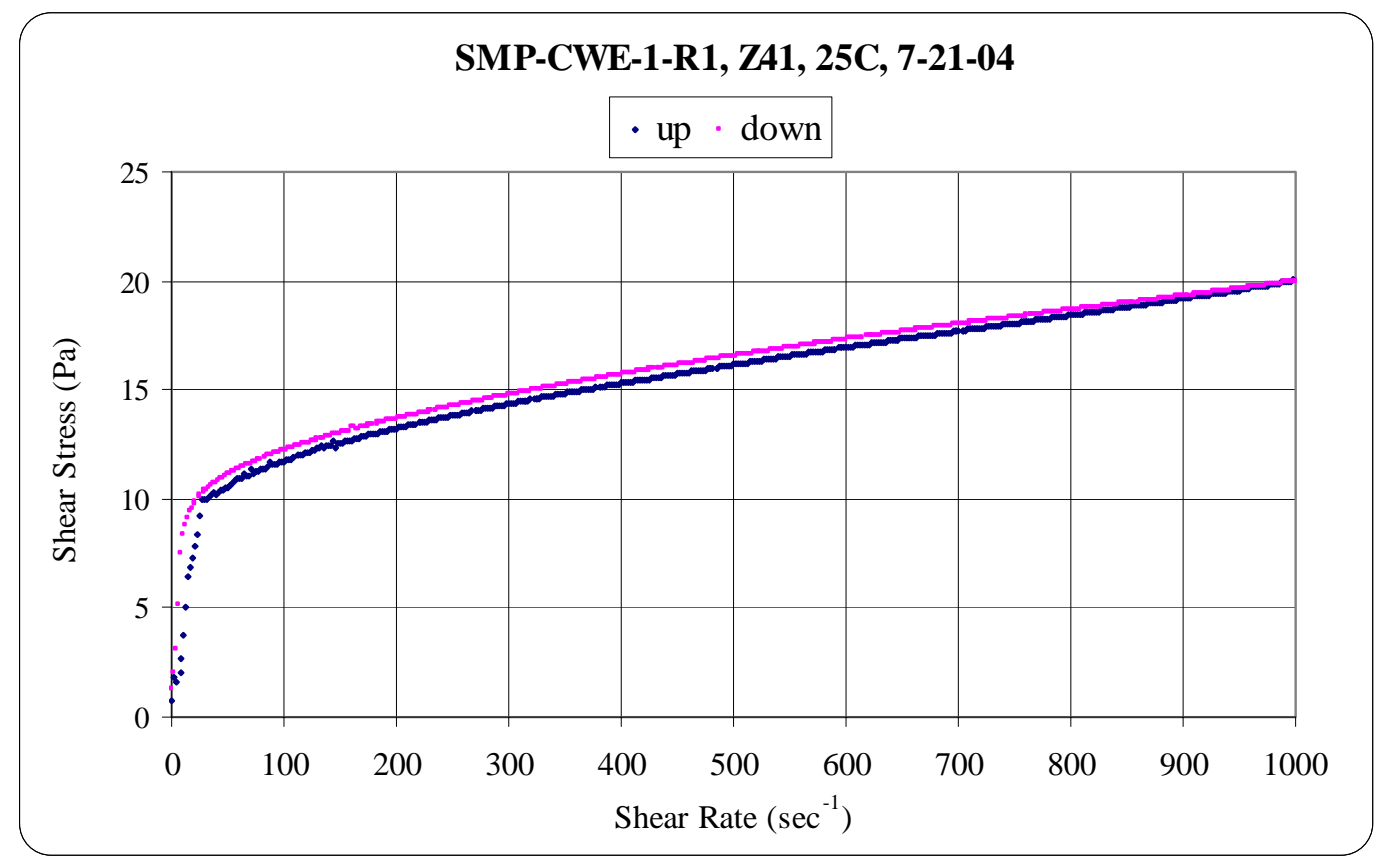

Figure 1-2: Typical Kaolin/Sand Flow Curve of an SMP Sample

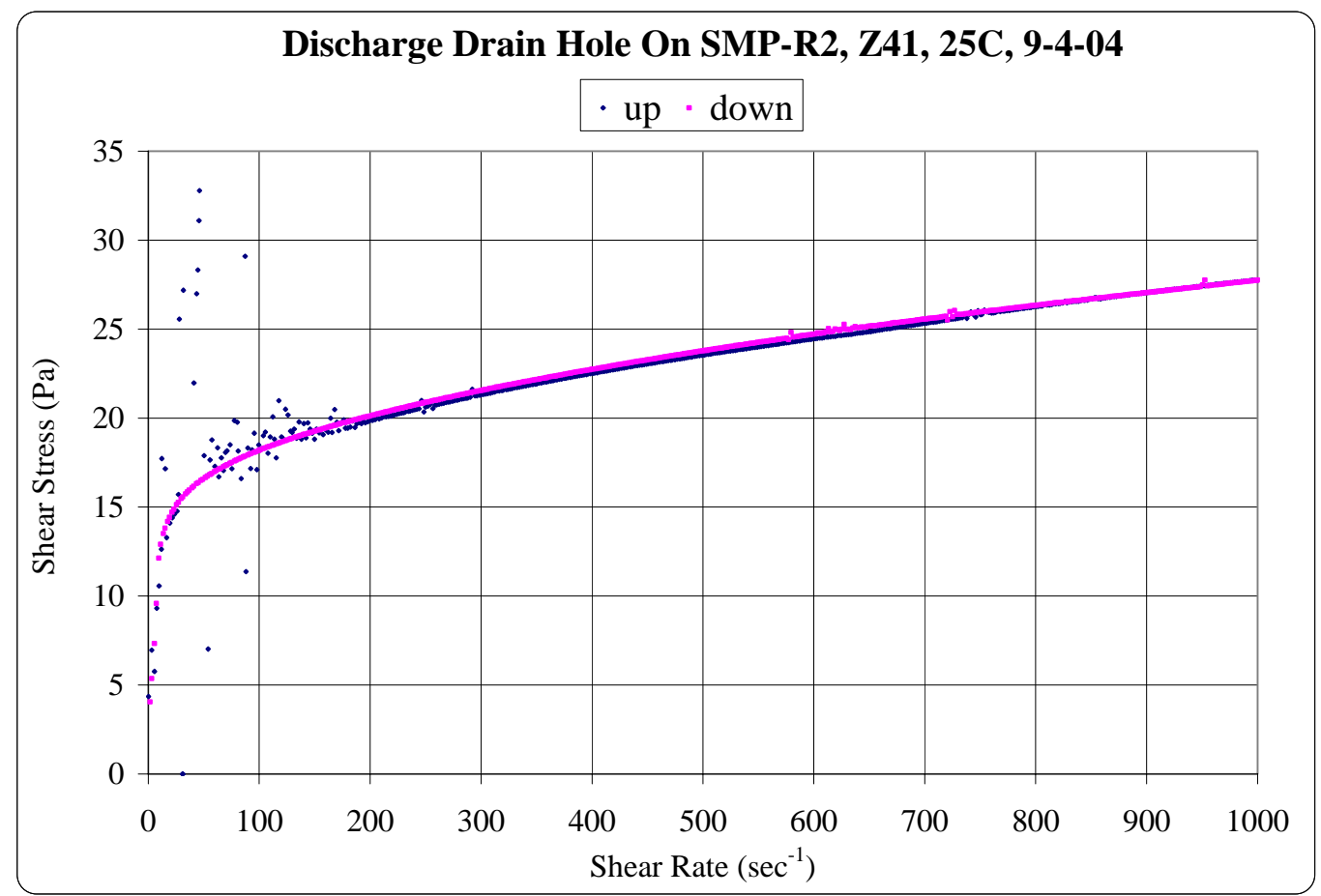

Figure 1-3: Particle Jamming on the Initial Upflow Portion of the Flow Curve

The down curves were analyzed as a Bingham Plastic fluid (equation 1-1) and the Bingham Plastic fits are shown in Appendix A for each sample analyzed. All flow curves were fitted between a shear rate of $100 \mathrm{sec}^{-1}$ to $1000 \mathrm{sec}^{-1}$. The down curve results for the Bingham Plastic yield stress and plastic viscosity include the individual measurements, average and percent standard deviation, and are summarized in 
Table 1-13, Table 1-14, and Table 1-15 for the July 2004, September 2004 and May 2005 tests respectively. Limits provided in the TAR as well as in the procurement specification ${ }^{2}$ for the Bingham Plastic parameters were 10 to 300 dynes $/ \mathrm{cm}^{2}$ for the yield stress and 3 to $50 \mathrm{cP}$ for the plastic viscosity. In all cases, the kaolin/sand slurry samples Bingham Plastic yield stresses and plastic viscosities were within the procurement specifications, but below 50\% of the maximum yield stress and plastic viscosity values. The Bingham Plastic properties for the May 2005 test were much lower than those of the previous two tests.

$$
\tau=\tau_{B P}+\eta_{B P} \cdot \dot{\gamma}
$$

Where: $\tau=$ shear stress $(\mathrm{Pa})\left\{\right.$ Note $1 \mathrm{~Pa}=10$ dynes $\left./ \mathrm{cm}^{2}\right\}$

$\dot{\gamma}=$ shear rate $\left(\sec ^{-1}\right)$

$\tau_{\mathrm{BP}}=$ Bingham Plastic yield stress $(\mathrm{Pa})$

$\eta_{\mathrm{BP}}=$ Bingham Plastic Viscosity (Pa·s) $\{$ Note $1 \mathrm{~m}$ Pa·s $=1$ centipoise $\}$

Table 1-13: Kaolin/Sand Bingham Plastic Rheological Data for July 2004 Test

\begin{tabular}{|c|c|c|c|c|c|c|c|c|c|}
\hline \multirow{2}{*}{$\begin{array}{l}\text { Sample } \\
\text { location }\end{array}$} & \multirow{2}{*}{$\begin{array}{l}\text { Day } \\
\text { Pulled }\end{array}$} & \multicolumn{4}{|c|}{ Yield Stress (dynes/ $/ \mathrm{cm}^{2}$ ) } & \multicolumn{4}{|c|}{ Plastic Viscosity (cP) } \\
\hline & & Sample 1 & Sample 2 & Average & $\begin{array}{c}\text { \% standard } \\
\text { deviation }\end{array}$ & Sample 1 & Sample 2 & Average & $\begin{array}{l}\text { \% standard } \\
\text { deviation }\end{array}$ \\
\hline \multirow{7}{*}{ SMP-CWE } & 1 & 122.4 & 121.7 & 122.0 & $0.38 \%$ & 8.09 & 7.98 & 8.04 & $0.95 \%$ \\
\hline & 2 & 108.6 & 107.1 & 107.9 & $0.97 \%$ & 7.58 & 7.46 & 7.52 & $1.07 \%$ \\
\hline & 3 & 108.7 & 106.6 & 107.6 & $1.37 \%$ & 7.47 & 7.38 & 7.43 & $0.80 \%$ \\
\hline & 4 & 108.6 & 109.8 & 109.2 & $0.73 \%$ & 7.39 & 7.45 & 7.42 & $0.52 \%$ \\
\hline & 5 & 95.4 & 95.9 & 95.6 & $0.39 \%$ & 6.85 & 6.87 & 6.86 & $0.28 \%$ \\
\hline & 6 & 99.0 & 99.0 & 99.0 & $0.02 \%$ & 7.04 & 7.01 & 7.03 & $0.34 \%$ \\
\hline & 7 & 98.8 & 96.9 & 97.9 & $1.42 \%$ & 7.07 & 6.99 & 7.03 & $0.81 \%$ \\
\hline \multirow{3}{*}{ SMP-ECR } & 3 & 103.6 & 105.1 & 104.3 & $1.05 \%$ & 7.11 & 7.31 & 7.21 & $1.96 \%$ \\
\hline & 6 & 83.6 & 83.0 & 83.3 & $0.55 \%$ & 6.41 & 6.38 & 6.39 & $0.32 \%$ \\
\hline & 7 & 96.1 & 97.3 & 96.7 & $0.87 \%$ & 6.96 & 7.00 & 6.98 & $0.38 \%$ \\
\hline
\end{tabular}

Table 1-14: Kaolin/Sand Bingham Plastic Rheological Data for September 2004 Test

\begin{tabular}{|c|c|c|c|c|c|c|c|c|c||}
\hline \multirow{2}{*}{$\begin{array}{c}\text { Sample } \\
\text { location }\end{array}$} & \multirow{2}{*}{$\begin{array}{c}\text { Day } \\
\text { Pulled }\end{array}$} & \multicolumn{3}{|c|}{ Yield Stress $\left(\right.$ dynes $\left./ \mathrm{cm}^{2}\right)$} & \multicolumn{4}{c|}{ Plastic Viscosity (cP) } \\
\cline { 3 - 10 } & Sample 1 & Sample 2 & Average & $\begin{array}{c}\text { \% standard } \\
\text { deviation }\end{array}$ & Sample 1 & Sample 2 & Average & $\begin{array}{c}\text { \% standard } \\
\text { deviation }\end{array}$ \\
\hline \multirow{3}{*}{ SMP-CWE } & 1 & 183.4 & 184.0 & 183.7 & $0.24 \%$ & 9.95 & 9.97 & 9.96 & $0.18 \%$ \\
\cline { 2 - 10 } & 4 & 133.8 & 135.6 & 134.7 & $0.94 \%$ & 8.23 & 8.16 & 8.19 & $0.61 \%$ \\
\cline { 2 - 10 } & 7 & 117.5 & 119.8 & 118.6 & $1.37 \%$ & 7.56 & 7.88 & 7.72 & $2.99 \%$ \\
\cline { 2 - 10 } & 10 & 104.7 & 104.4 & 104.5 & $0.19 \%$ & 7.16 & 7.10 & 7.13 & $0.62 \%$ \\
\hline \multirow{3}{*}{ SMP-ECR } & 1 & 183.3 & 179.9 & 181.6 & $1.31 \%$ & 9.87 & 9.54 & 9.71 & $2.41 \%$ \\
\cline { 2 - 10 } & 4 & 133.1 & 130.4 & 131.7 & $1.47 \%$ & 8.05 & 8.01 & 8.03 & $0.34 \%$ \\
\cline { 2 - 10 } & 118.6 & 115.2 & 116.9 & $2.06 \%$ & 7.65 & 7.44 & 7.55 & $2.01 \%$ \\
\cline { 2 - 10 } & 10 & 99.6 & 98.8 & 99.2 & $0.56 \%$ & 7.08 & 7.05 & 7.07 & $0.25 \%$ \\
\hline
\end{tabular}

The data in Table 1-13, Table 1-14 and Table 1-15 reveals that the samples pulled on the same day from the CWE are slightly more viscous when compared to the ECR samples. This is supported by the wt\% 
TS and density data, where the CWE results are greater than that of the ECR results, indicating that the rheology should be more viscous for the CWE samples.

Table 1-15: Kaolin/Sand Bingham Plastic Rheological Data for May 2005 Test

\begin{tabular}{|c|c|c|c|c|c|c|c|c|c|}
\hline \multirow{2}{*}{$\begin{array}{c}\text { Sample } \\
\text { location }\end{array}$} & \multirow{2}{*}{$\begin{array}{l}\text { Day } \\
\text { Pulled }\end{array}$} & \multicolumn{4}{|c|}{ Yield Stress (dynes/cm²) } & \multicolumn{4}{|c|}{ Plastic viscosity (cP) } \\
\hline & & Sample 1 & Sample 2 & Average & $\begin{array}{c}\text { \% standard } \\
\text { deviation }\end{array}$ & Sample 1 & Sample 2 & Average & $\begin{array}{c}\text { \% standard } \\
\text { deviation }\end{array}$ \\
\hline \multirow{7}{*}{ SMP-CWE } & 1 & 53.9 & 54.1 & 54.0 & $0.30 \%$ & 5.38 & 5.27 & 5.32 & $1.40 \%$ \\
\hline & 2 & 50.1 & 51.2 & 50.7 & $1.53 \%$ & 4.91 & 5.22 & 5.07 & $4.31 \%$ \\
\hline & 3 & 53.3 & 54.2 & 53.7 & $1.20 \%$ & 5.34 & 5.20 & 5.27 & $1.81 \%$ \\
\hline & 4 & 53.4 & 52.8 & 53.1 & $0.83 \%$ & 5.04 & 4.93 & 4.99 & $1.64 \%$ \\
\hline & 5 & 53.9 & 54.9 & 54.4 & $1.25 \%$ & 5.37 & 5.12 & 5.25 & $3.39 \%$ \\
\hline & 6 & 44.2 & 42.7 & 43.4 & $2.42 \%$ & 5.00 & 4.78 & 4.89 & $3.18 \%$ \\
\hline & 7 & 55.2 & 56.2 & 55.7 & $1.25 \%$ & 5.26 & 5.23 & 5.25 & $0.39 \%$ \\
\hline \multirow{7}{*}{ SMP-FFF } & 1 & 52.2 & 52.8 & 52.5 & $0.82 \%$ & 5.43 & 5.40 & 5.42 & $0.45 \%$ \\
\hline & 2 & 51.6 & 51.3 & 51.4 & $0.52 \%$ & 5.25 & 5.21 & 5.23 & $0.48 \%$ \\
\hline & 3 & 53.5 & 53.2 & 53.3 & $0.37 \%$ & 5.10 & 5.11 & 5.10 & $0.09 \%$ \\
\hline & 4 & 52.7 & 52.3 & 52.5 & $0.56 \%$ & 5.18 & 5.13 & 5.16 & $0.72 \%$ \\
\hline & 5 & 52.2 & 51.7 & 52.0 & $0.68 \%$ & 5.20 & 4.96 & 5.08 & $3.39 \%$ \\
\hline & 6 & 43.2 & 44.2 & 43.7 & $1.48 \%$ & 4.82 & 4.66 & 4.74 & $2.37 \%$ \\
\hline & 7 & 54.7 & 55.2 & 54.9 & $0.61 \%$ & 5.38 & 5.31 & 5.35 & $0.94 \%$ \\
\hline \multirow{7}{*}{ SMP-ECR } & 1 & 52.7 & 50.5 & 51.6 & $2.96 \%$ & 5.32 & 4.97 & 5.14 & $4.81 \%$ \\
\hline & 2 & 51.1 & 51.1 & 51.1 & $0.04 \%$ & 5.16 & 5.05 & 5.11 & $1.49 \%$ \\
\hline & 3 & 52.5 & 53.2 & 52.8 & $0.93 \%$ & 5.23 & 5.11 & 5.17 & $1.56 \%$ \\
\hline & 4 & 53.0 & 52.0 & 52.5 & $1.35 \%$ & 5.14 & 5.27 & 5.20 & $1.73 \%$ \\
\hline & 5 & 52.1 & 52.9 & 52.5 & $1.10 \%$ & 5.12 & 5.10 & 5.11 & $0.30 \%$ \\
\hline & 6 & 68.3 & 68.0 & 68.1 & $0.25 \%$ & 5.99 & 5.69 & 5.84 & $3.56 \%$ \\
\hline & 7 & 44.6 & 43.9 & 44.3 & $1.07 \%$ & 5.00 & 4.82 & 4.91 & $2.49 \%$ \\
\hline
\end{tabular}

\subsection{Particle Size Distribution}

\subsubsection{July 2004 Test Results}

Appendix C contains selected technical data of the B-100 dry kaolin used in the SMP tests. The $2^{\text {nd }}$ page of this appendix contains the particle size distribution (PSD), on an oxide mass basis, which indicates that 98 percent of the kaolin is smaller than 20 microns and 42 percent smaller than 0.5 microns. The results are summarized in Table 1-16. 
Table 1-16: Unimin B-100 Kaolin Particles Size Distribution

\begin{tabular}{|c|c|c|c||}
\hline \multirow{2}{*}{ Bin } & \multirow{2}{*}{ Size (microns) } & \multicolumn{2}{|c||}{ Percent Weight on Oxide Basis } \\
\cline { 3 - 4 } & & $\%$ in Bin & \% Cumulative \\
\hline 1 & $\geq 20$ & 2 & 100 \\
\hline 2 & $10 \leq \mathrm{x}<20$ & 6 & 98 \\
\hline 3 & $5 \leq \mathrm{x}<10$ & 9 & 92 \\
\hline 4 & $2 \leq \mathrm{x}<5$ & 16 & 83 \\
\hline 5 & $1 \leq \mathrm{x}<2$ & 11 & 67 \\
\hline 6 & $0.5 \leq \mathrm{x}<1$ & 14 & 56 \\
\hline 7 & $\mathrm{x}<0.5$ & 42 & 42 \\
\hline
\end{tabular}

The sand used during the SMP testing was an aggregate ${ }^{4}$ used for masonry mortar. The nominal particle size distribution provided in the ASTM specification, for either natural or manufactured sand is shown in Table 1-17.

Table 1-17: ASTM Specification for Aggregate (Sand) Used in SMP Test

\begin{tabular}{|c|c|c|c|}
\hline \multicolumn{2}{|c|}{ Sieve Size } & \multicolumn{2}{c|}{ Percent Passing } \\
\cline { 2 - 4 } & & Natural Sand & Manufactured Sand \\
\hline $4.75-\mathrm{mm}$ & No. 4 & 100 & 100 \\
\hline $2.36-\mathrm{mm}$ & No. 8 & 95 to 100 & 95 to 100 \\
\hline $1.18-\mathrm{mm}$ & No. 16 & 70 to 100 & 70 to 100 \\
\hline $600-\mu \mathrm{m}$ & No. 30 & 40 to 75 & 40 to 75 \\
\hline $300-\mu \mathrm{m}$ & No. 50 & 10 to 35 & 20 to 40 \\
\hline $150-\mu \mathrm{m}$ & No. 100 & 2 to 15 & 10 to 25 \\
\hline $75-\mu \mathrm{m}$ & No. 200 & 0 to 5 & 0 to 10 \\
\hline
\end{tabular}

A sample of the sand that was provided to SRNL was dried and the PSD was determined using an ATM Sonic Sifter, which utilizes ASTM sieves. The sonic sifter uses both vibration and pulsing to sieve the material through the selected ASTM sieves. The sieves used and results are provided in Table 1-18. Table 1-17 and Table 1-18 clearly show that the sand particles are much larger than that of the B-100 kaolin.

Table 1-18: Particle Size Distribution of Aggregate (Sand) for July 2004 Test

\begin{tabular}{|c|c|c|c|c|c|c|}
\hline \multicolumn{2}{|c|}{ Sieves } & \multicolumn{4}{|c|}{ Sample } & \multirow{2}{*}{ Average } \\
\hline Sieve Size & Micron & $\# 1$ & \#2 & \#3 & $\# 4$ & \\
\hline $425 \mu \mathrm{m}$ & $x \geq 425$ & $39.13 \%$ & $33.31 \%$ & $40.90 \%$ & $31.16 \%$ & $36.13 \%$ \\
\hline $250 \mu \mathrm{m}$ & $425>x \geq 250$ & $40.00 \%$ & $39.54 \%$ & $39.84 \%$ & $38.91 \%$ & $39.57 \%$ \\
\hline $180 \mu \mathrm{m}$ & $250>x \geq 180$ & $12.69 \%$ & $16.31 \%$ & $12.36 \%$ & $15.64 \%$ & $14.25 \%$ \\
\hline $125 \mu \mathrm{m}$ & $180>x \geq 125$ & $6.24 \%$ & $7.65 \%$ & $5.50 \%$ & $9.81 \%$ & $7.30 \%$ \\
\hline $75 \mu \mathrm{m}$ & $125>x \geq 75$ & $1.61 \%$ & $2.63 \%$ & $1.25 \%$ & $3.65 \%$ & $2.28 \%$ \\
\hline $45 \mu \mathrm{m}$ & $75>x \geq 45$ & $0.20 \%$ & $0.41 \%$ & $0.11 \%$ & $0.62 \%$ & $0.33 \%$ \\
\hline Fines Collector & $x<45$ & $0.13 \%$ & $0.14 \%$ & $0.04 \%$ & $0.22 \%$ & $0.13 \%$ \\
\hline
\end{tabular}

\footnotetext{
${ }^{4}$ ASTM C144-03, “Standard Specification For Aggregate for Masonry Mortar”, 2003
} 
A Microtrac S-3000 particle size analyzer was used to measure the PSD of the kaolin/sand samples. Prior to analyzing the sample, the kaolin/sand samples were diluted using DI water. The S-3000 particle size analyzer measures the particle diameters by measuring the scattered light from a laser beam projected through a stream of the fluid carrying the diluted sample. The amount and direction of the light scattered by the particles is measured by an optical detector array and then analyzed to determine the size distribution of the particles. The S-3000 measuring range is between 0.026 to $1408 \mu \mathrm{m}$ and was checked using NIST traceable particle size standards. The sample is run three times and the values averaged. The particle size distribution, both volume (would be mass basis if only one type of material is being tested or if the different materials all have the same density) and number are provide in Appendix B for the requested data in Table 1-2. The mean volume and number diameters are provided in Table 1-19. The mean number diameters are fairly constant, stating that there are a lot of small particles, most likely from the kaolin. There are slight variations between the mean volume diameter and this is due to a large particle being measured (large particles can easily shift this distribution). It is hard to determine based on this assessment if the sand used in the slurry degraded to a smaller particle sizes due to pumping or if the larger sand particles settled out of the slurry. Scraping of the tank bottom using a pole and pulling inspection samples in the ECR area near the bottom of the tank showed that sand had settled and was not being resuspended by the flow field. There were no specifications for particle size in either the TAR or the SMP procurement specification.

Table 1-19: Mean Volume and Mean Number Particle Size Using Micotrac S3000 for July 2004 Test

\begin{tabular}{|c|c|c|c|}
\hline Sample location & $\begin{array}{c}\text { Day } \\
\text { Pulled }\end{array}$ & $\begin{array}{c}\text { Mean volume } \\
(\mu \mathrm{m})\end{array}$ & $\begin{array}{c}\text { Mean Number } \\
(\mu \mathrm{m})\end{array}$ \\
\hline \multirow{2}{*}{ SMP-CWE } & 4 & 6.709 & 0.651 \\
\cline { 2 - 4 } & 7 & 9.475 & 0.626 \\
\hline \multirow{2}{*}{ SMP-FFF } & 4 & 6.799 & 0.639 \\
\cline { 2 - 4 } & 7 & 12.50 & 0.622 \\
\hline \multirow{3}{*}{ SMP-ECR } & 3 & 5.876 & 0.625 \\
\cline { 2 - 4 } & 6 & 14.02 & 0.622 \\
\cline { 2 - 4 } & 7 & 6.374 & 0.654 \\
\hline
\end{tabular}

\subsubsection{September 2004 Test Results}

During the September 2004 SMP run, a second $400 \mathrm{~mL}$ sample bottle was pulled at various locations and times to determine if the contribution of the sand and the particle size distribution of the sand in the kaolin/sand slurries could be determined. Baseline conditions, such as the PSD of the sand and Kaolin were first individually determined.

A sample of the sand used during the September 2004 test was provided to SRNL. A portion of the sand was washed and dried. The ATM Sonic Sifter (see Figure 1-4) and six ASTM sieves (based on the ASTM information provided in Table 1-17) were used. The sonic sifter was set for 5 minutes of continuous vibration and maximum pulsation. Four sand samples (40 to 51 grams each) were analyzed using the ATM Sonic Sifter and the results are shown in Table 1-20. The results indicate the analyzed sand has a smaller particle than that stated in Table 1-17. For instance, in Table 1-17, a maximum of 75\% of the particles passed through the 600 micron mesh. In Table 1-20, about $85 \%$ of the particles passed through the 600 micron mesh. Below 300 microns, the data compares well. The difference at the larger 
micron sizes could be due to how the sample(s) were obtained and prepared. The data reflects that $99.7 \%$ of the particles are larger than 75 micron in diameter.

Dry unprocessed B-100 kaolin was used to measure particles in the B-100 kaolin which were greater that $45 \mu \mathrm{m}$ in diameter, using the same ASTM sieves as that of the sand. Three dry B-100 samples were randomly sampled, made as a slurry using water, and washed through a $45 \mu \mathrm{m}$ ASTM sieve using water. The solids captured in the $45 \mu \mathrm{m}$ sieve were placed onto a filter and dried. These particles were then sieved using the ATM Sonic Sifter. The results are shown in Table 1-21. The percent mass of particles greater than $45 \mu \mathrm{m}$ was $0.56 \%$, with $86.5 \%$ of these particles between $45 \mu \mathrm{m}$ to $125 \mu \mathrm{m}$. The B-100 kaolin is definitely much small in size than the sand.

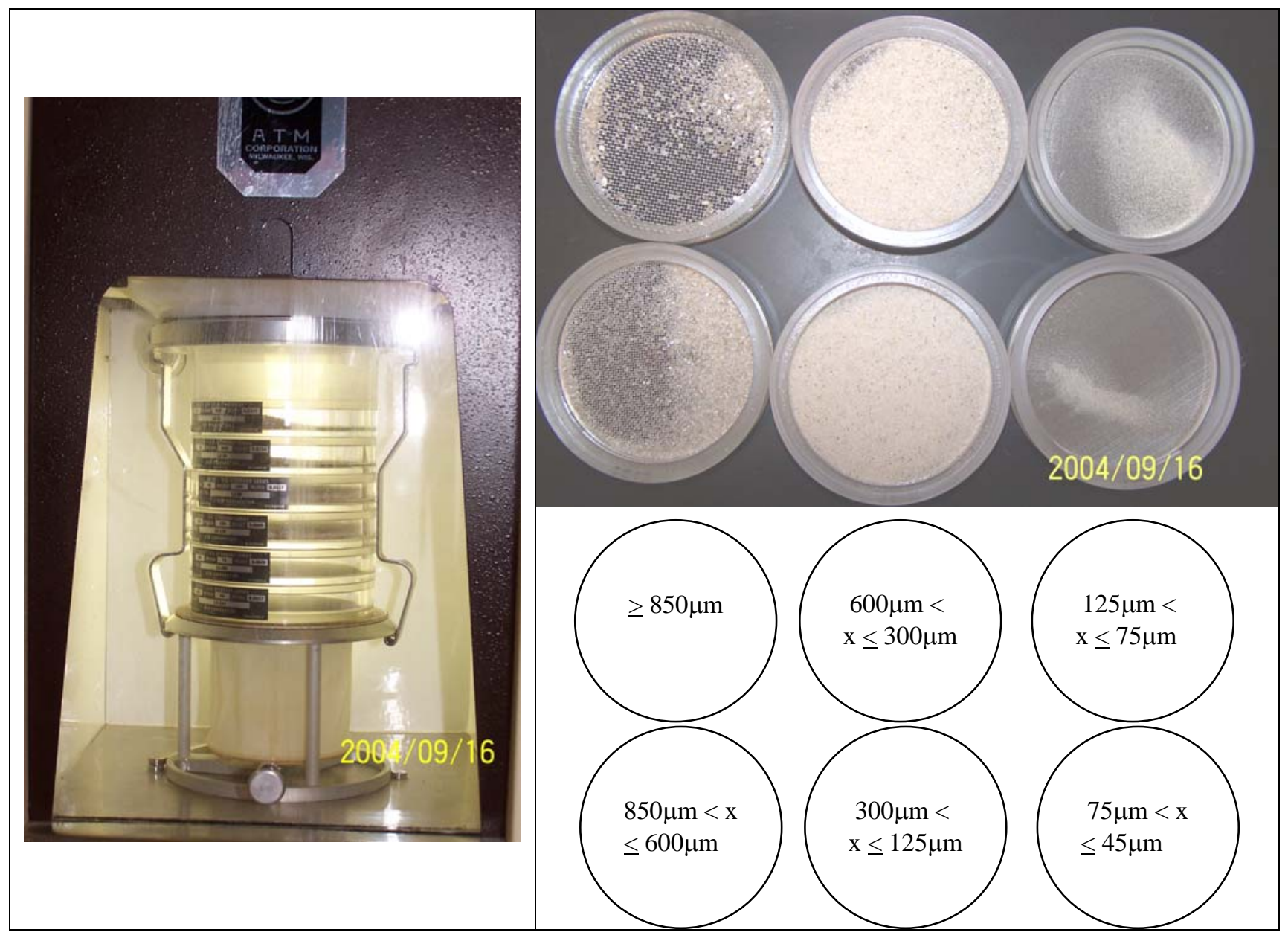

Figure 1-4: ATM Sonic Sifter and Typical PSD of Sand Sample from September 2004 SMP Test 
Table 1-20: Particle Size Distribution of Sand Used During September 2004 Test

\begin{tabular}{|c|c|c|c|c|c|}
\hline \hline microns & $\begin{array}{c}\text { Sample \#1 } \\
(49.831 \mathrm{~g})\end{array}$ & $\begin{array}{c}\text { Sample \#2 } \\
(44.006 \mathrm{~g})\end{array}$ & $\begin{array}{c}\text { Sample \#3 } \\
(40.403 \mathrm{~g})\end{array}$ & $\begin{array}{c}\text { Sample \#4 } \\
(51.676 \mathrm{~g})\end{array}$ & Average \\
\hline $\mathrm{x} \geq 850$ & $5.09 \%$ & $6.20 \%$ & $5.61 \%$ & $5.02 \%$ & $5.48 \%$ \\
\hline $850>\mathrm{x} \geq 600$ & $10.55 \%$ & $11.49 \%$ & $10.60 \%$ & $10.17 \%$ & $10.70 \%$ \\
\hline $600>\mathrm{x} \geq 300$ & $47.43 \%$ & $48.26 \%$ & $48.02 \%$ & $47.50 \%$ & $47.80 \%$ \\
\hline $300>\mathrm{x} \geq 125$ & $34.82 \%$ & $32.14 \%$ & $33.70 \%$ & $34.95 \%$ & $33.90 \%$ \\
\hline $125>\mathrm{x} \geq 75$ & $1.93 \%$ & $1.71 \%$ & $1.87 \%$ & $2.11 \%$ & $1.91 \%$ \\
\hline $75>\mathrm{x} \geq 45$ & $0.17 \%$ & $0.18 \%$ & $0.18 \%$ & $0.22 \%$ & $0.19 \%$ \\
\hline $\mathrm{x}<45$ & $0.01 \%$ & $0.03 \%$ & $0.02 \%$ & $0.02 \%$ & $0.02 \%$ \\
\hline
\end{tabular}

Table 1-21: Percent Mass Contribution and PSD of B-100 Kaolin Greater Than 45 Microns

\begin{tabular}{||c|c|c|c|c||}
\hline \hline Description & Sample \# 1 & Sample \# 2 & Sample \# 3 & Average \\
\hline Total Mass (grams) & 49.25 & 63.303 & 60.383 & N/A \\
\hline mass $>45 \mu \mathrm{m}$ (grams) & 0.292 & 0.356 & 0.317 & N/A \\
\hline$\%$ mass $>45 \mu \mathrm{m}$ & $0.59 \%$ & $0.56 \%$ & $0.52 \%$ & $0.56 \%$ \\
\hline \hline Microns & \multicolumn{5}{|c|}{ Distribution of particles greater than 45 microns } \\
\hline $75>\mathrm{x} \geq 45$ & $60.62 \%$ & $60.39 \%$ & $51.42 \%$ & $57.48 \%$ \\
\hline $125>\mathrm{x} \geq 75$ & $23.63 \%$ & $28.09 \%$ & $35.33 \%$ & $29.02 \%$ \\
\hline $300>\mathrm{x} \geq 125$ & $10.27 \%$ & $7.02 \%$ & $8.83 \%$ & $8.71 \%$ \\
\hline $600>\mathrm{x} \geq 300$ & $3.77 \%$ & $1.97 \%$ & $2.21 \%$ & $2.65 \%$ \\
\hline $850>\mathrm{x} \geq 600$ & $1.71 \%$ & $1.69 \%$ & $1.58 \%$ & $1.66 \%$ \\
\hline $\mathrm{x} \geq 850$ & $0.00 \%$ & $0.84 \%$ & $0.63 \%$ & $0.49 \%$ \\
\hline \hline
\end{tabular}

The kaolin/sand slurry samples designated for sand contribution analyses were processed through a 45 $\mu \mathrm{m}$ sieve by washing the kaolin/sand slurry using water. The solids captured in the $45 \mu \mathrm{m}$ ASTM sieve were placed onto a filter and dried. These particles were then sieved using the ATM Sonic Sifter to determine the particle size distribution (using the same sieves as that of the sand and kaolin) and the mass greater than $45 \mu \mathrm{m}$. The mass of the kaolin/sand slurry sample, the wt\% total solids in the slurry sample, mass of particles greater than $45 \mu \mathrm{m}$, and the wt\% of kaolin greater than $45 \mu \mathrm{m}$ were used to calculate other parameter and the method used is shown in Appendix D. The calculated parameters were the mass of total solids in the slurry, mass of kaolin greater that $45 \mu \mathrm{m}$, mass of sand, and wt\% mass of sand in the total solids. These parameters, as well as the distribution of the dry particles greater than $45 \mu \mathrm{m}$ are provided in Table 1-22. The data from day 4 to day 7 shows that the mass of material greater than $45 \mu \mathrm{m}$ was decreasing and is expected if the sand continuously settles out of the slurry. The SMP-CWE and SMP-FF samples on the $10^{\text {th }}$ day increased drastically, indicating something had changed during the test, which caused the contribution of sand to increase.

There was no attempt to subtract the kaolin particles (using the analysis from Table 1-21) from the particle size distribution provided in Table 1-22. If corrected, the contribution from the smaller particles would have decreased. Another contributor in reducing the size of the sand its original particle size distribution, though slight, is the direct impact (degradation) of the sand with the pump impeller/casing during pumping operations. 
Table 1-22: Sand Contribution Analyzes From the September 2004 Test

\begin{tabular}{|c|c|c|c|c|c|c|c|c|c|}
\hline Description & \multicolumn{3}{|c|}{ SMP-CWE } & \multicolumn{3}{|c|}{ SMP-FFF } & \multicolumn{3}{|c|}{ SMP-ECR } \\
\hline Day & 4 & 7 & 10 & 4 & 7 & 10 & 4 & 7 & 10 \\
\hline $\mathrm{Wt} \% \mathrm{TS}$ & 25.57 & 23.79 & 22.81 & 24.63 & 23.55 & 22.13 & 27.33 & 24.67 & 23.67 \\
\hline$\%$ mass of sand in the slurry & 0.51 & 0.37 & 1.65 & 0.27 & 0.06 & 0.63 & 0.21 & 0.59 & 0.10 \\
\hline$\%$ mass of sand in total solids & 2.01 & 1.54 & 7.25 & 1.08 & 0.26 & 2.85 & 0.77 & 2.38 & 0.41 \\
\hline $\begin{array}{c}\% \text { particles }>45 \mu \mathrm{m} \text { in total } \\
\text { solids }\end{array}$ & 2.56 & 2.09 & 7.77 & 1.63 & 0.82 & 3.40 & 1.33 & 2.93 & 0.97 \\
\hline$\%$ kaolin for particles $>45 \mu \mathrm{m}$ & 21.48 & 26.36 & 6.68 & 33.95 & 68.52 & 16.01 & 41.92 & 18.67 & 57.75 \\
\hline Microns & \multicolumn{9}{|c|}{ Distribution of particles greater than 45 microns in the kaolin/sand slurry sample } \\
\hline $75>x \geq 45$ & $15.55 \%$ & $23.66 \%$ & $3.49 \%$ & $26.60 \%$ & $18.74 \%$ & $9.85 \%$ & $16.26 \%$ & $12.79 \%$ & $29.47 \%$ \\
\hline $125>x \geq 75$ & $12.30 \%$ & $21.92 \%$ & $5.00 \%$ & $17.65 \%$ & $31.46 \%$ & $10.39 \%$ & $19.99 \%$ & $11.27 \%$ & $29.00 \%$ \\
\hline $300>x \geq 125$ & $54.96 \%$ & $48.74 \%$ & $45.91 \%$ & $43.81 \%$ & $41.97 \%$ & $47.23 \%$ & $50.09 \%$ & $44.27 \%$ & $36.58 \%$ \\
\hline $600>x \geq 300$ & $15.65 \%$ & $4.68 \%$ & $41.41 \%$ & $10.32 \%$ & $4.40 \%$ & $29.01 \%$ & $12.33 \%$ & $28.79 \%$ & $3.17 \%$ \\
\hline $850>x \geq 600$ & $1.03 \%$ & $0.73 \%$ & $3.70 \%$ & $1.33 \%$ & $2.44 \%$ & $2.77 \%$ & $1.20 \%$ & $2.44 \%$ & $1.01 \%$ \\
\hline$X \geq 850$ & $0.51 \%$ & $0.28 \%$ & $0.50 \%$ & $0.28 \%$ & $0.98 \%$ & $0.75 \%$ & $0.13 \%$ & $0.45 \%$ & $0.77 \%$ \\
\hline
\end{tabular}

Table 1-23: Mean Volume and Mean Number Particle Size Using Microtrac S3000 for September 2004 Test

\begin{tabular}{|c|c|c|c|c|}
\hline Sample location & $\begin{array}{c}\text { Day } \\
\text { Pulled }\end{array}$ & $\begin{array}{c}\text { Mean volume } \\
(\mu \mathrm{m})\end{array}$ & $\begin{array}{c}\text { Volume \% greater } \\
\text { than } 44 \mu \mathrm{m}(\%)\end{array}$ & $\begin{array}{c}\text { Mean Number } \\
(\mu \mathrm{m})\end{array}$ \\
\hline \multirow{4}{*}{ SMP-CWE } & 1 & 7.191 & 1.00 & 0.652 \\
\cline { 2 - 5 } & 4 & 7.865 & 2.39 & 0.640 \\
\cline { 2 - 5 } & 7 & 6.668 & 0.42 & 0.650 \\
\cline { 2 - 5 } & 10 & 15.15 & 0.75 & 0.620 \\
\hline \multirow{5}{*}{ SMP-FFF } & 1 & 7.253 & 1.16 & 0.650 \\
\cline { 2 - 6 } & 4 & 7.483 & 1.67 & 0.642 \\
\cline { 2 - 6 } & 7 & 7.064 & 1.07 & 0.649 \\
\cline { 2 - 6 } & 10 & 6.822 & 9.00 & 0.651 \\
\hline \multirow{5}{*}{ SMP-ECR } & 1 & 7.595 & 1.90 & 0.640 \\
\cline { 2 - 5 } & 4 & 7.696 & 2.09 & 0.642 \\
\cline { 2 - 5 } & 7 & 9.643 & 4.24 & 0.627 \\
\cline { 2 - 6 } & 10 & 11.87 & 5.97 & \\
\hline
\end{tabular}

Samples of the kaolin/sand slurries were also analyzed using the Microtrac S3000 (see section 1.4.1 for description) and the mean volume and number diameters are provided in Table 1-23. The mean number diameters are fairly constant, stating that there are a lot of small particles, which are from the Kaolin. There are slight variations between the mean volume diameter and this is due to a large particle being measured (large particles can easily shift this distribution, since volume is a cubic function with respect to diameter). There were no specifications for particle size in either the TAR or the SMP procurement specification. The volume and number distributions are provided in appendix B. Table 1-23 also lists the volume $\%$ greater than $44 \mu \mathrm{m}$. The volume $\%$ is very close to the \% mass distribution, given that the density of Kaolin $(\approx 2.6 \mathrm{~g} / \mathrm{mL})$ and sand $(\approx 2.5 \mathrm{~g} / \mathrm{mL})$ are very similar. This data does not compare well with the greater than $45 \mu \mathrm{m}$ sand data in Table 1-22. The Microtrac data is not that useful for determining the contribution of sand, which could be due to how a kaolin/sand sample is processed. Approximately 5 
$\mathrm{mL}$ of a kaolin/sand slurry sample is diluted with $500 \mathrm{~mL}$ of de-ionized water and this resulting slurry is then used with the S3000 for analysis.

\subsubsection{May 2005 Test Results}

A sample of sand used in the May 2005 test was analyzed and the results are shown in Table 1-24. This PSD distribution is very similar to the PSD of the sand analyzed in the September 2004 test (see Table 1-20).

Table 1-24: Particle Size Distribution of Sand for May 2005 Test

\begin{tabular}{|c|c|c|c|c|c|c||}
\hline \multicolumn{2}{|c|}{ Sieves } & \multicolumn{4}{c|}{ Sample } & \multirow{2}{*}{ Average } \\
\cline { 1 - 5 } Sieve Size & Micron & $\# 1$ & $\# 2$ & $\# 3$ & $\# 4$ & \\
\hline $425 \mu \mathrm{m}$ & $\mathrm{x} \geq 425$ & $34.52 \%$ & $39.59 \%$ & $33.72 \%$ & $31.26 \%$ & $34.77 \%$ \\
\hline $250 \mu \mathrm{m}$ & $425>\mathrm{x} \geq 250$ & $38.68 \%$ & $38.16 \%$ & $39.63 \%$ & $37.14 \%$ & $38.40 \%$ \\
\hline $180 \mu \mathrm{m}$ & $250>\mathrm{x} \geq 180$ & $16.04 \%$ & $13.59 \%$ & $16.82 \%$ & $18.09 \%$ & $16.13 \%$ \\
\hline $125 \mu \mathrm{m}$ & $180>\mathrm{x} \geq 125$ & $7.79 \%$ & $6.18 \%$ & $7.28 \%$ & $9.72 \%$ & $7.74 \%$ \\
\hline $75 \mu \mathrm{m}$ & $125>\mathrm{x} \geq 75$ & $2.17 \%$ & $1.95 \%$ & $2.28 \%$ & $2.99 \%$ & $2.35 \%$ \\
\hline $45 \mu \mathrm{m}$ & $75>\mathrm{x} \geq 45$ & $0.56 \%$ & $0.43 \%$ & $0.16 \%$ & $0.72 \%$ & $0.47 \%$ \\
\hline Fines Collector & $\mathrm{x}<45$ & $0.25 \%$ & $0.11 \%$ & $0.11 \%$ & $0.08 \%$ & $0.14 \%$ \\
\hline
\end{tabular}

The May 2005 sand contribution samples were processed in the same manner as that of the September 2004 SMP test samples (see section 1.4.2). The results are presented in Table 1-25. Unlike the other tests, the concentration of kaolin/sand was targeted at $20 \mathrm{wt} \%$, where the solids contribution from Kaolin was $90 \%$ by mass and the other $10 \%$ was from the sand. The data in this table clearly shows that the as the test progressed, the quantity of sand in suspension decreased and ultimately settled on the bottom of the test vessel.

Table 1-25: Sand Contribution Analyzes for May 2005 Test

\begin{tabular}{|c|c|c|c|c|c|c|c|c|c||}
\hline Description & \multicolumn{3}{|c|}{ SMP-CWE } & \multicolumn{3}{c|}{ SMP-FFF } & \multicolumn{3}{c|}{ SMP-ECR } \\
\hline Day & 1 & 2 & 7 & 1 & 2 & 7 & 1 & 2 & 7 \\
\hline Wt\% Total Solids & 19.87 & 18.39 & 18.24 & 18.67 & 17.99 & 18.12 & 18.65 & 18.00 & 16.98 \\
\hline \% mass of sand in slurry & 1.95 & 0.63 & 0.10 & 0.61 & 0.23 & 0.08 & 0.62 & 0.23 & 0.09 \\
\hline \% mass of sand in total solids & 9.80 & 3.37 & 0.57 & 3.28 & 1.27 & 0.44 & 3.31 & 1.24 & 0.51 \\
\hline $\begin{array}{c}\text { \% particles }>45 \mu \mathrm{m} \text { in total } \\
\text { solids }\end{array}$ & 10.30 & 3.91 & 1.13 & 3.82 & 1.82 & 0.99 & 3.85 & 1.80 & 1.07 \\
\hline \% kaolin for particles $>45 \mu \mathrm{m}$ & 4.90 & 13.84 & 49.25 & 14.18 & 30.33 & 56.13 & 14.06 & 30.81 & 52.25 \\
\hline \hline Microns & \multicolumn{1}{|c|}{ Distribution of particles greater than 45 microns in the kaolin/sand slurry sample } \\
\hline $75>\mathrm{x} \geq 45$ & $4.97 \%$ & $14.68 \%$ & $40.16 \%$ & $13.95 \%$ & $23.01 \%$ & $43.80 \%$ & $14.87 \%$ & $20.08 \%$ & $45.16 \%$ \\
\hline $125>\mathrm{x} \geq 75$ & $3.60 \%$ & $9.74 \%$ & $19.78 \%$ & $4.76 \%$ & $15.18 \%$ & $22.60 \%$ & $4.79 \%$ & $14.56 \%$ & $21.85 \%$ \\
\hline $300>\mathrm{x} \geq 125$ & $41.61 \%$ & $50.82 \%$ & $30.59 \%$ & $32.74 \%$ & $41.08 \%$ & $26.68 \%$ & $32.71 \%$ & $43.51 \%$ & $25.76 \%$ \\
\hline $600>\mathrm{x} \geq 300$ & $43.67 \%$ & $23.89 \%$ & $8.47 \%$ & $40.46 \%$ & $18.62 \%$ & $6.06 \%$ & $39.83 \%$ & $19.59 \%$ & $6.09 \%$ \\
\hline $850>\mathrm{x} \geq 600$ & $4.63 \%$ & $0.80 \%$ & $0.72 \%$ & $6.30 \%$ & $1.67 \%$ & $0.59 \%$ & $5.96 \%$ & $1.95 \%$ & $0.78 \%$ \\
\hline $\mathrm{x} \geq 850$ & $1.53 \%$ & $0.07 \%$ & $0.29 \%$ & $1.79 \%$ & $0.44 \%$ & $0.27 \%$ & $1.83 \%$ & $0.32 \%$ & $0.36 \%$ \\
\hline
\end{tabular}


Samples of the kaolin/sand slurries were also analyzed using the Microtrac S3000 (see section 1.4.1 for description) and the mean volume and number diameters are provided in Table 1-26. This data is very similar to the Microtrac S3000 data for the September 2004 test as described above. As with the September 2004 data, this data is not that useful in determining the mass of particles greater than $45 \mu \mathrm{m}$.

Table 1-26: Mean Volume and Mean Number Particle Size Using Microtrac S3000 For May 2005 Test

\begin{tabular}{|c|c|c|c|c|}
\hline \multirow{2}{*}{ Sample location } & $\begin{array}{c}\text { Day } \\
\text { Pulled }\end{array}$ & $\begin{array}{c}\text { Mean volume } \\
(\mu \mathrm{m})\end{array}$ & $\begin{array}{c}\text { Volume \% greater } \\
\text { than } 44 \mu \mathrm{m}(\%)\end{array}$ & $\begin{array}{c}\text { Mean Number } \\
(\mu \mathrm{m})\end{array}$ \\
\hline \multirow{2}{*}{ SMP-CWE } & 1 & 10.49 & 4.49 & 0.613 \\
\cline { 2 - 5 } & 7 & 10.78 & 5.77 & 0.624 \\
\hline \multirow{2}{*}{ SMP-FFF } & 1 & 7.220 & 0.33 & 0.642 \\
\cline { 2 - 5 } & 7 & 6.533 & 0.58 & 0.652 \\
\hline \multirow{2}{*}{ SMP-ECR } & 1 & 6.409 & 1.56 & 0.649 \\
\cline { 2 - 5 } & 7 & 6.746 & 1.00 & 0.648 \\
\hline
\end{tabular}

\subsection{REFERENCE}

WSRC-NB-2004-00122, Laboratory Notebook, “TNX Physical Properties of Kaolin” 
WSRC-TR-2004-00401

Revision 1

This page intentionally left blank. 
WSRC-TR-2004-00401

Revision 1

APPENDIX A. DOWN FLOW CURVES FITTED TO BINGHAM PLASTIC 

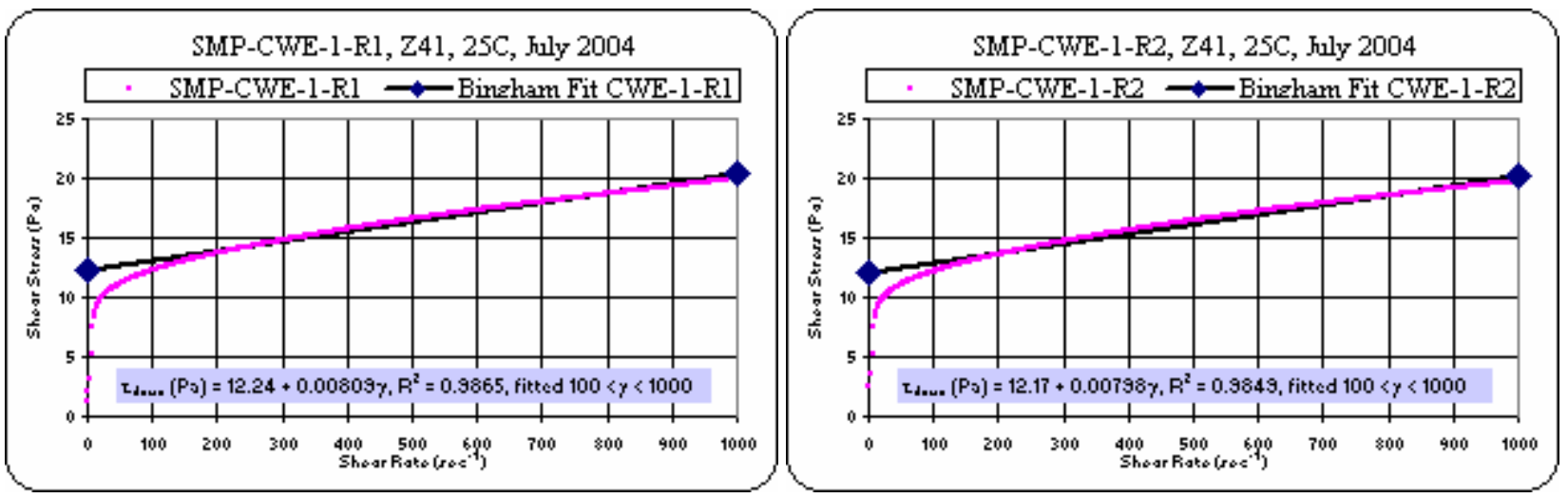

Figure A - 1: Down Flow Curve Sample SMP-CWE-1, July 2004
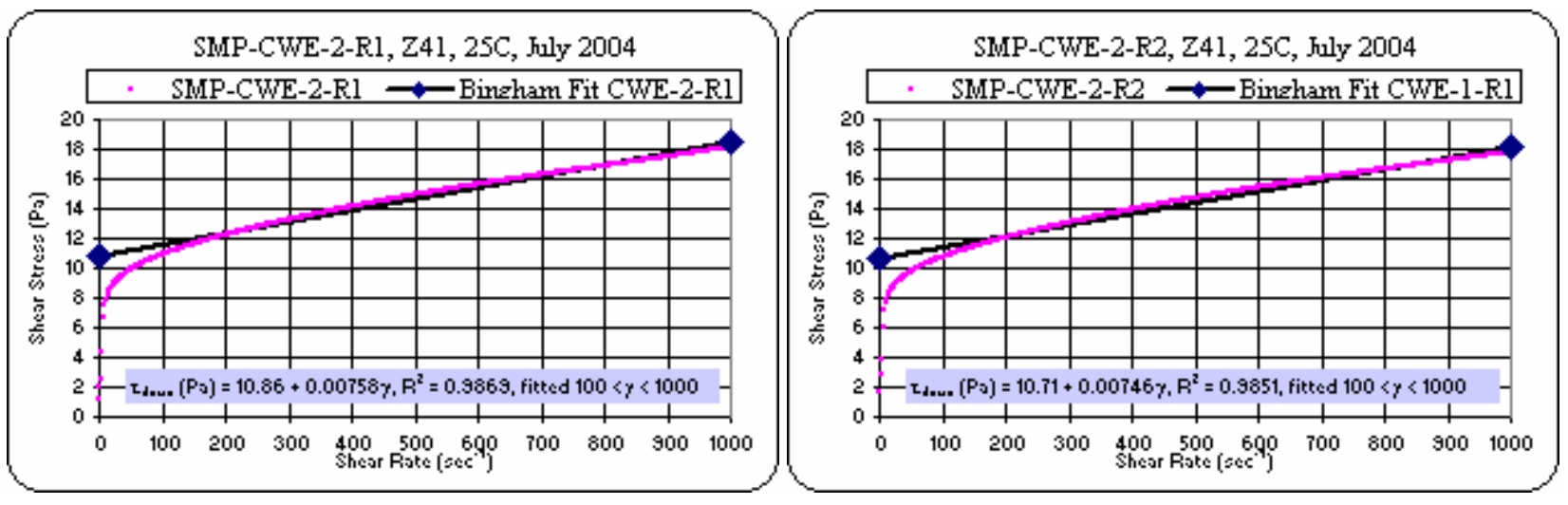

Figure A - 2: Down Flow Curve Sample SMP-CWE-2, July 2004
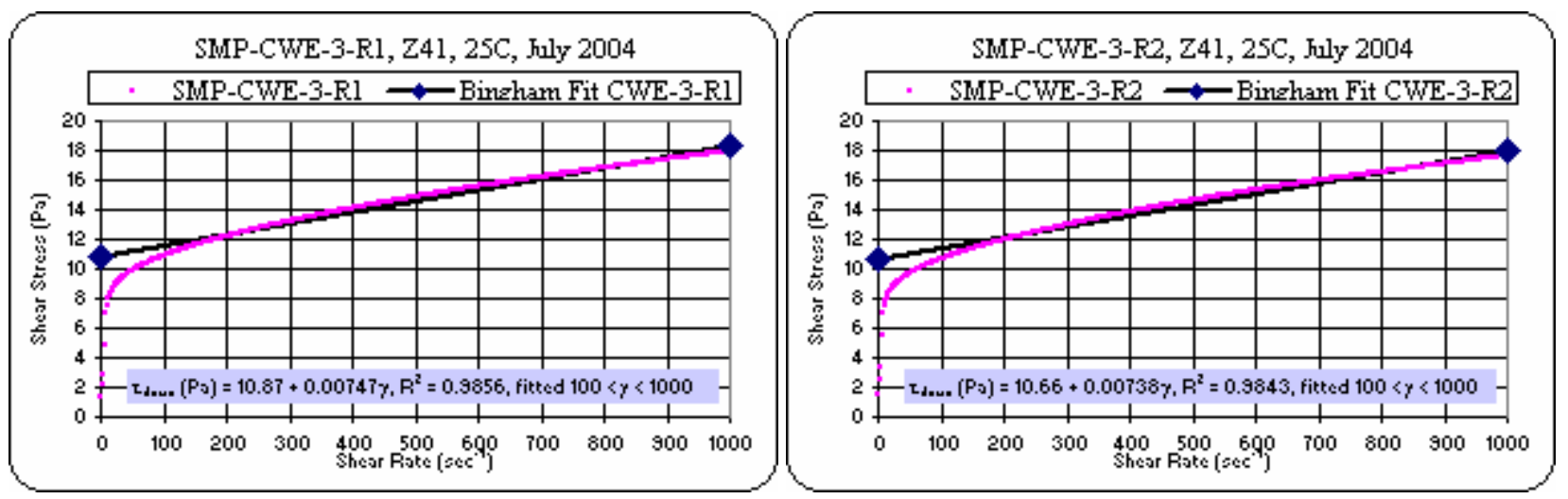

Figure A - 3: Down Flow Curve Sample SMP-CWE-3, July 2004 

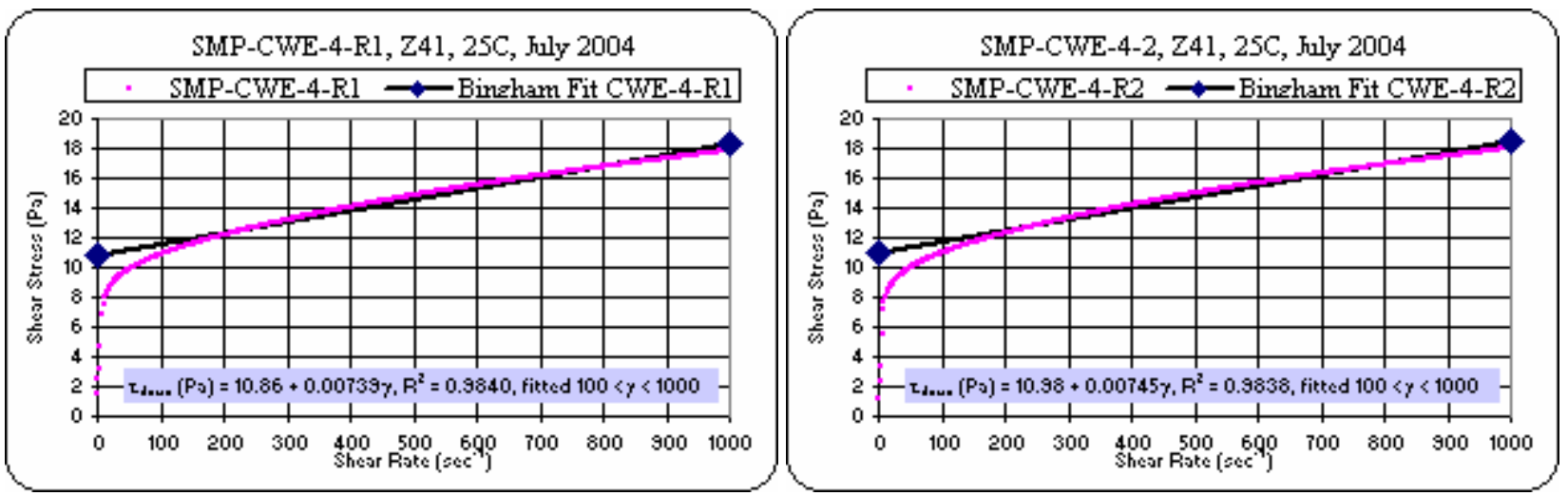

Figure A - 4: Down Flow Curve Sample SMP-CWE-4, July 2004
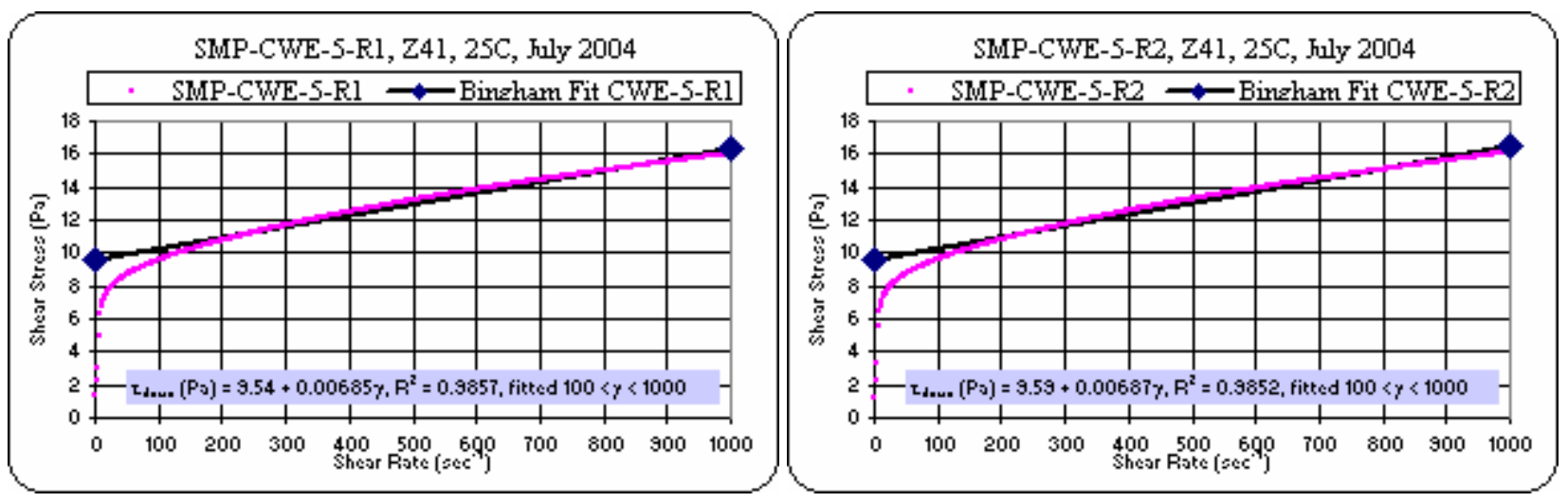

Figure A - 5: Down Flow Curve Sample SMP-CWE-5, July 2004
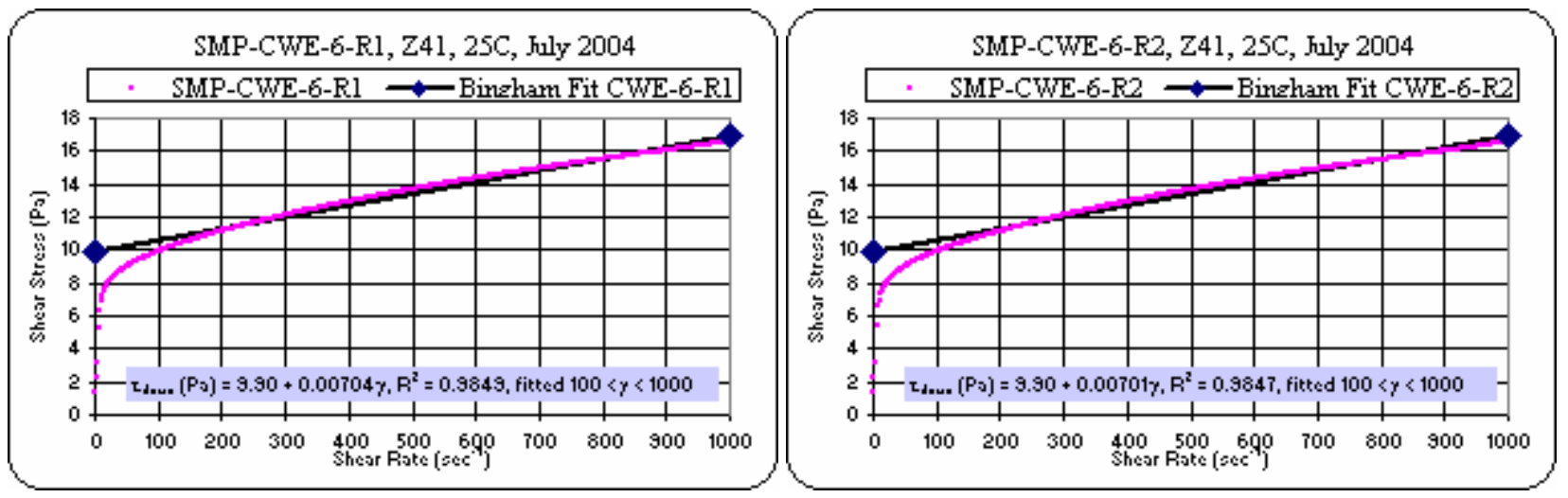

Figure A - 6: Down Flow Curve Sample SMP-CWE-6, July 2004 

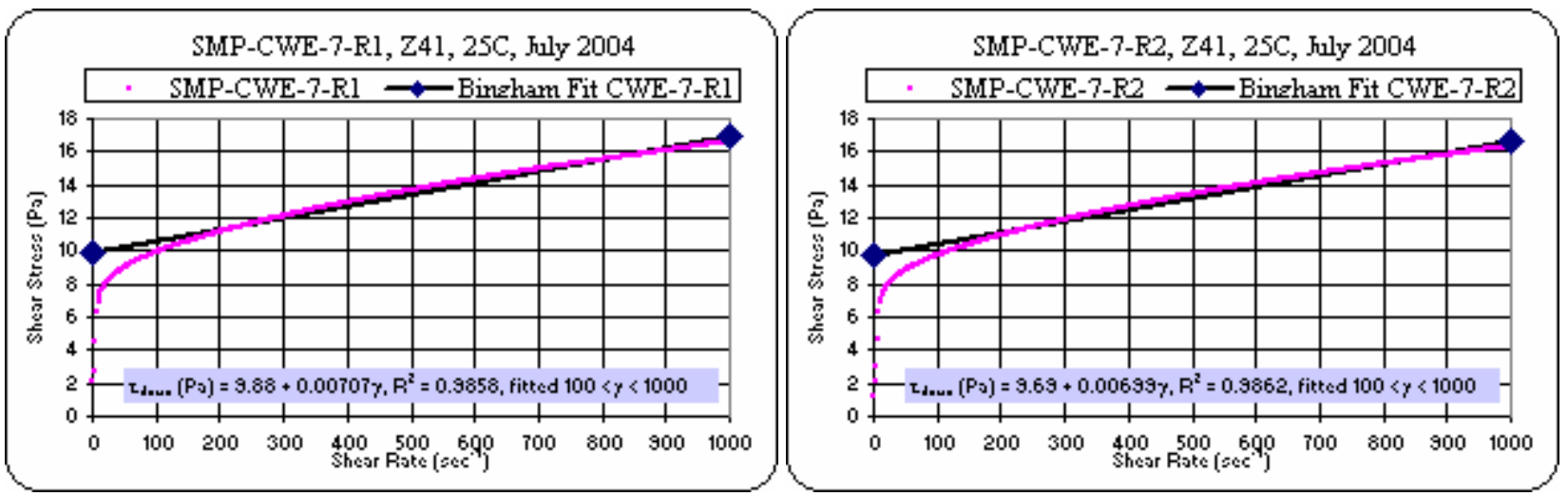

Figure A - 7: Down Flow Curve Sample SMP-CWE-7, July 2004
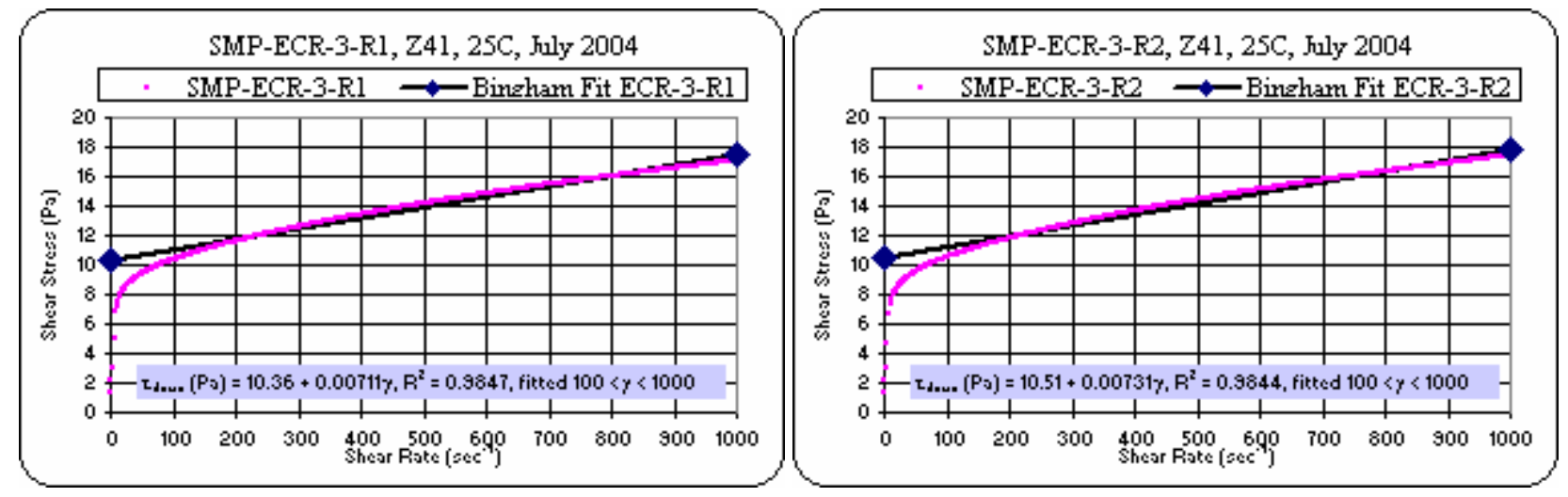

Figure A - 8: Down Flow Curve Sample SMP-ECR-3, July 2004
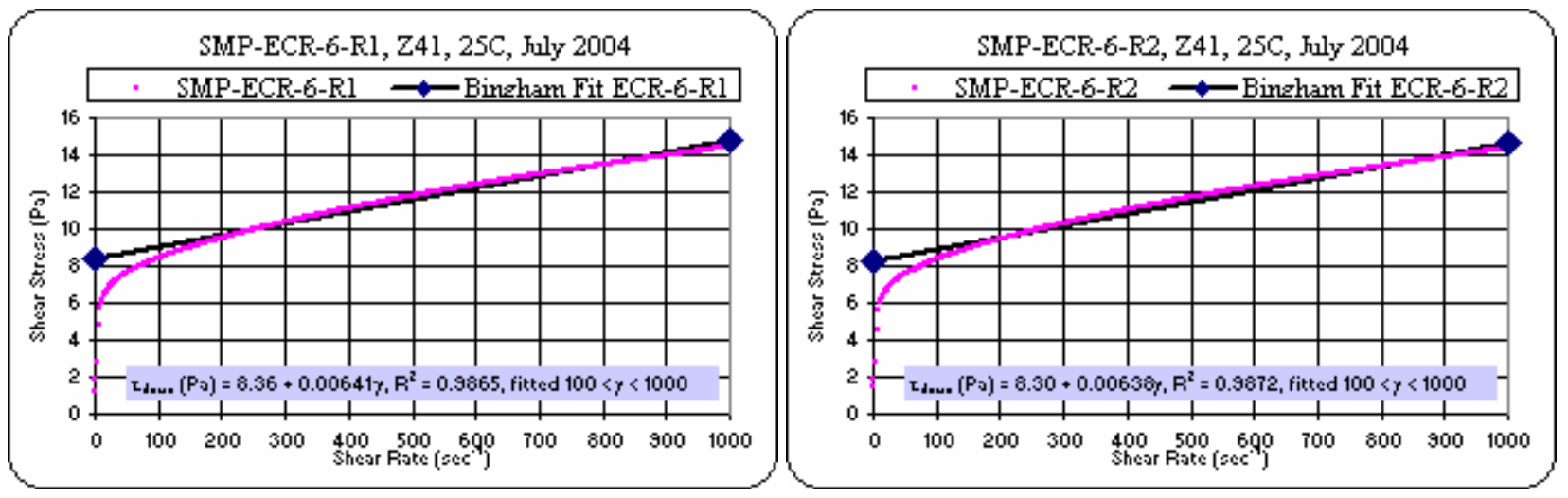

Figure A - 9: Down Flow Curve Sample SMP-ECR-6, July 2004 

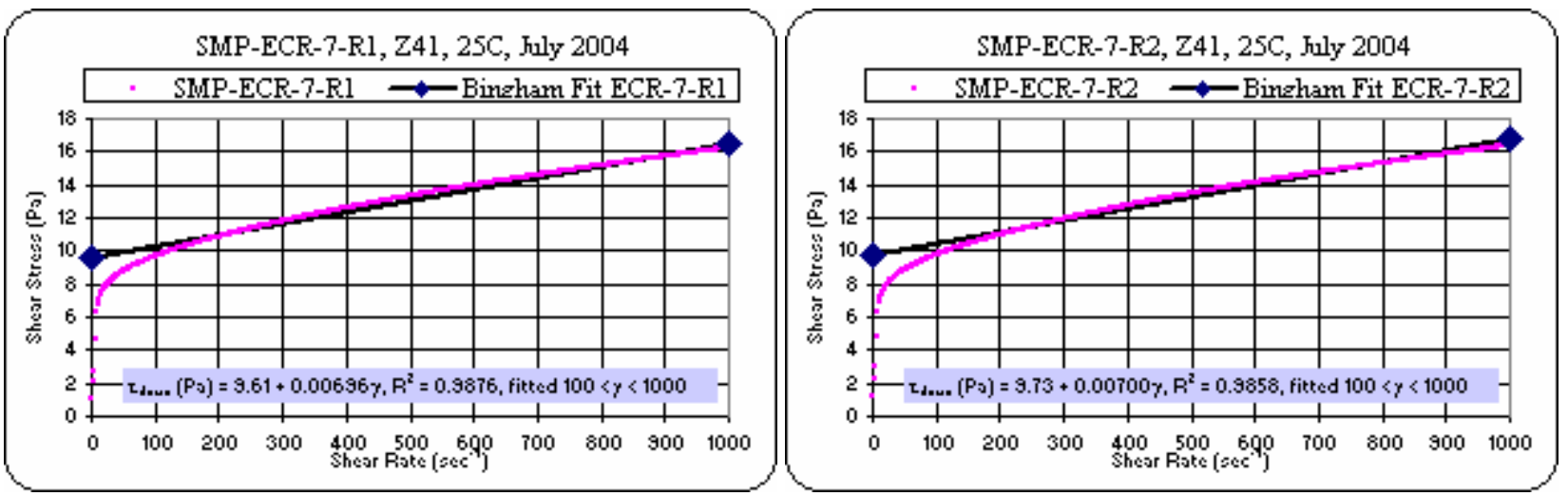

Figure A - 10: Down Flow Curve Sample SMP-ECR-7, July 2004
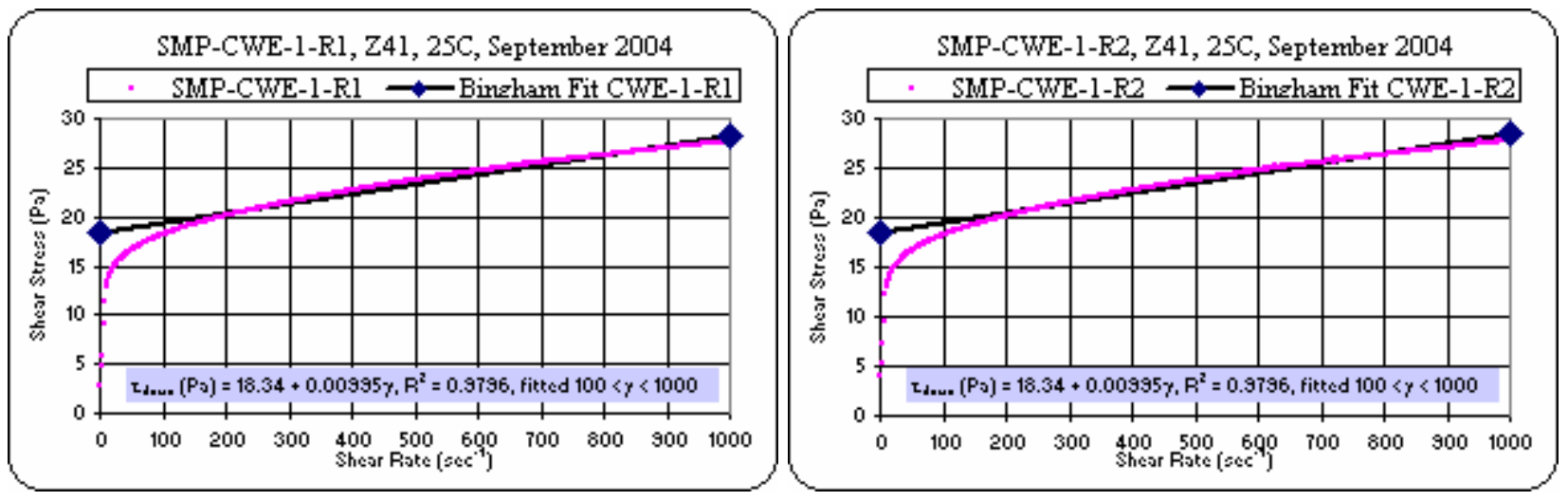

Figure A - 11: Down Flow Curve Sample SMP-CWE-1, September 2004
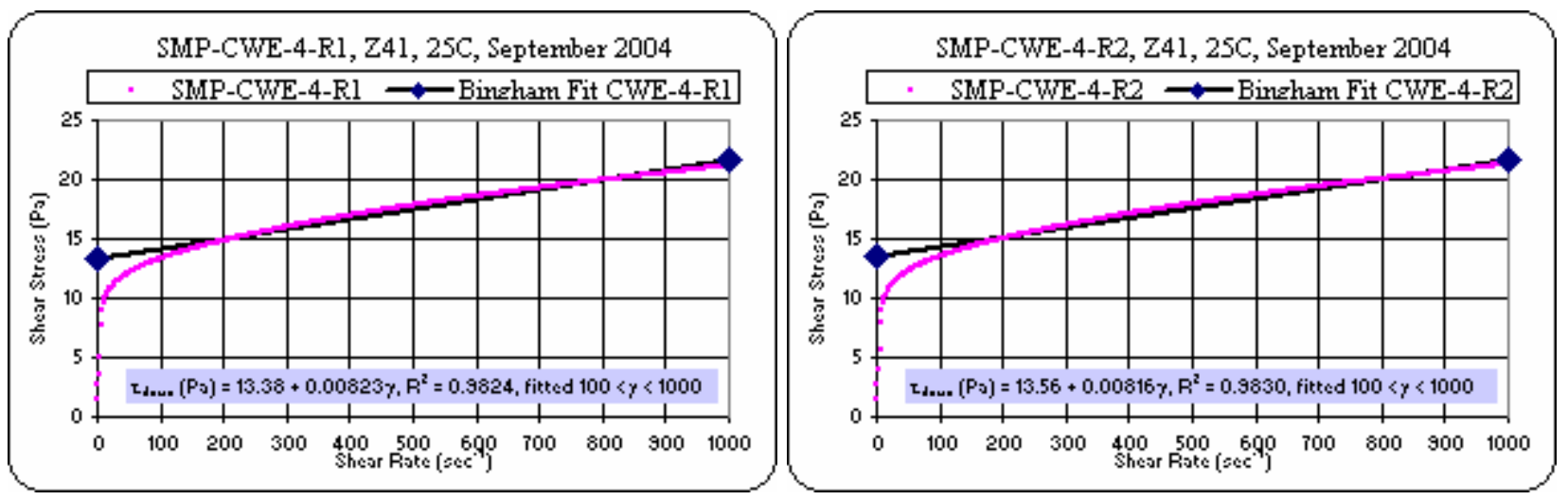

Figure A - 12: Down Flow Curve Sample SMP-CWE-4, September 2004 

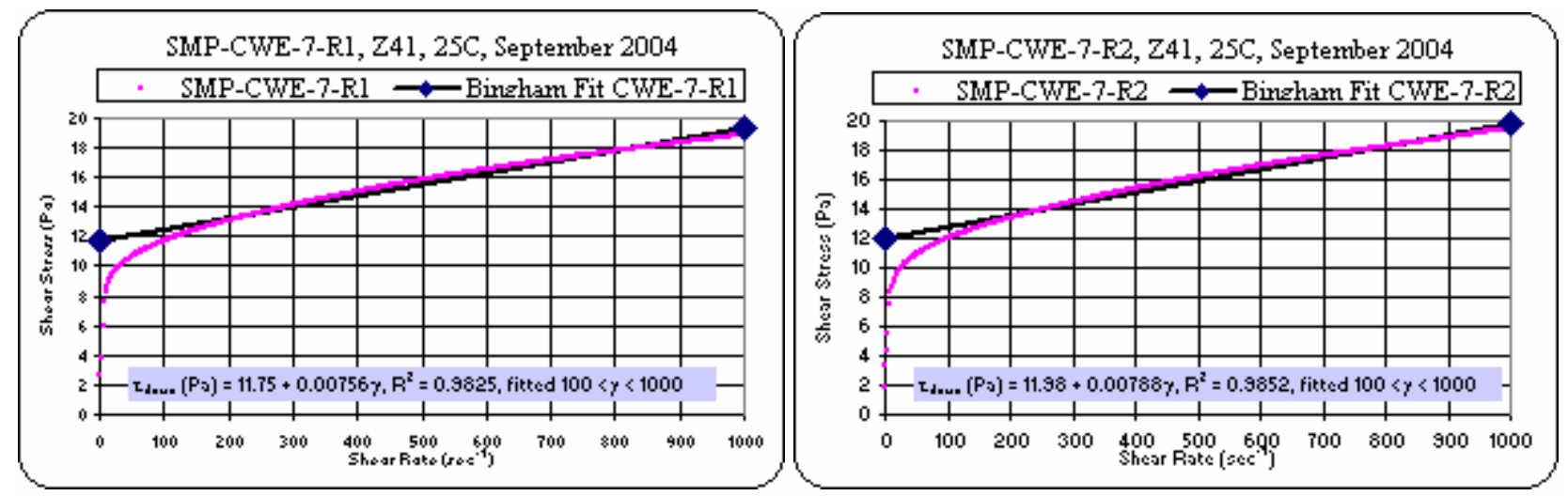

Figure A - 13: Down Flow Curve Sample SMP-CWE-7, September 2004
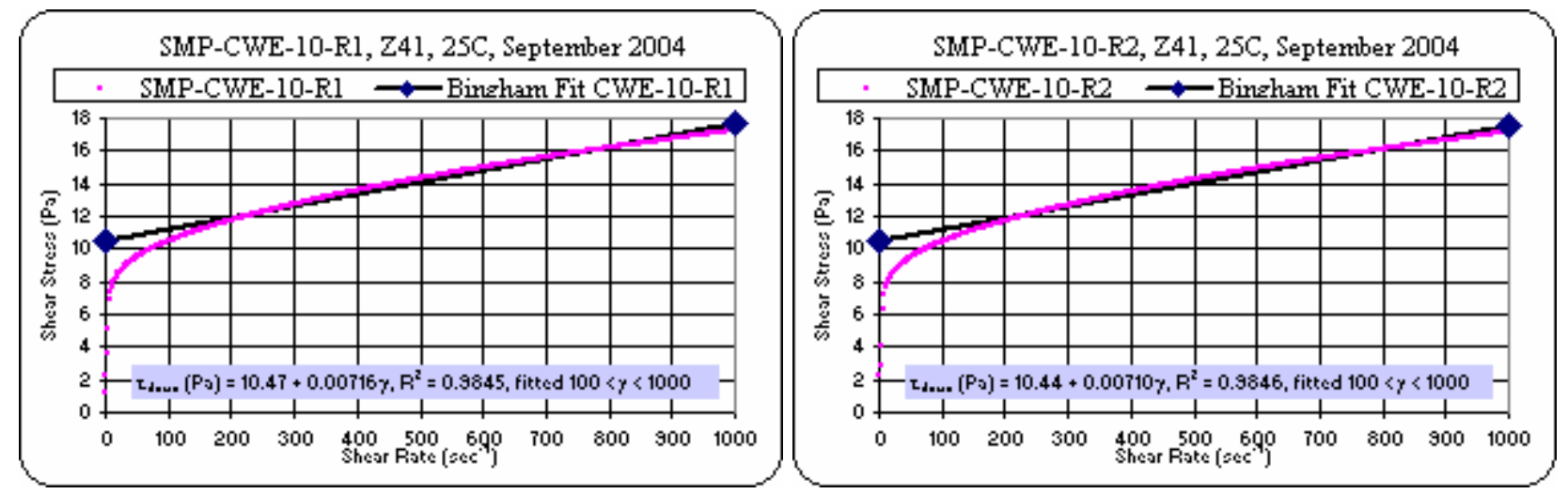

Figure A - 14: Down Flow Curve Sample SMP-CWE-10, September 2004
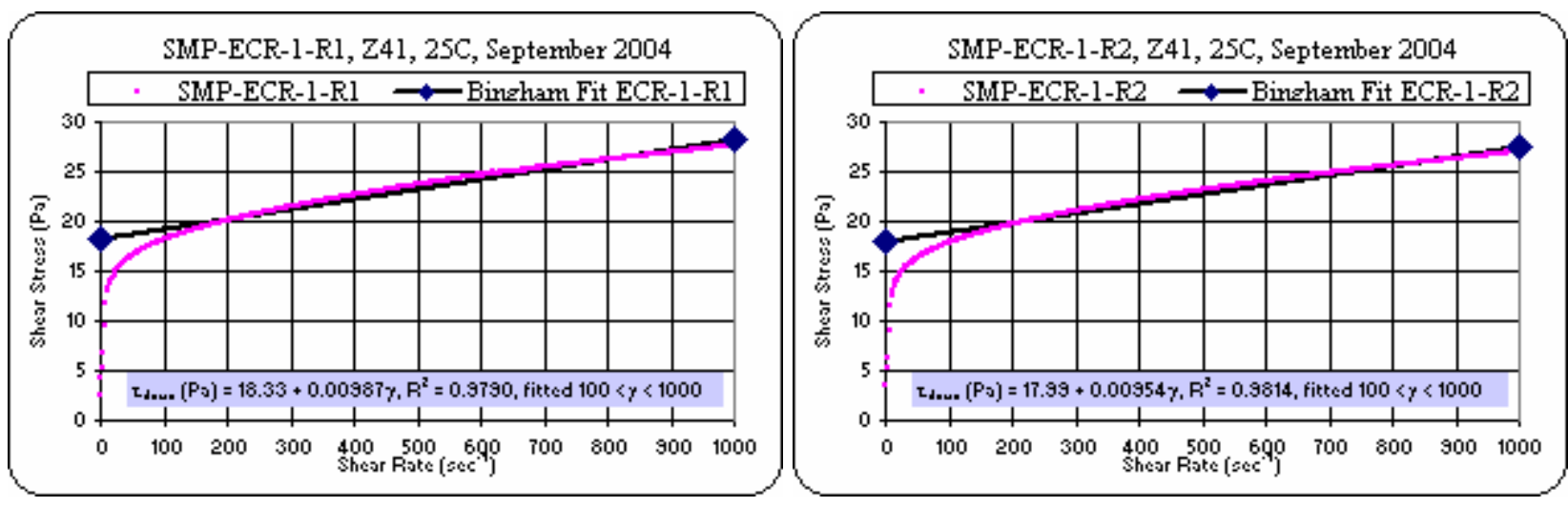

Figure A - 15: Down Flow Curve Sample SMP-ECR-1, September 2004 

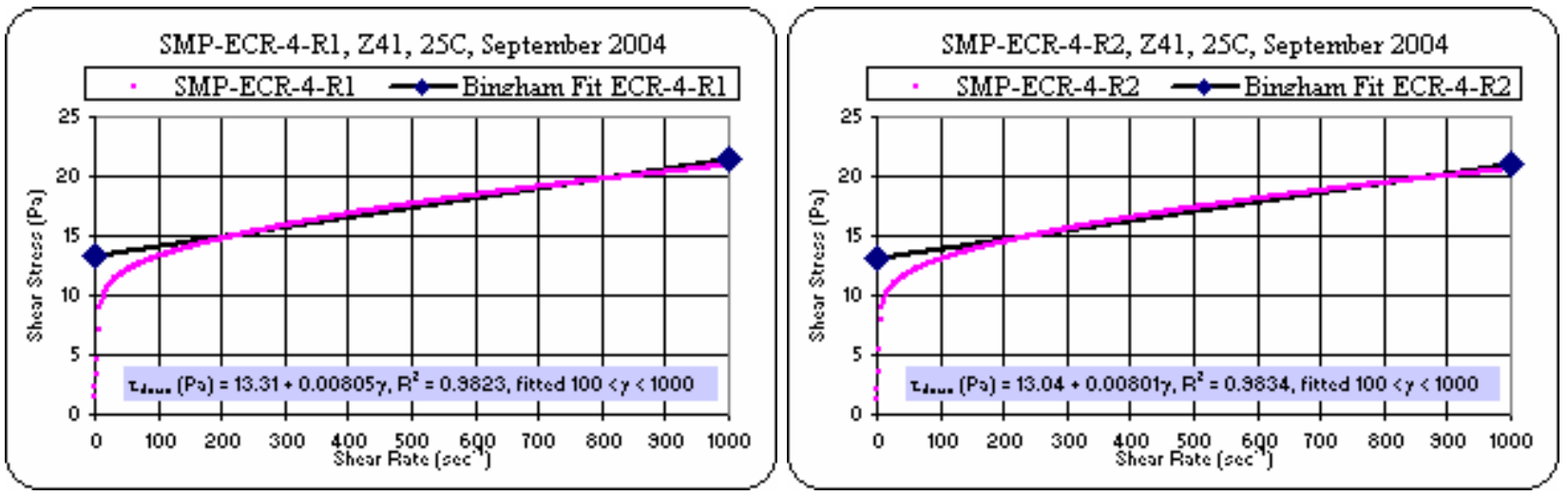

Figure A - 16: Down Flow Curve Sample SMP-ECR-4, September 2004
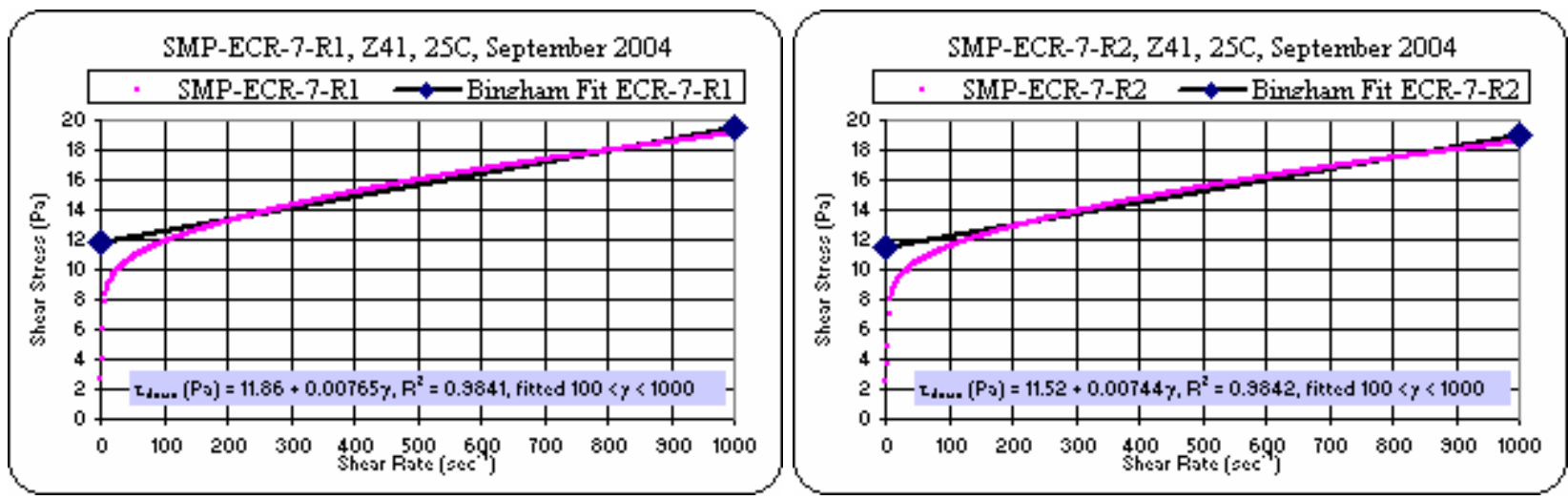

Figure A - 17: Down Flow Curve Sample SMP-ECR-7, September 2004
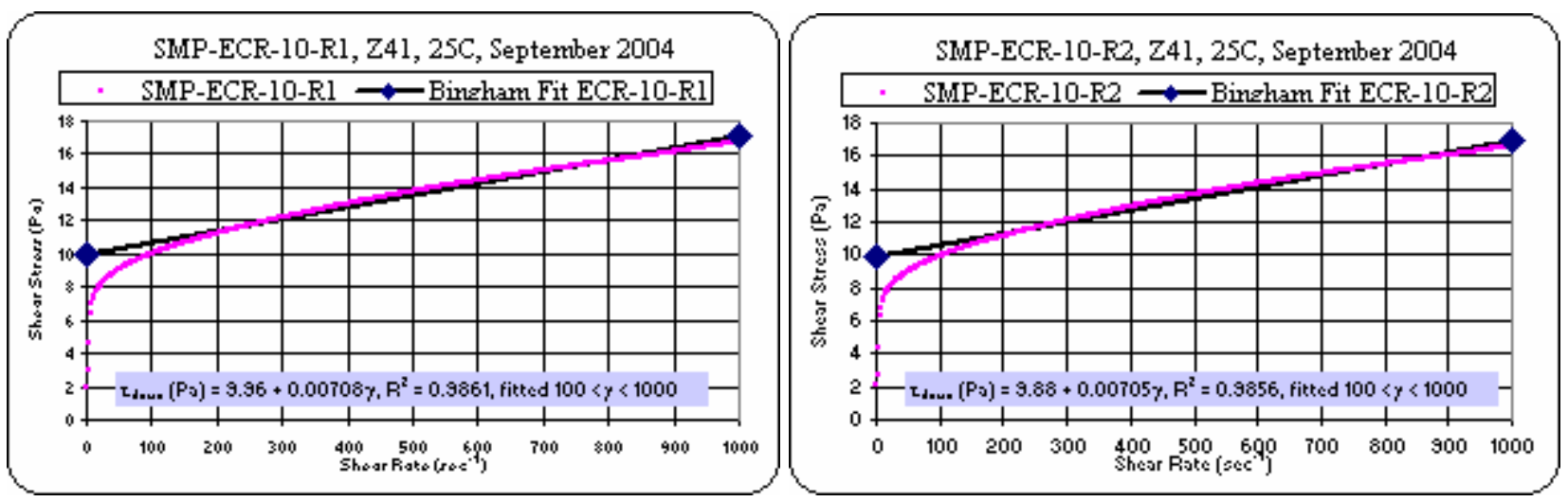

Figure A - 18: Down Flow Curve Sample SMP-ECR-10, September 2004 

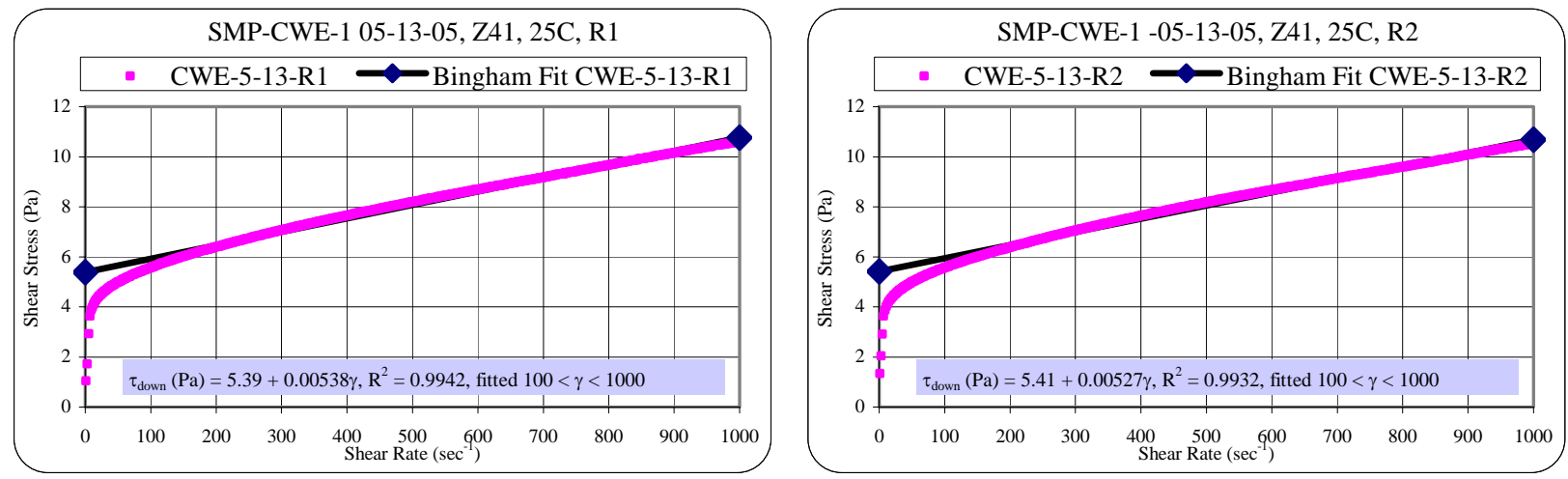

Figure A - 19: Down Flow Curve Sample SMP-CWE-1, May 2005
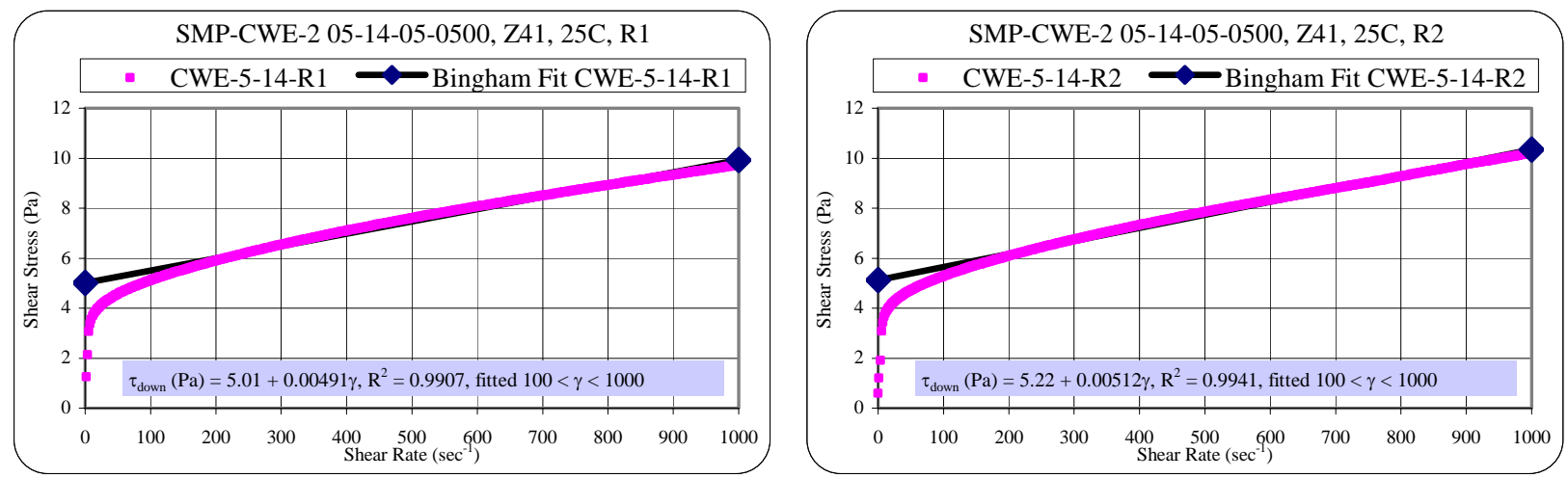

Figure A - 20: Down Flow Curve Sample SMP-CWE-2, May 2005
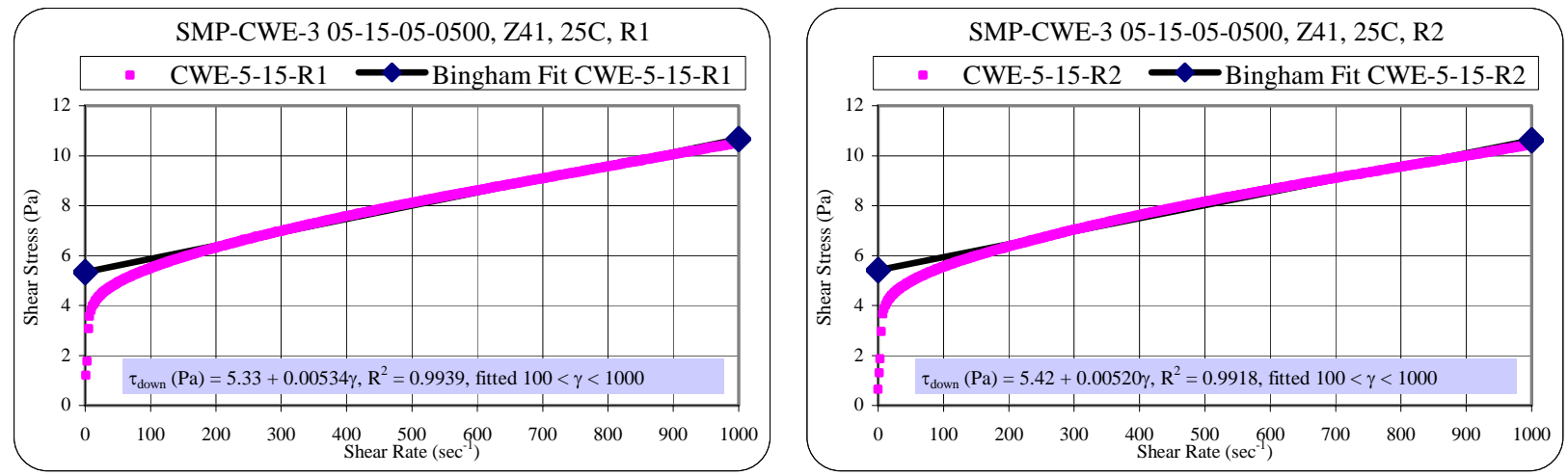

Figure A - 21: Down Flow Curve Sample SMP-CWE-3, May 2005 

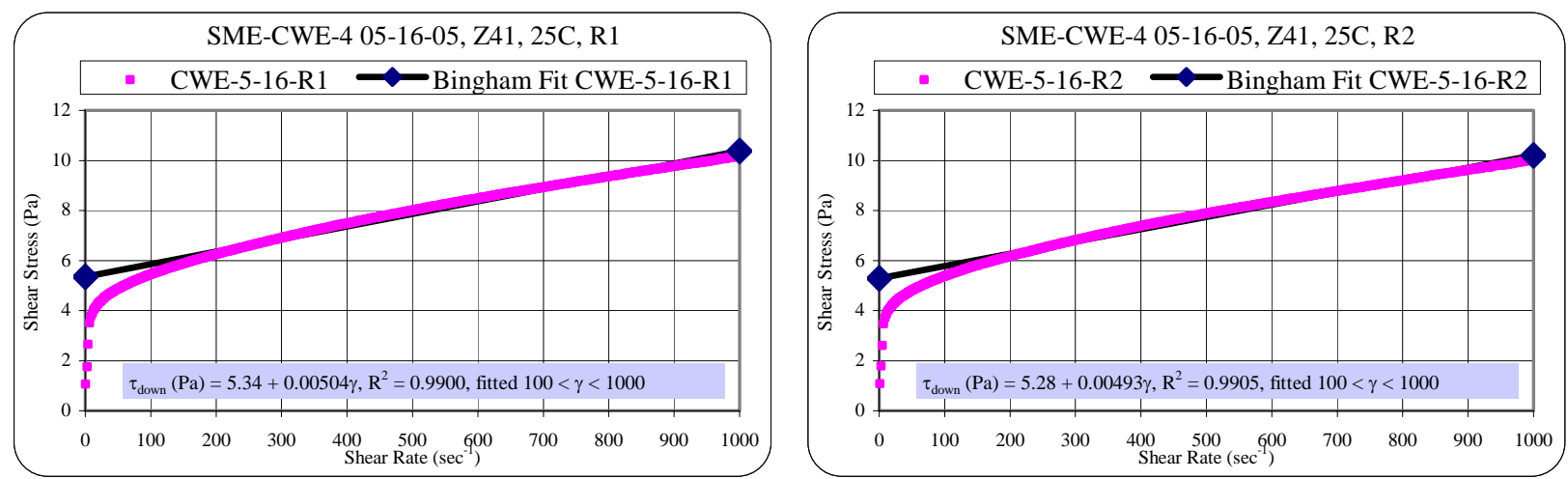

Figure A - 22: Down Flow Curve Sample SMP-CWE-4, May 2005
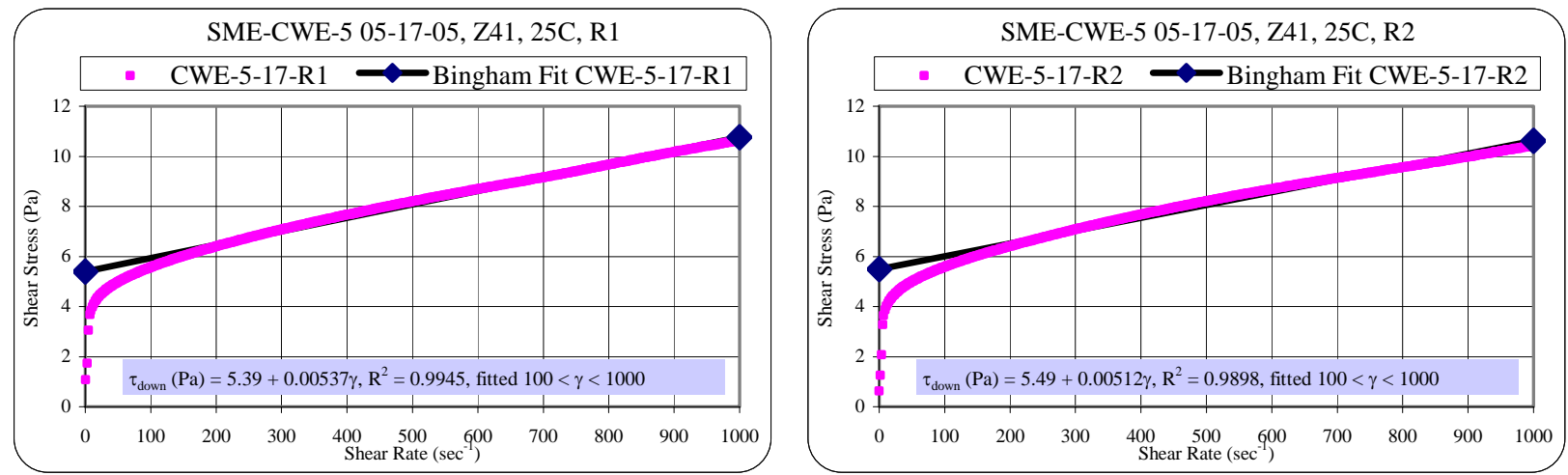

Figure A - 23: Down Flow Curve Sample SMP-CWE-5, May 2005
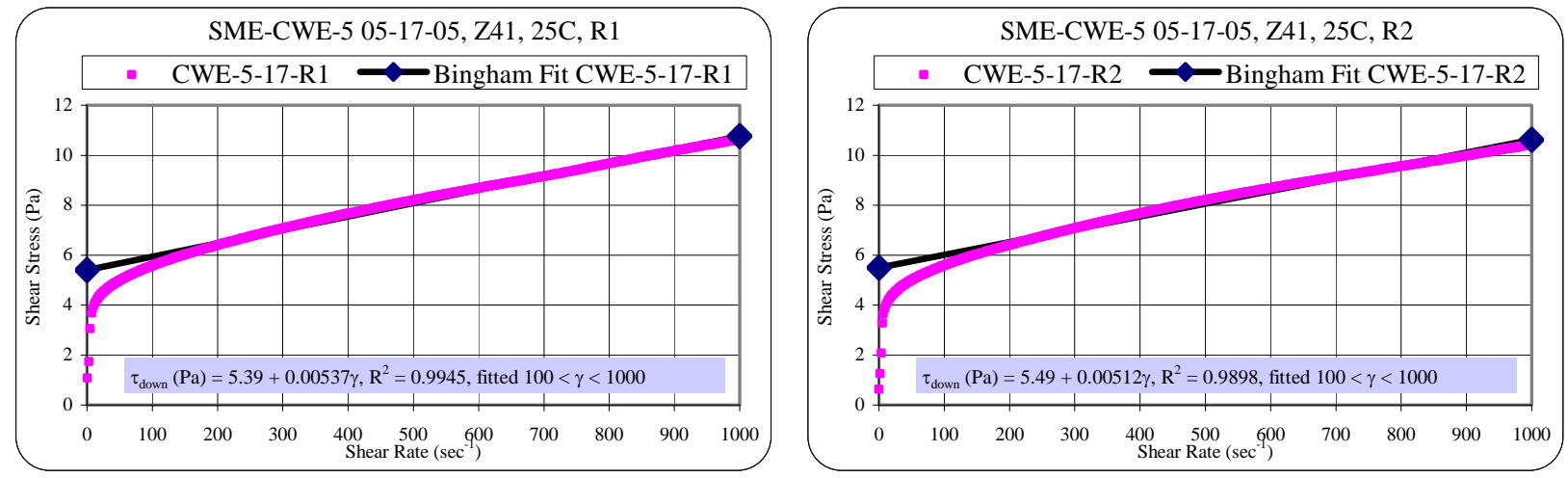

Figure A - 24: Down Flow Curve Sample SMP-CWE-6, May 2005 

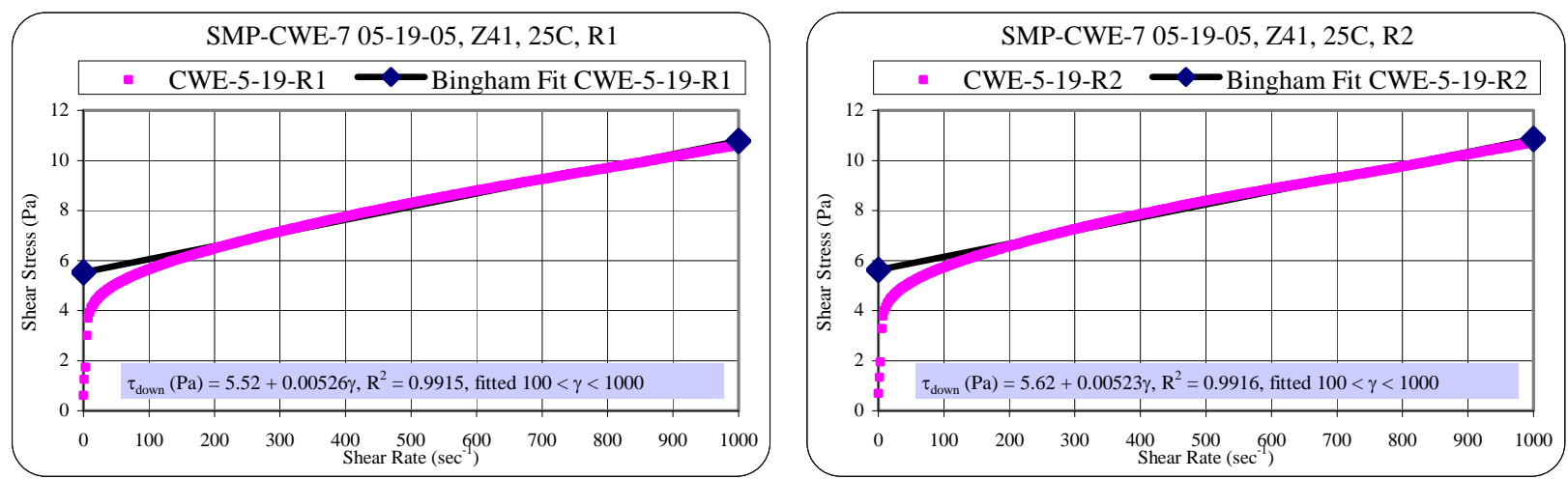

Figure A - 25: Down Flow Curve Sample SMP-CWE-7, May 2005
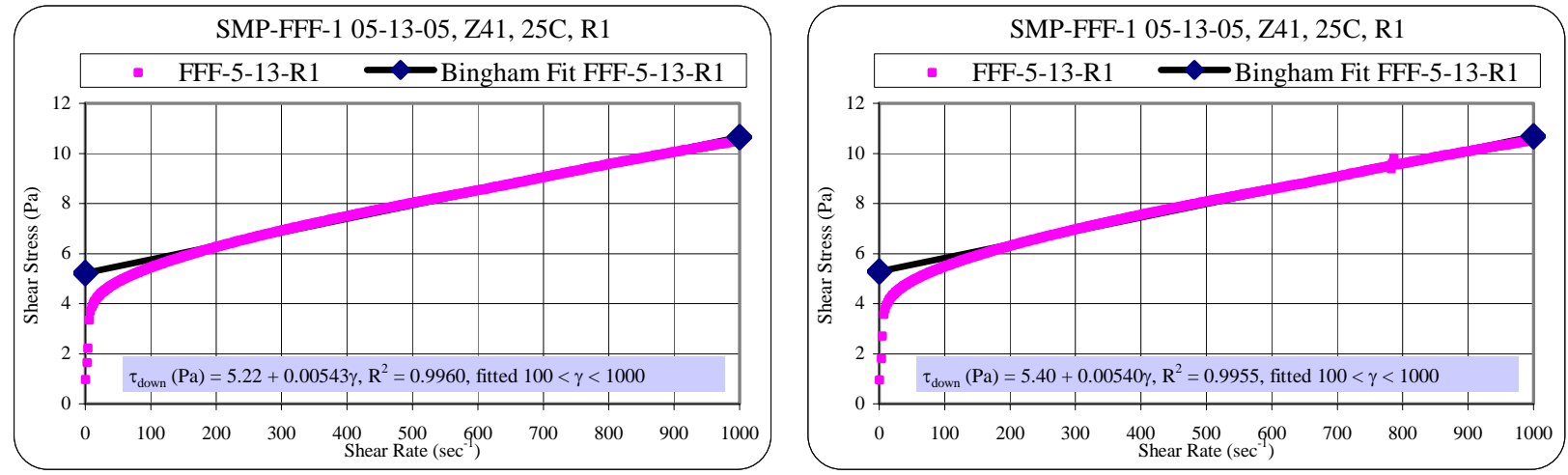

Figure A - 26: Down Flow Curve Sample SMP-FFF-1, May 2005
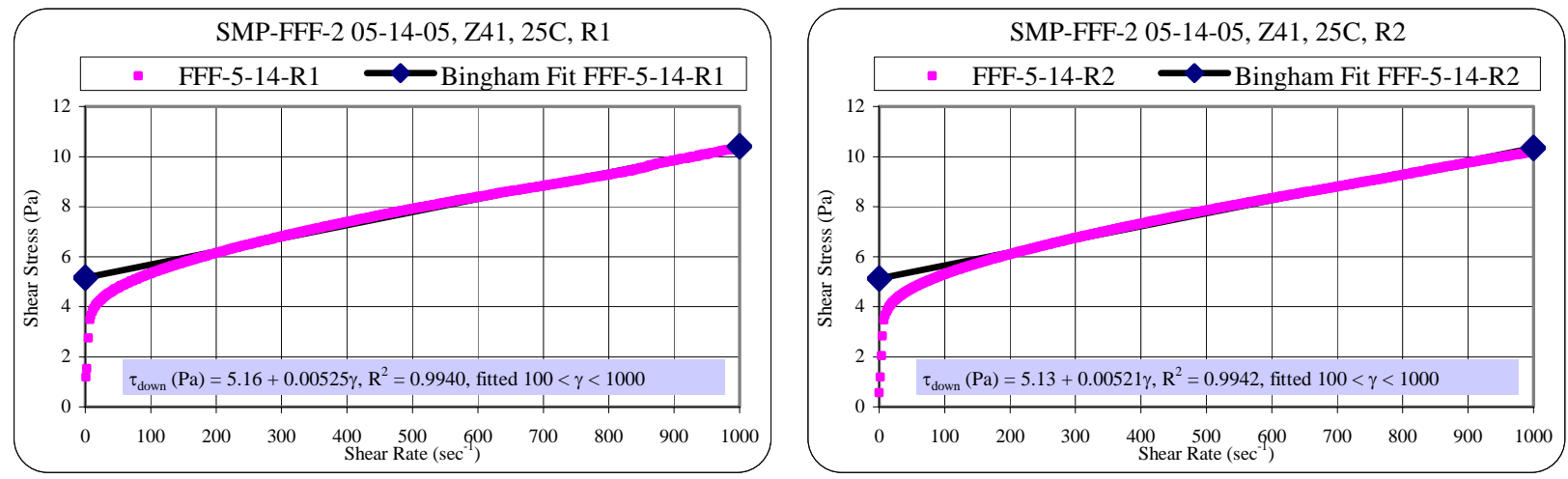

Figure A - 27: Down Flow Curve Sample SMP-FFF-2, May 2005 

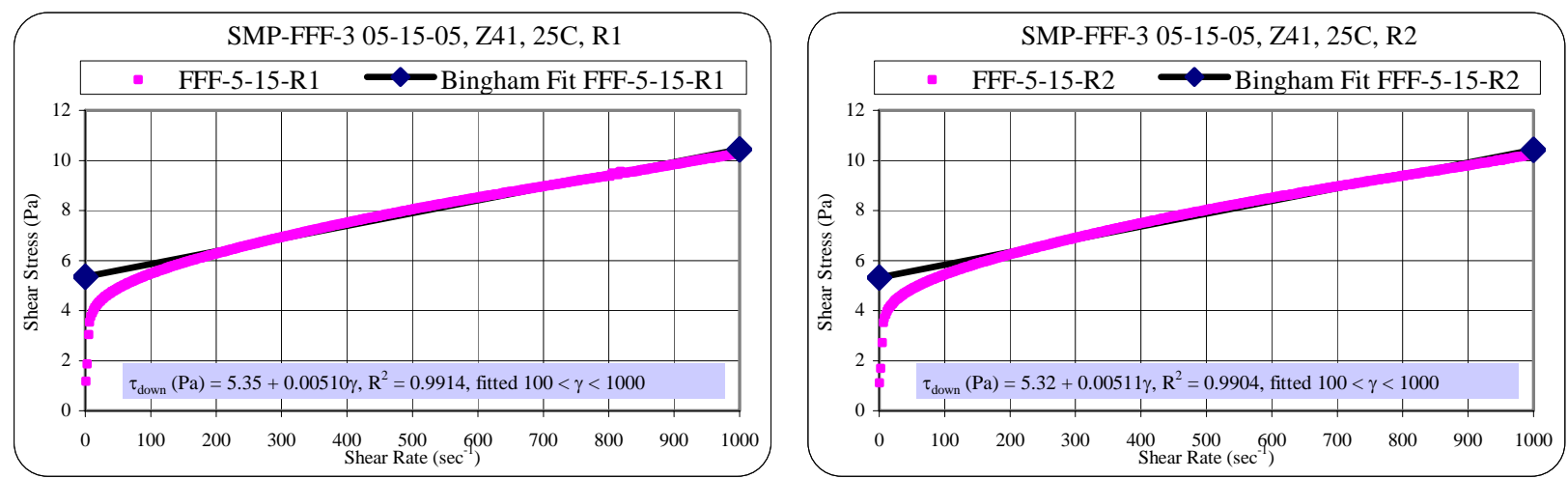

Figure A - 28: Down Flow Curve Sample SMP-FFF-3, May 2005
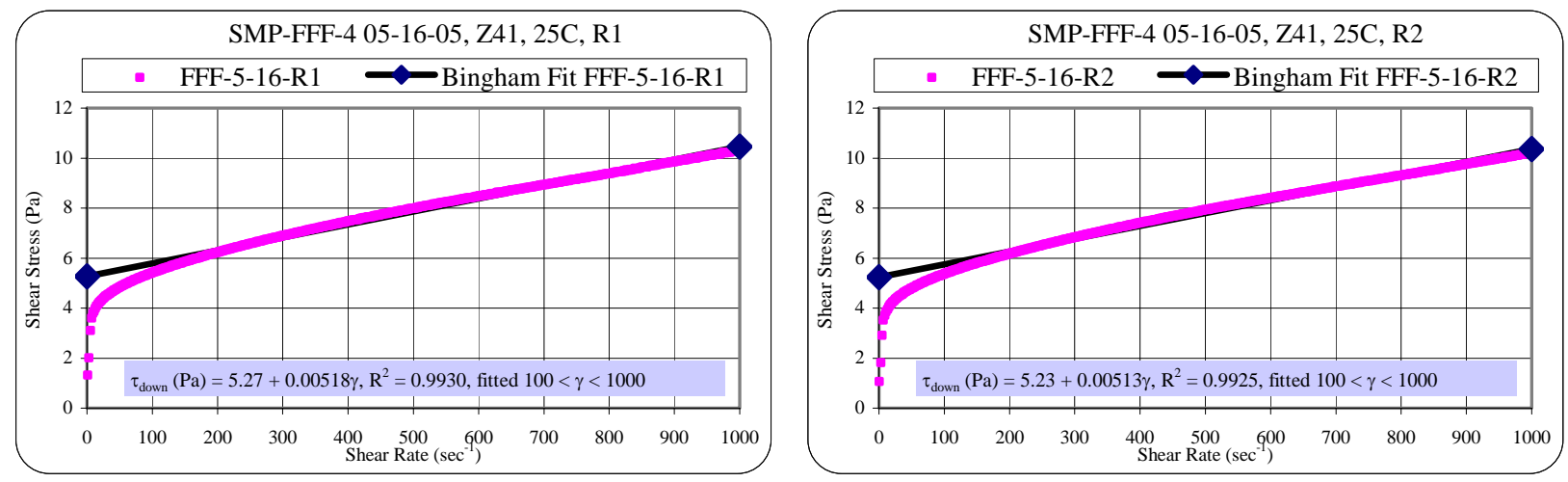

Figure A - 29: Down Flow Curve Sample SMP-FFF-4, May 2005
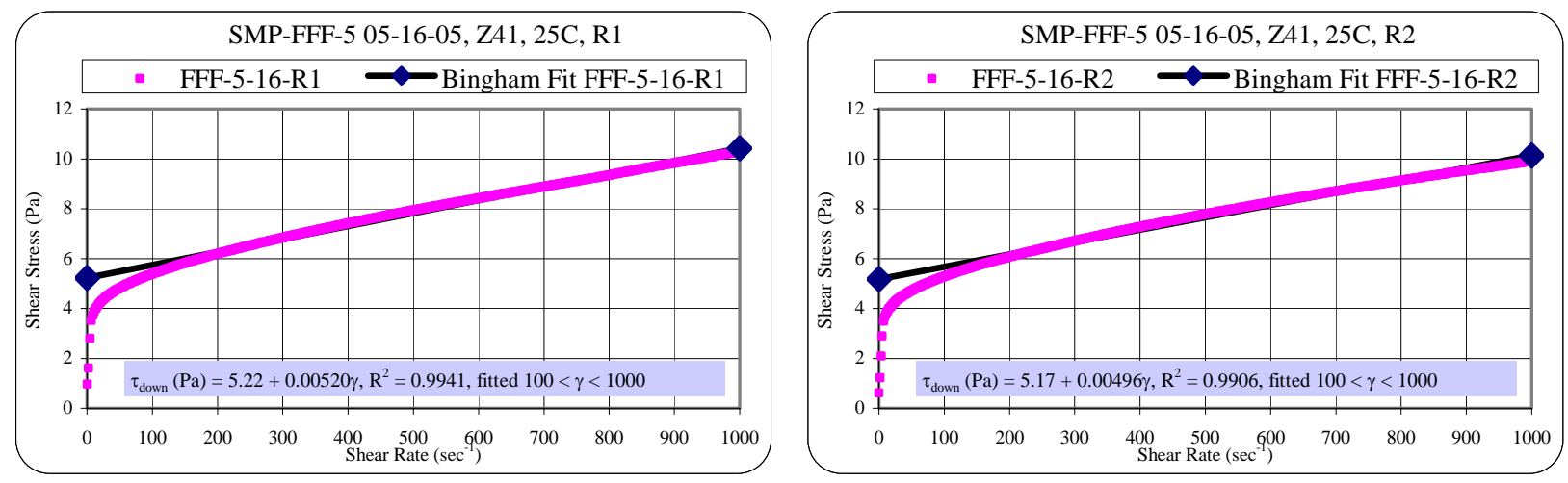

Figure A - 30: Down Flow Curve Sample SMP-FFF-5, May 2005 

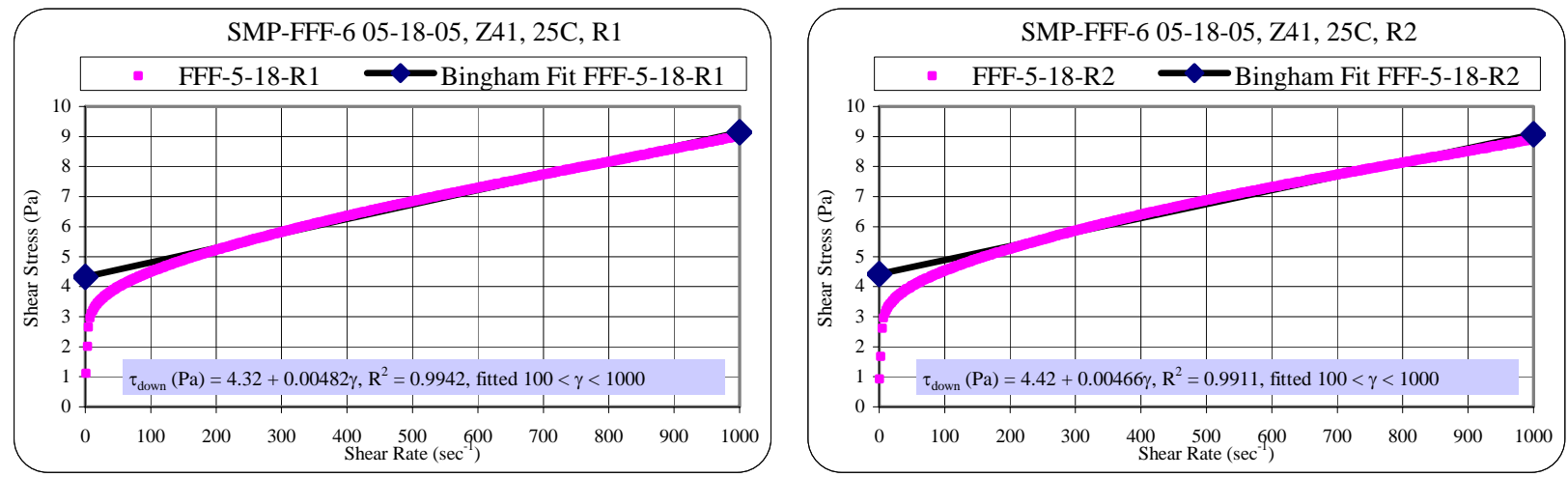

Figure A - 31: Down Flow Curve Sample SMP-FFF-6, May 2005
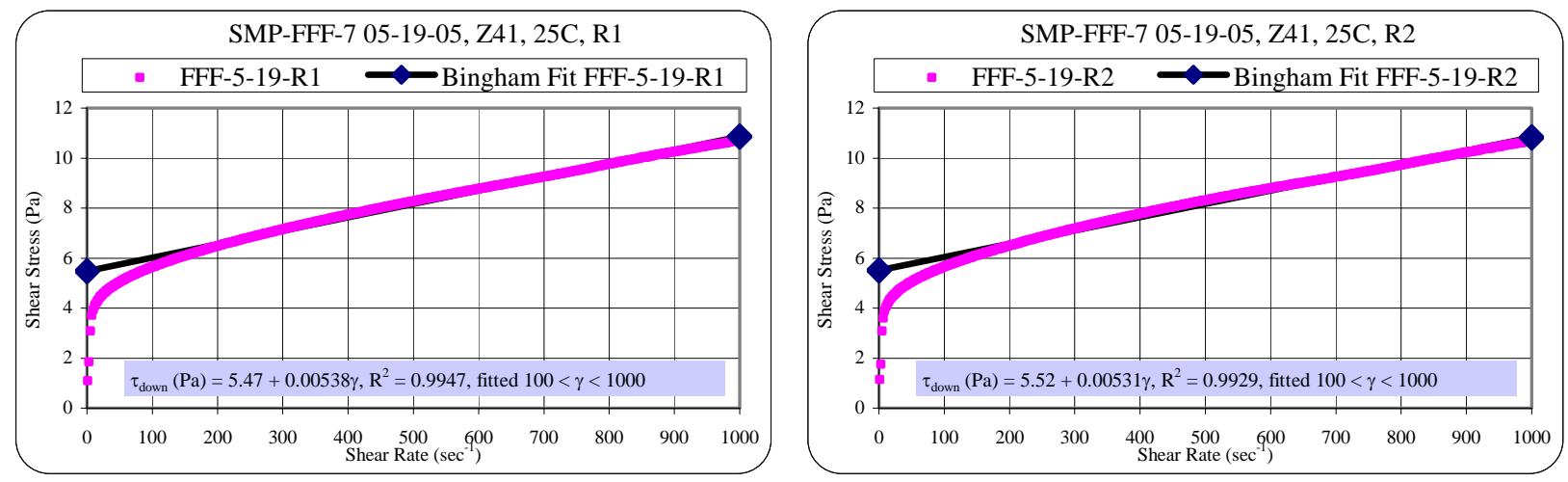

Figure A - 32: Down Flow Curve Sample SMP-FFF-7, May 2005
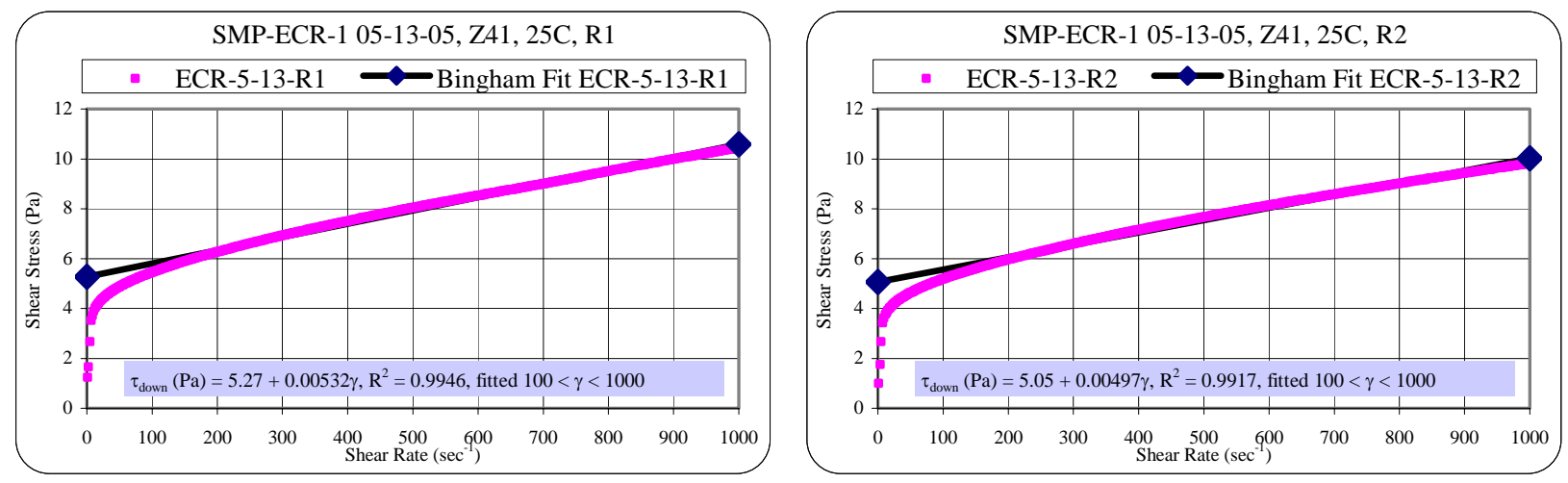

Figure A - 33: Down Flow Curve Sample SMP-ECR-1, May 2005 

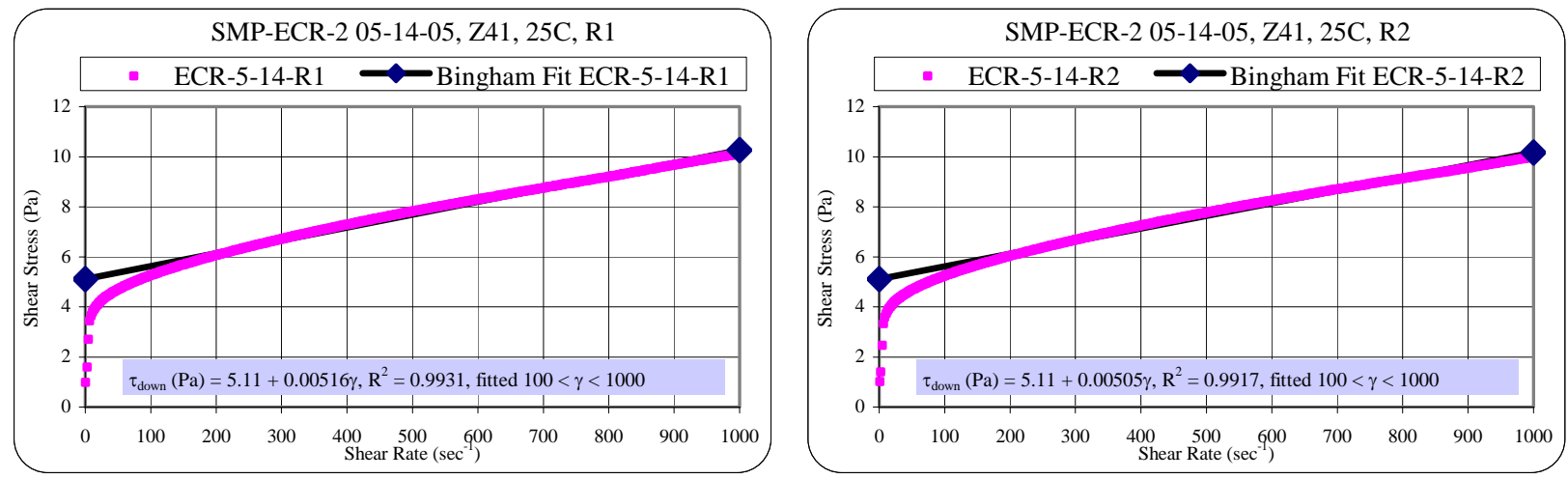

Figure A - 34: Down Flow Curve Sample SMP-ECR-2, May 2005
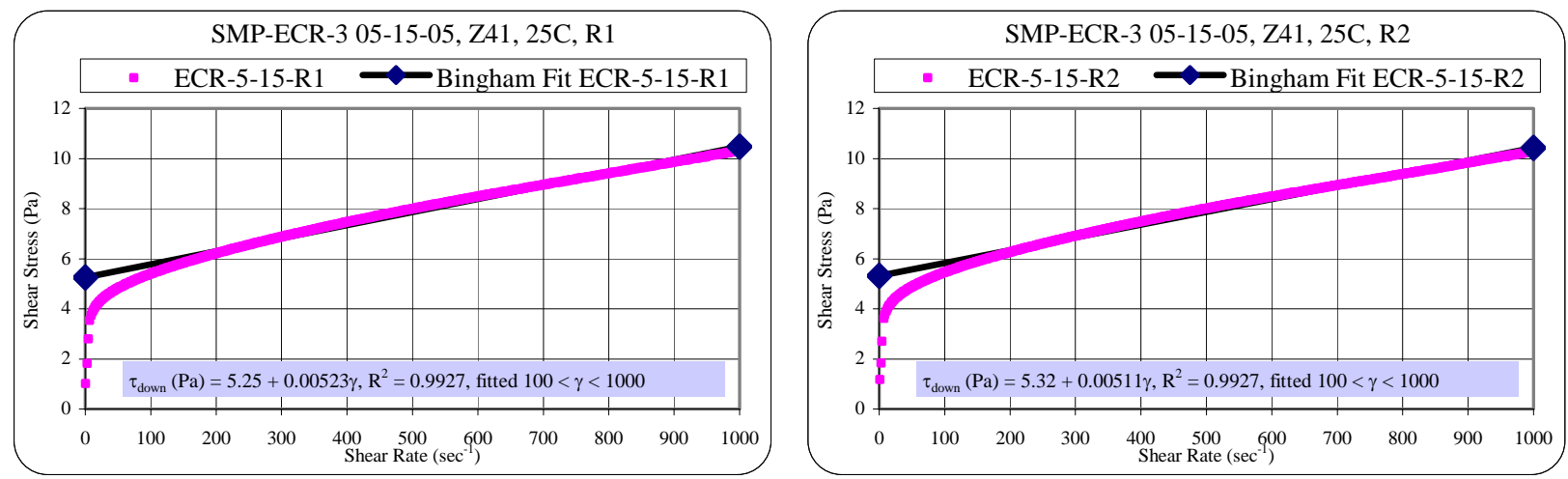

Figure A - 35: Down Flow Curve Sample SMP-ECR-3, May 2005
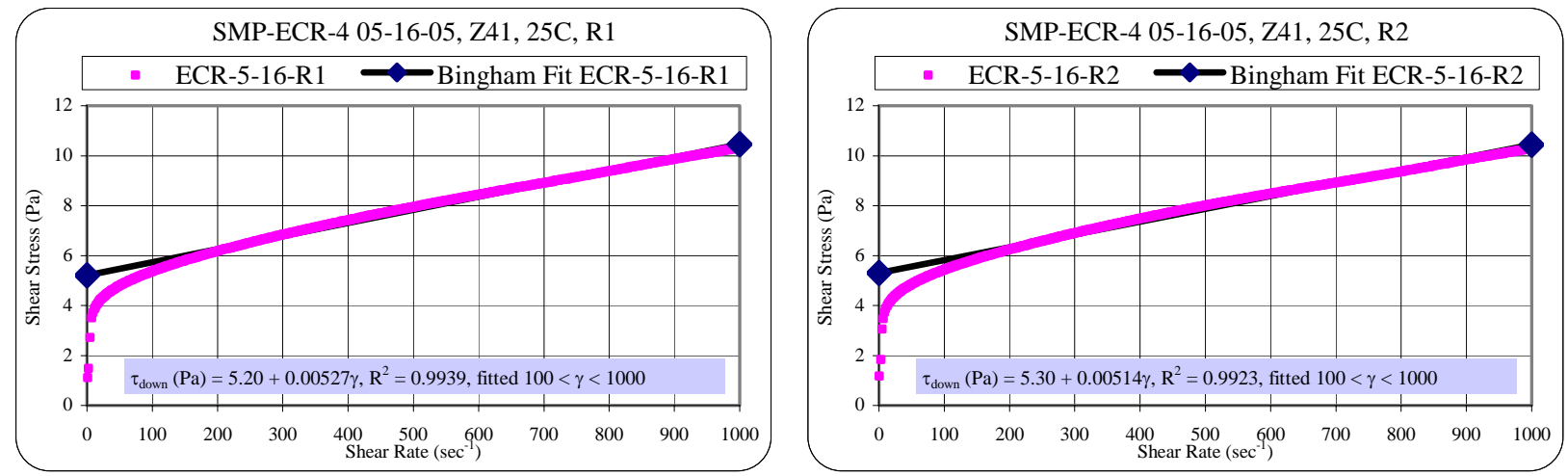

Figure A - 36: Down Flow Curve Sample SMP-ECR-4, May 2005 

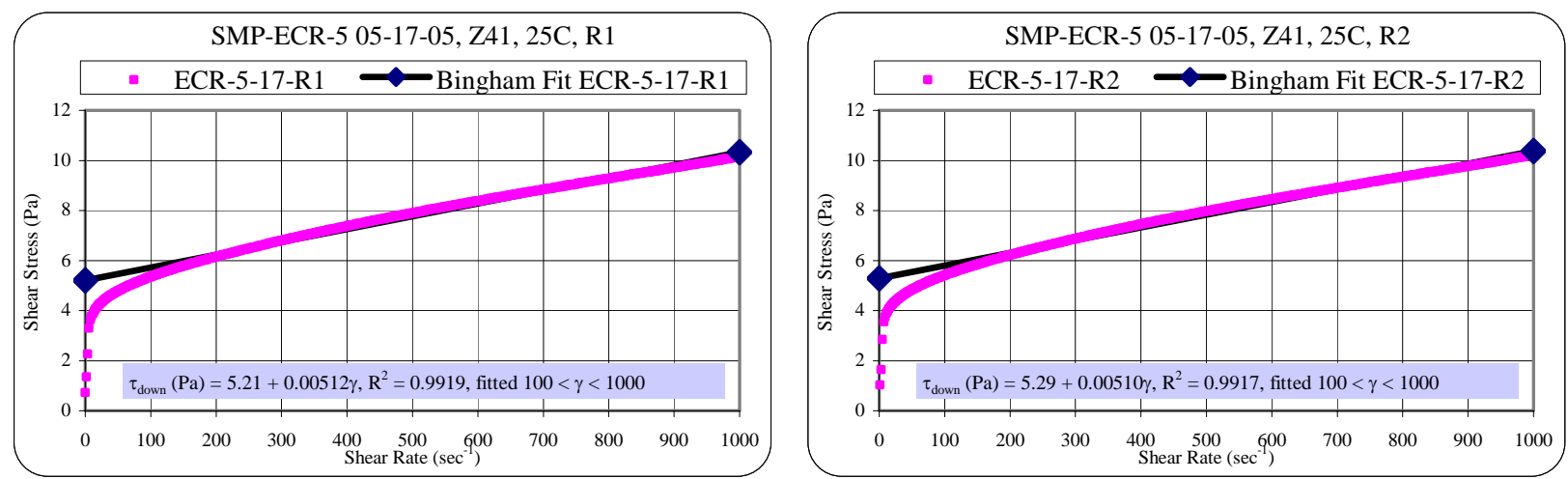

Figure A - 37: Down Flow Curve Sample SMP-ECR-5, May 2005
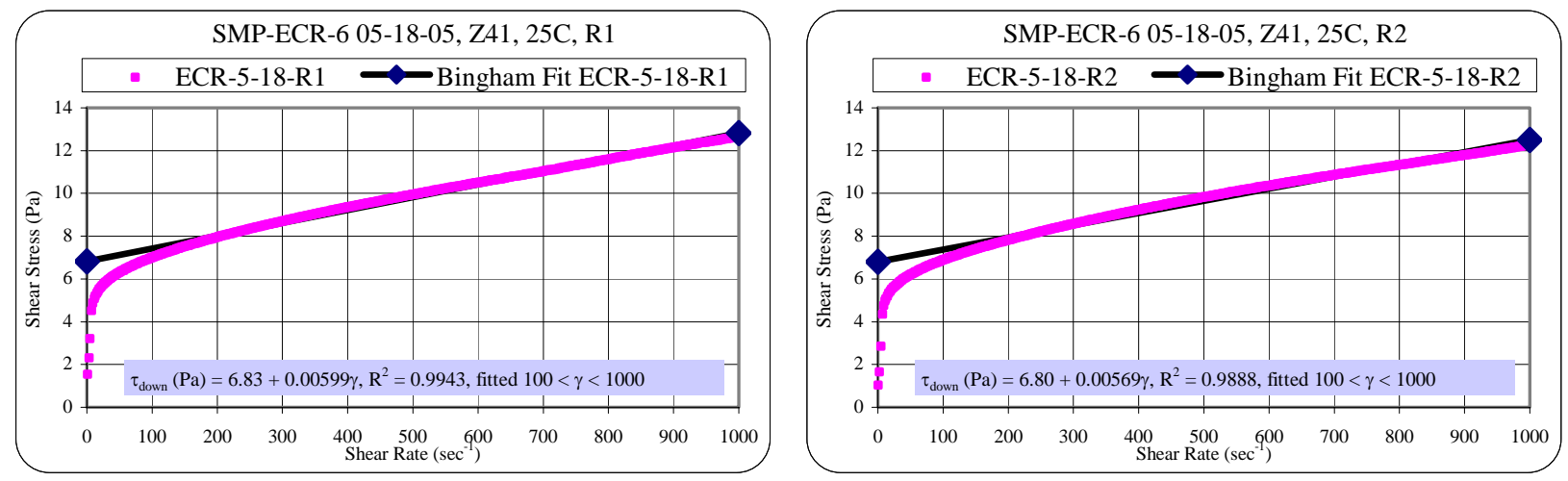

Figure A - 38: Down Flow Curve Sample SMP-ECR-6, May 2005
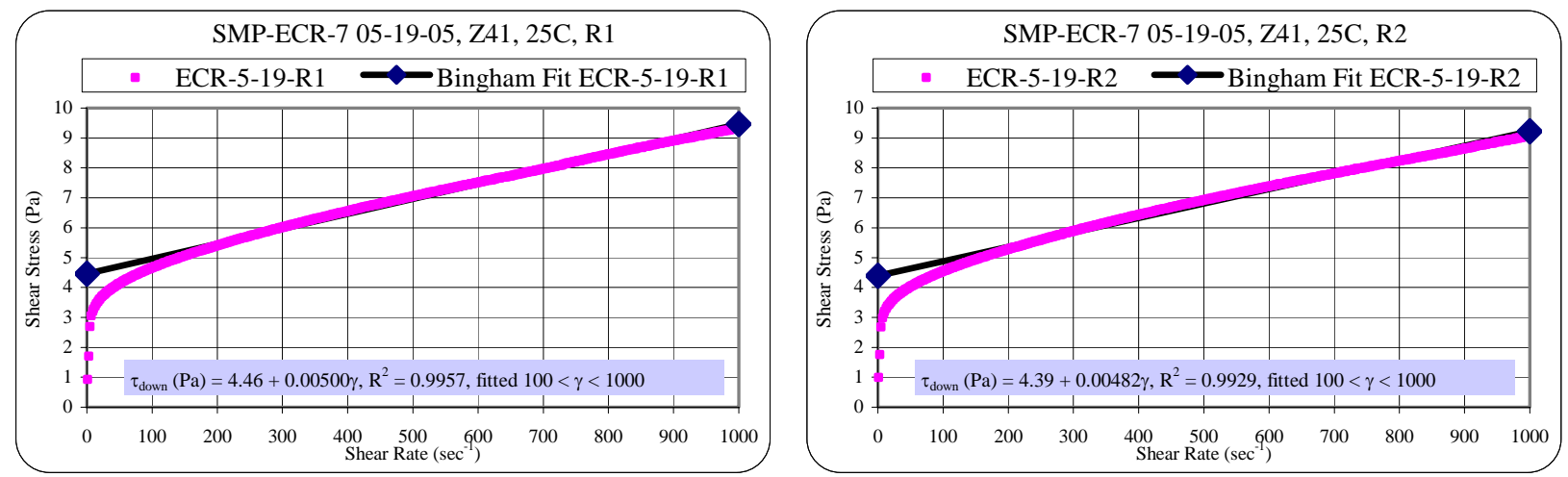

Figure A - 39: Down Flow Curve Sample SMP-ECR-7, May 2005 
WSRC-TR-2004-00401

Revision 1

\section{APPENDIX B. S3000 PARTICLE SIZE DISTRIBUTUION}



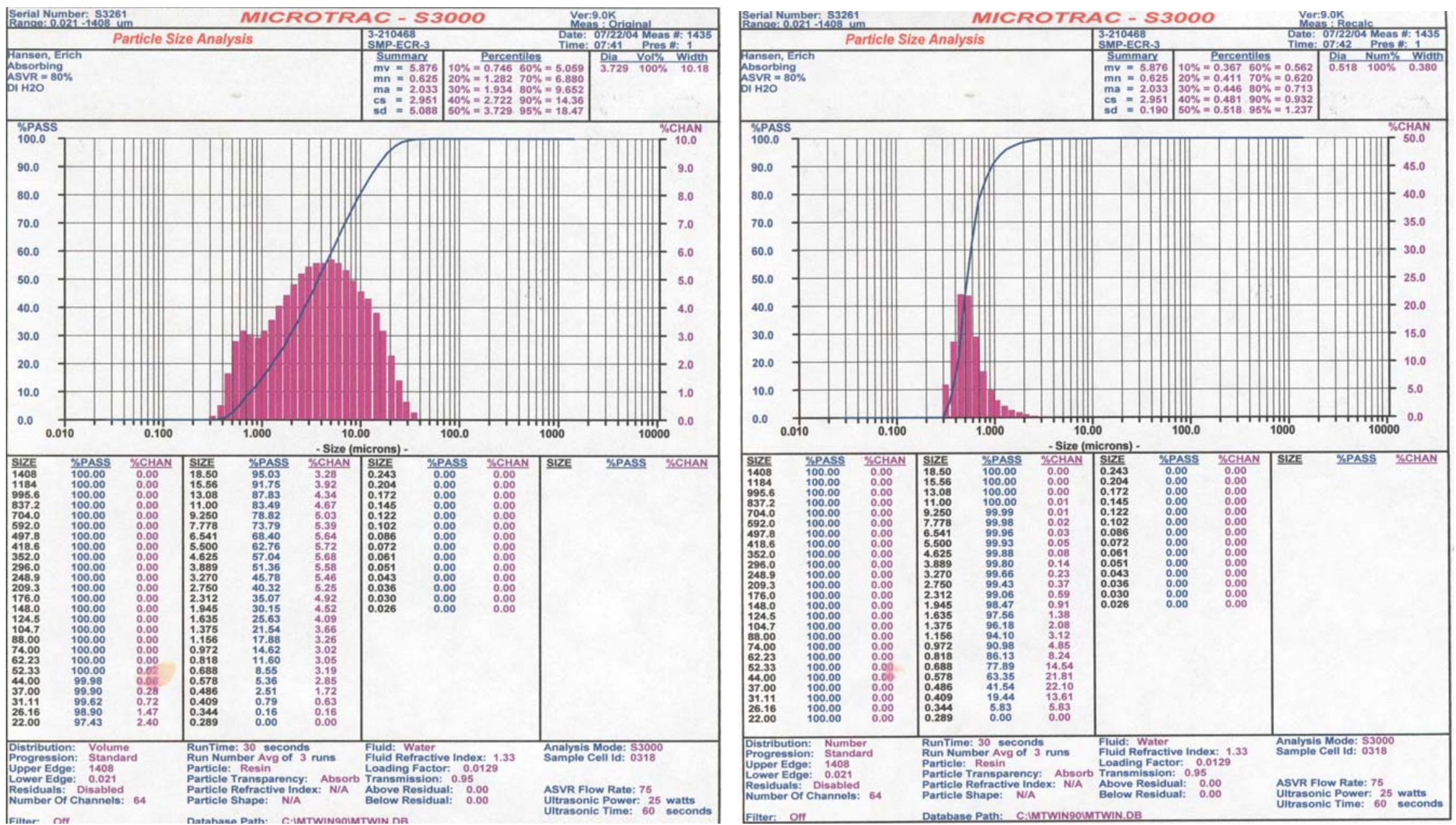

Figure B - 1: July 2004, SMP-ECR-3 Volume and Number Distribution 

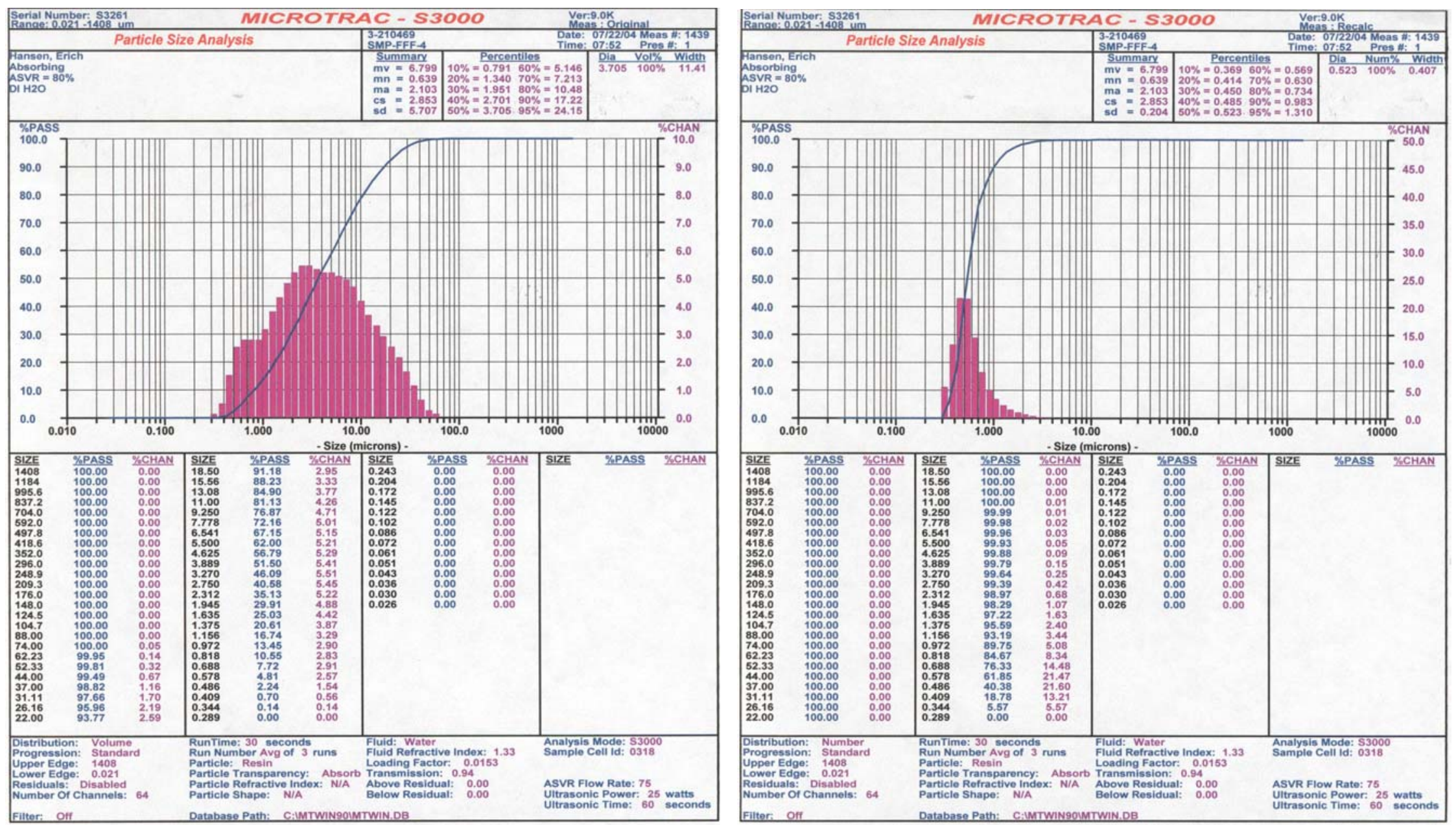

Figure B - 2: July 2004, SMP-FFF-4 Volume and Number Distribution 

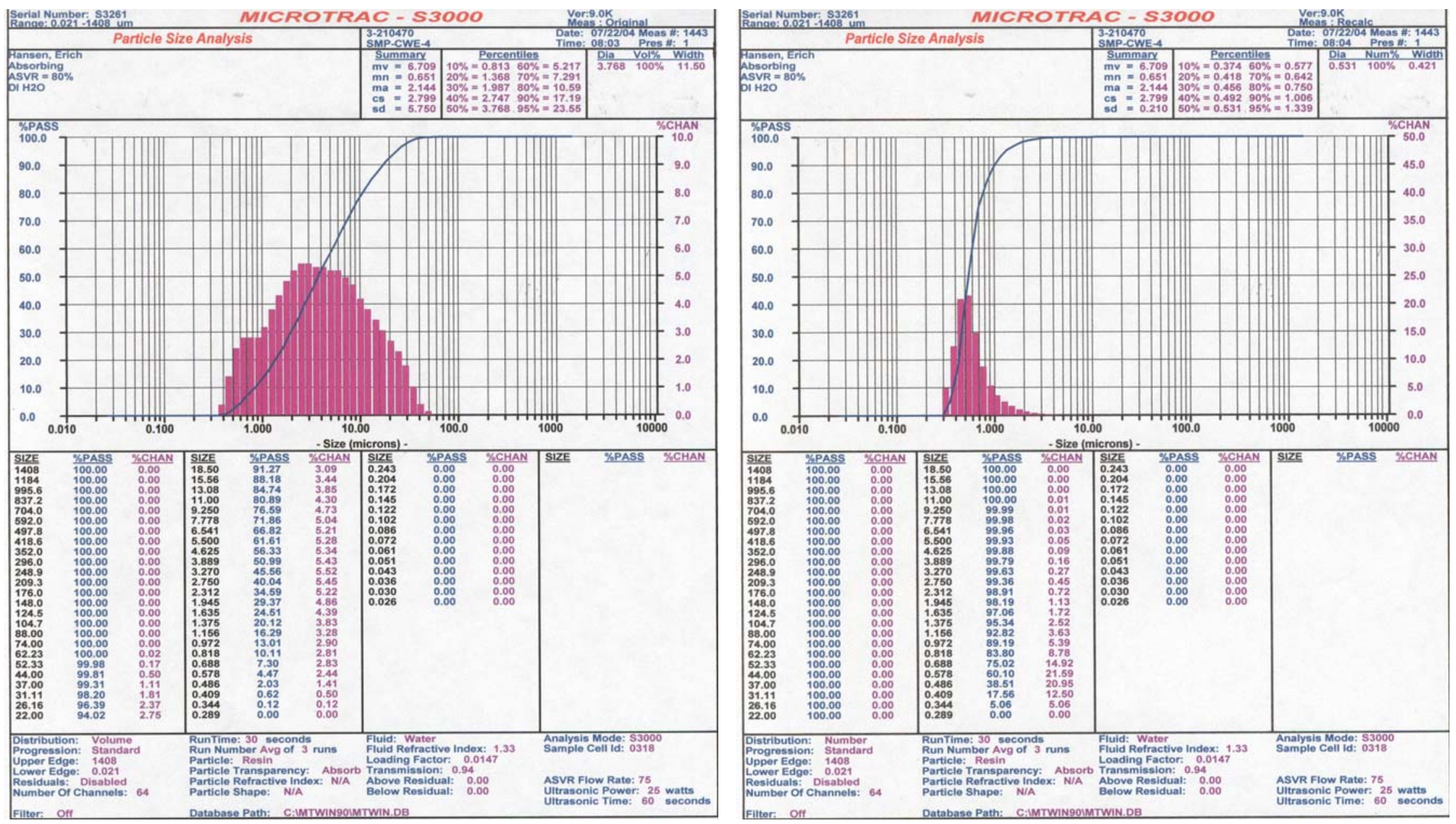

Figure B - 3: July 2004, SMP-CWE-4 Volume and Number Distribution 

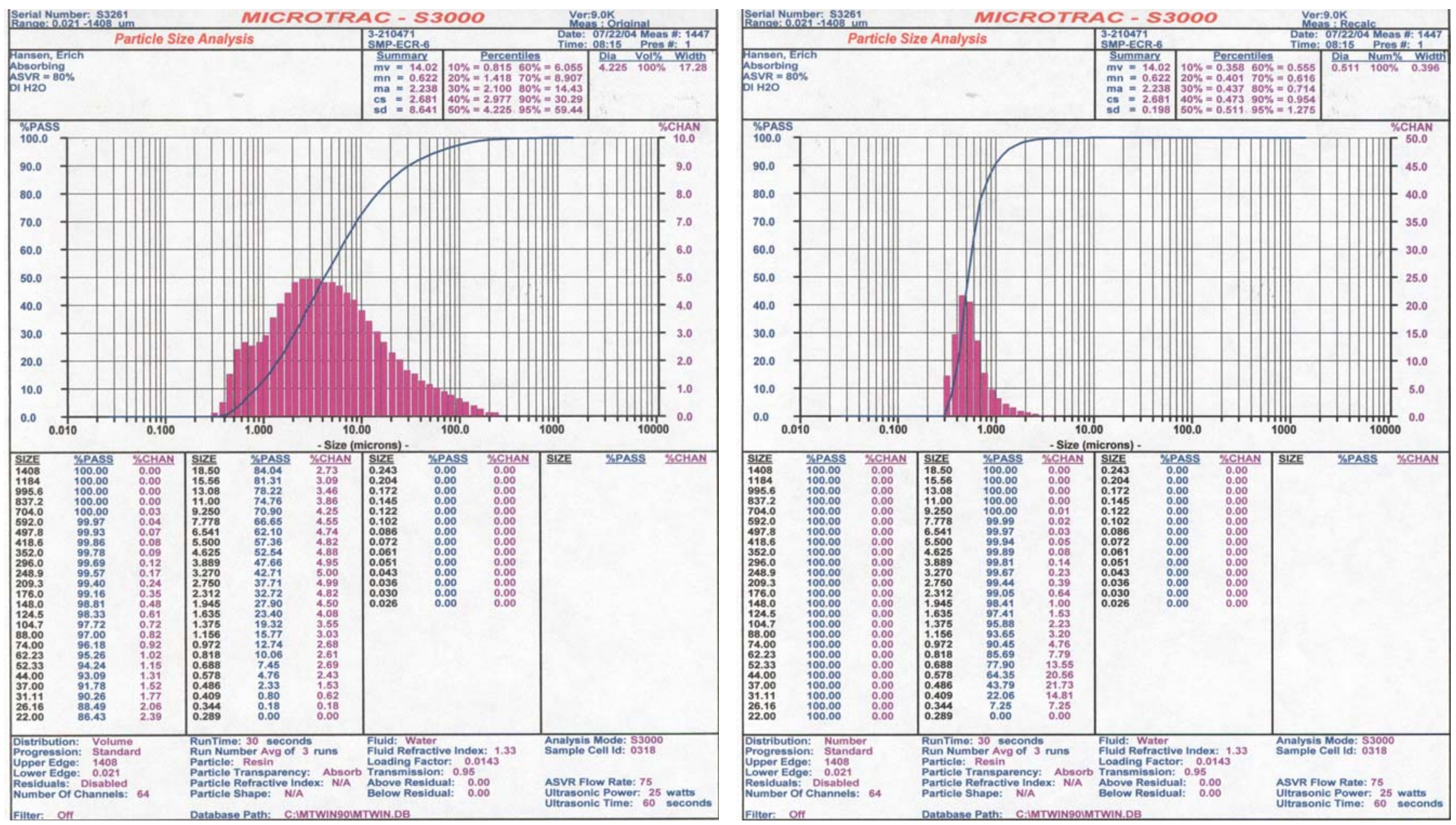

Figure B - 4: July 2004, SMP-ECR-6 Volume and Number Distribution 

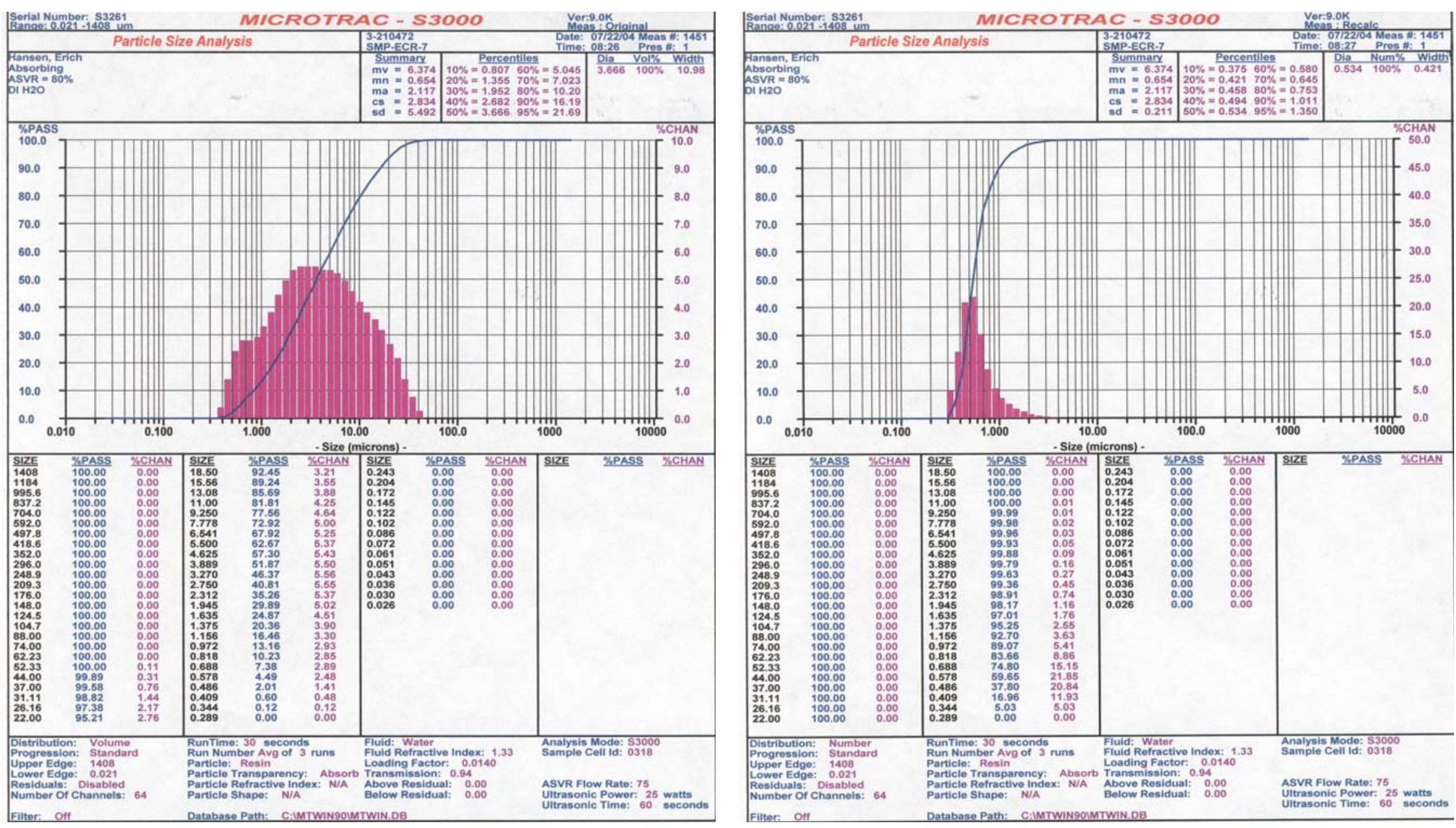

Figure B - 5: July 2004, SMP-ECR-7 Volume and Number Distribution 

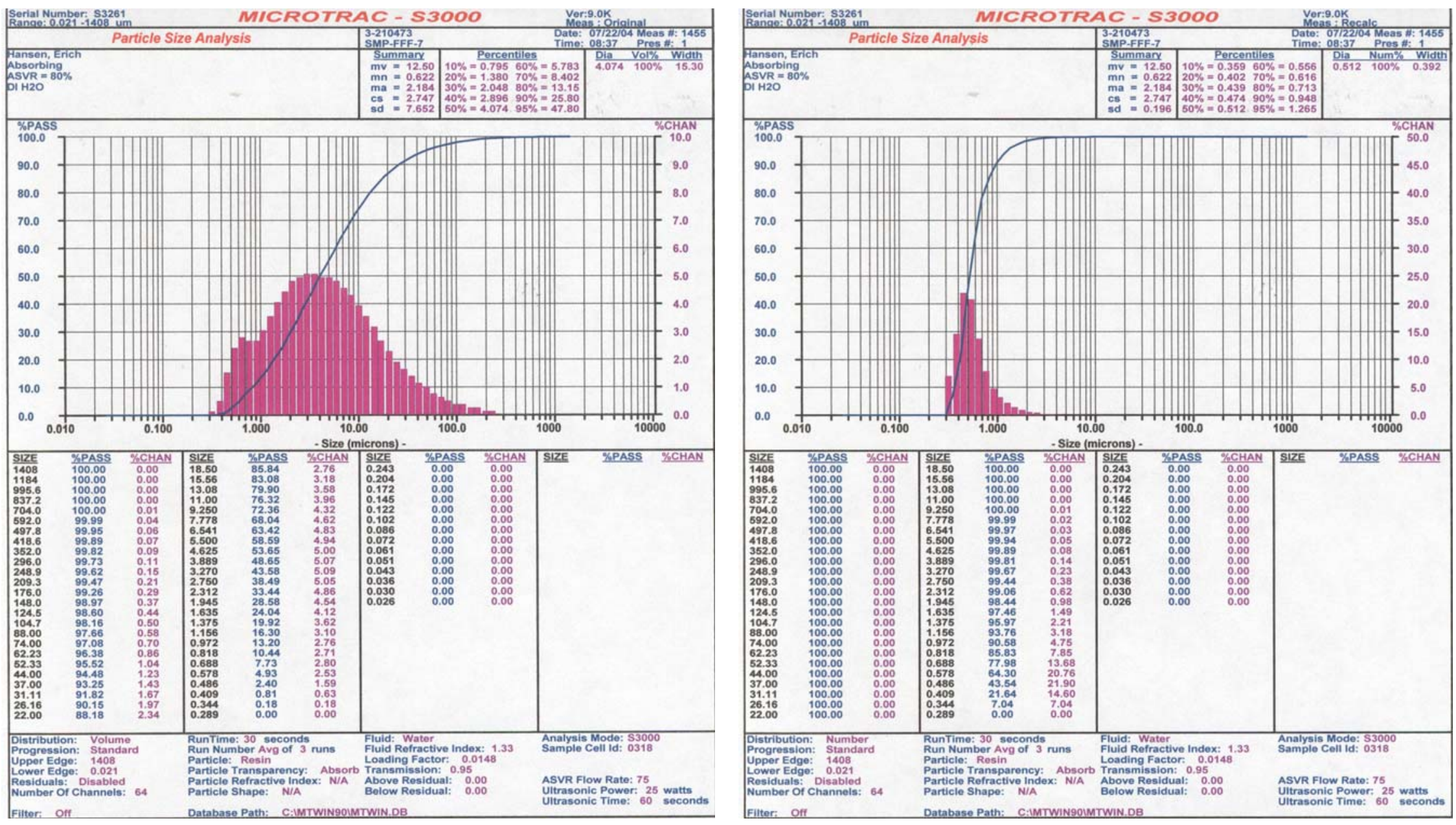

Figure B - 6: July 2004, SMP-FFF-7 Volume and Number Distribution 

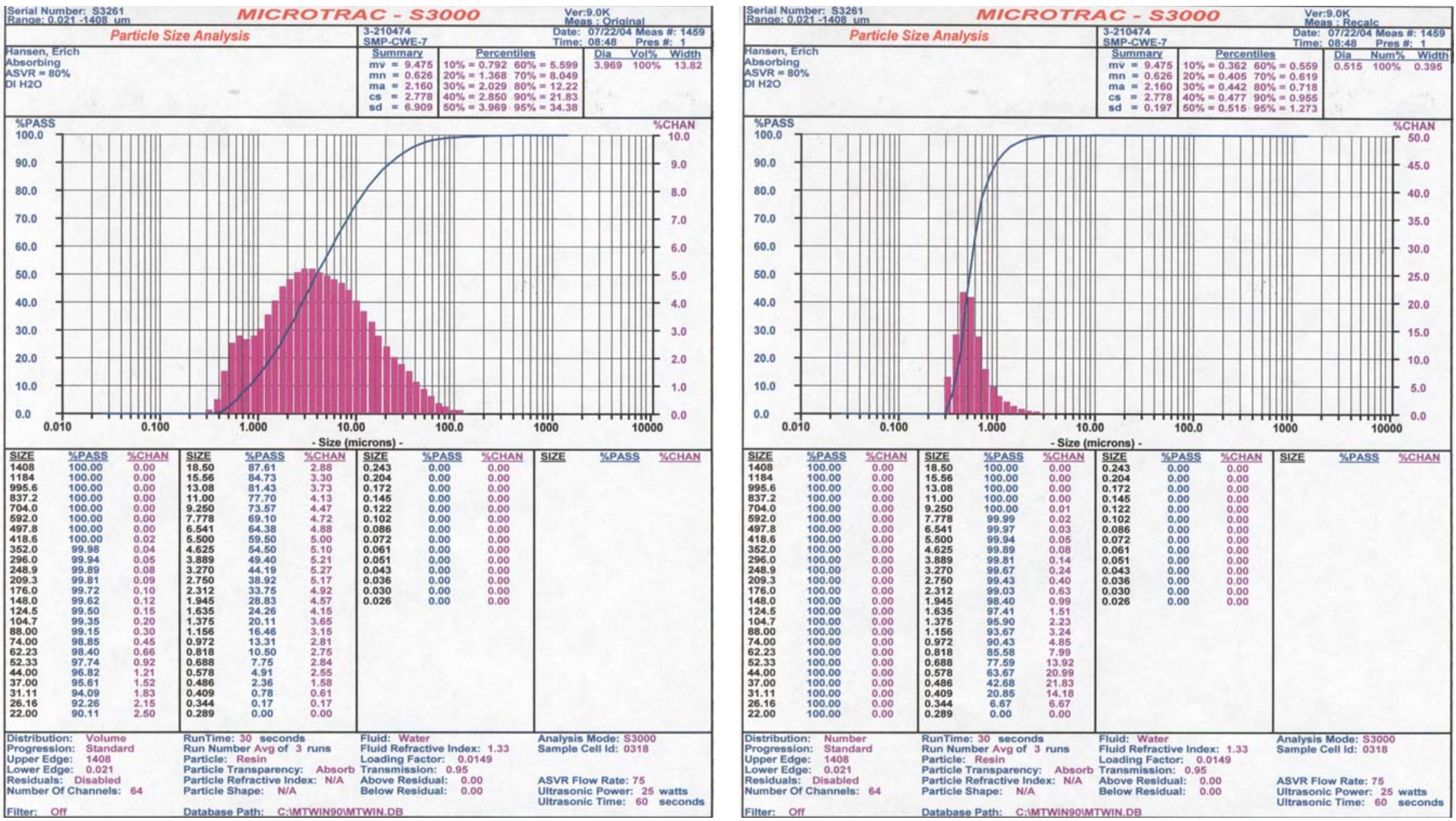

Figure B - 7: July 2004, SMP-CWE-7 Volume and Number Distribution 

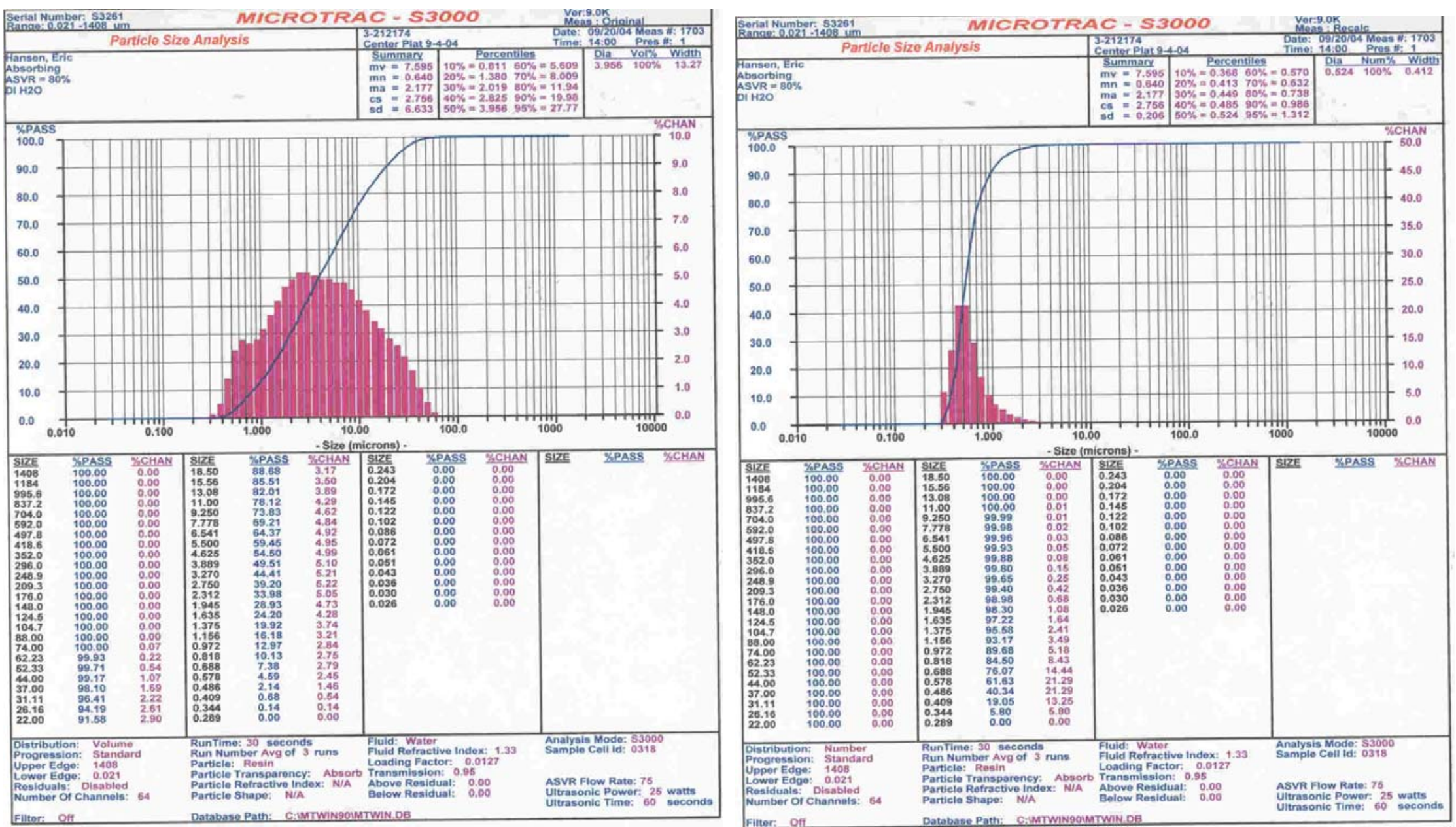

Figure B - 8: September 2004, SMP-ECR-1 Volume and Number Distribution 

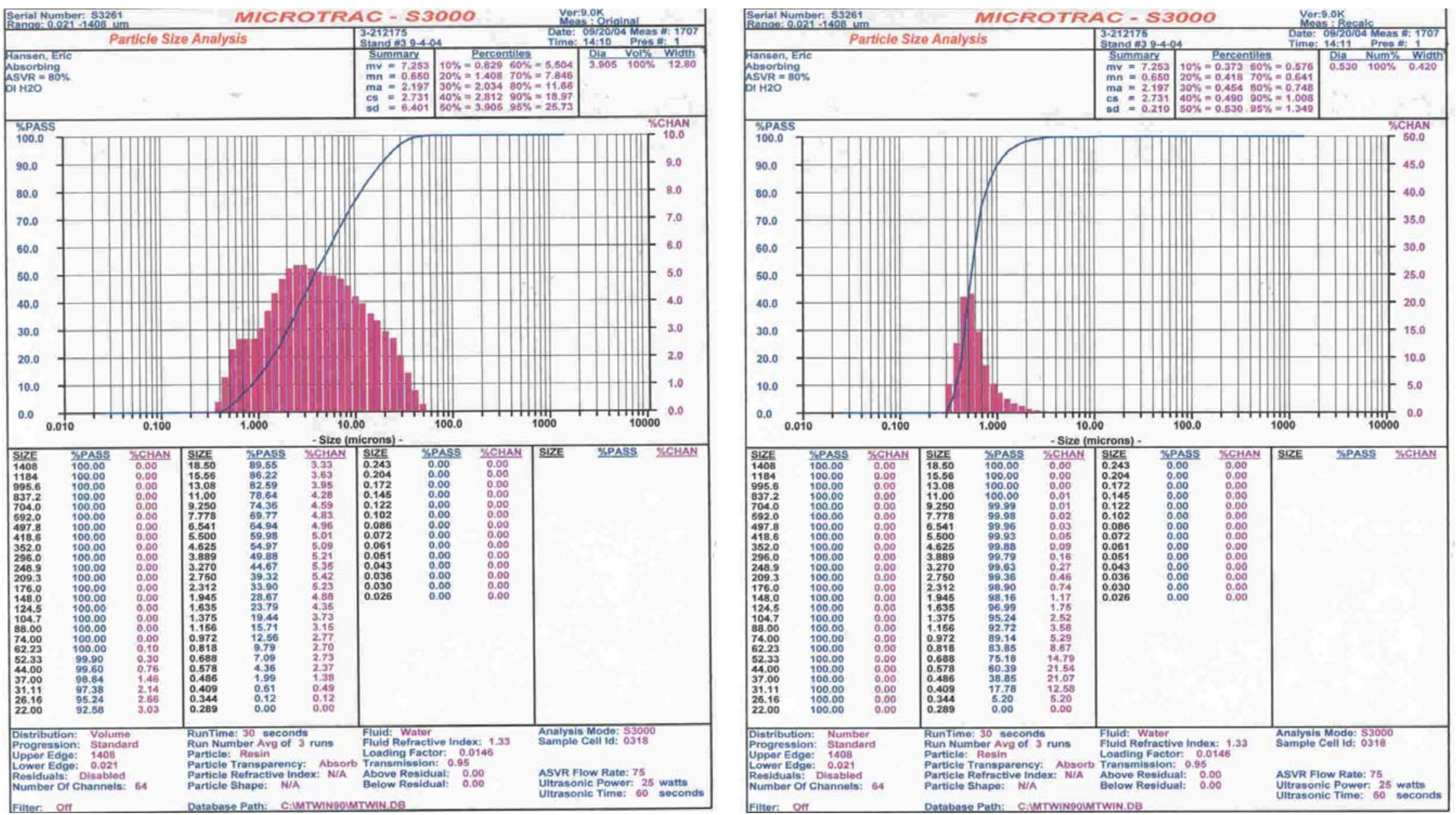

Figure B - 9: September 2004, SMP-FFF-1 Volume and Number Distribution 

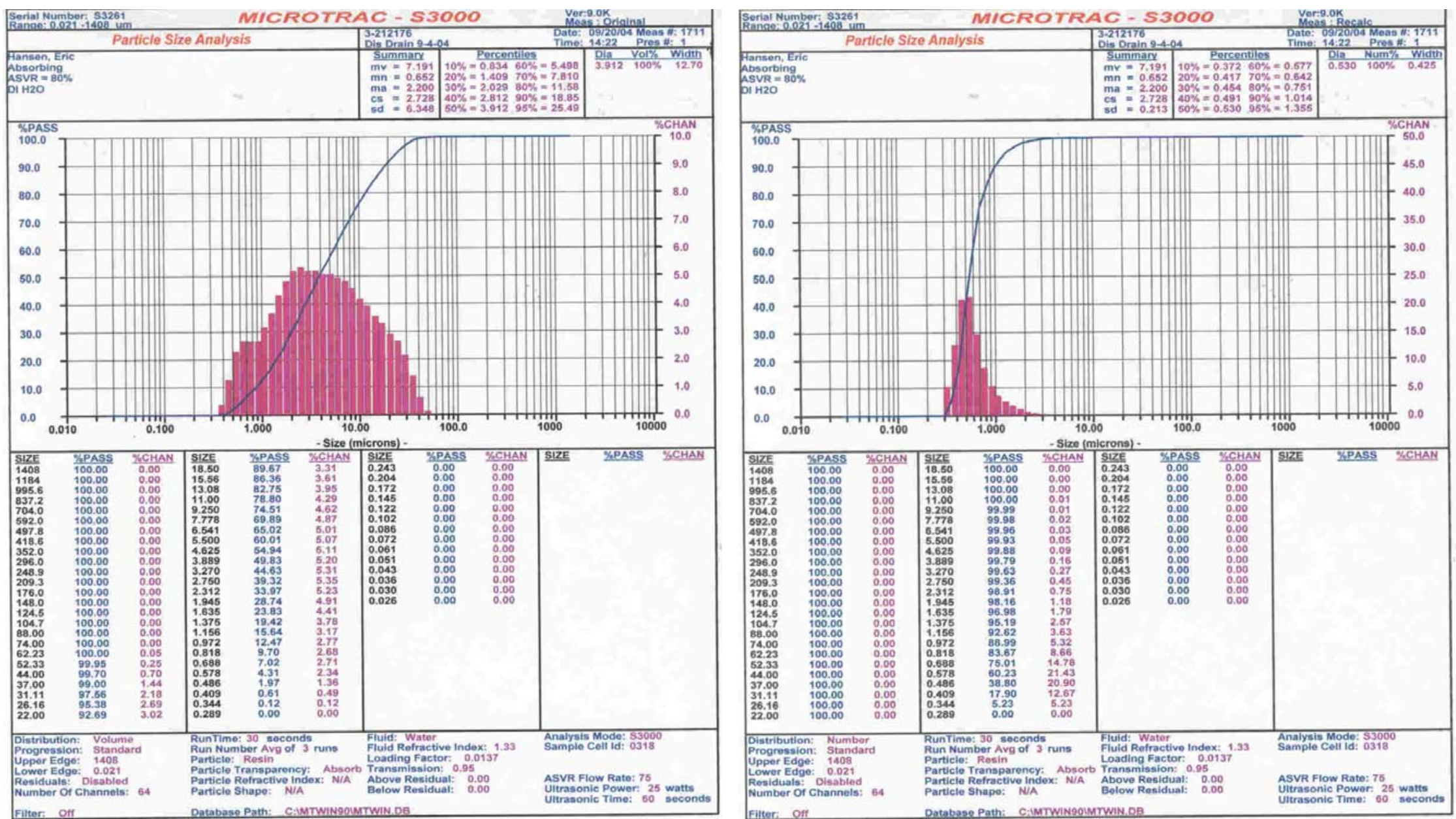

Figure B - 10: September 2004, SMP-CWE-1 Volume and Number Distribution 

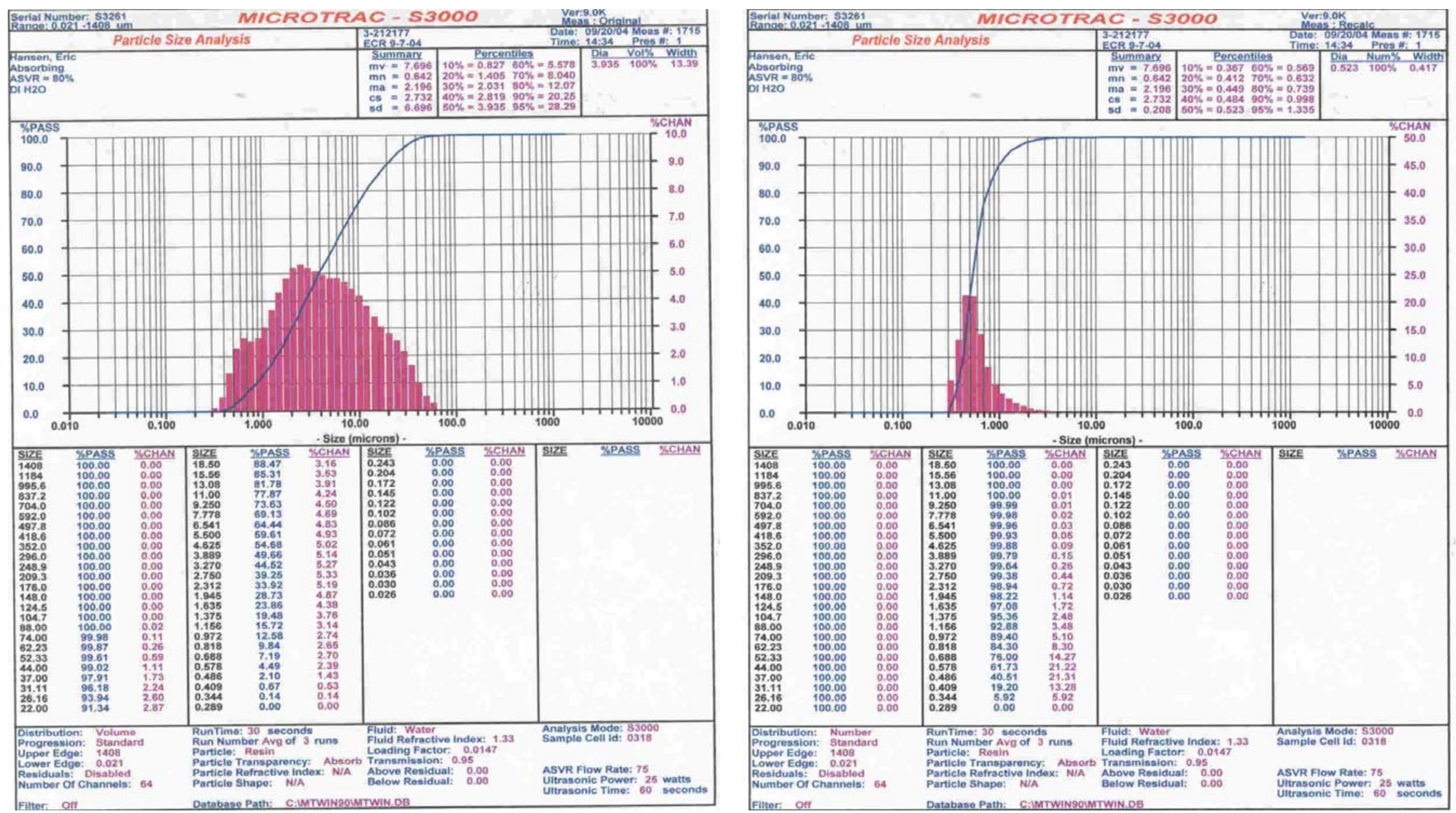

Figure B - 11: September 2004, SMP-ECR-4 Volume and Number Distribution 

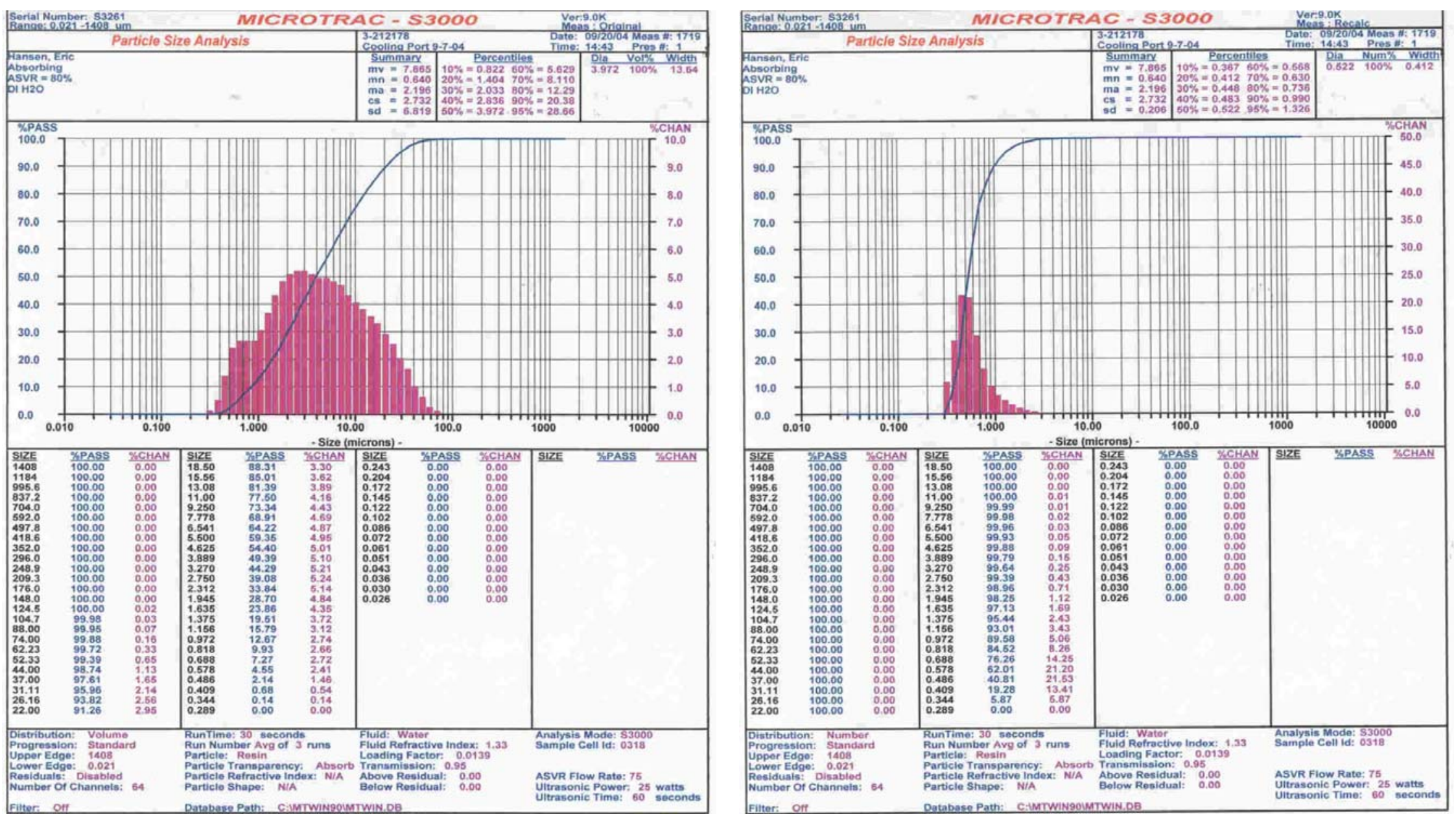

Figure B - 12: September 2004, SMP-CWE-4 Volume and Number Distribution 

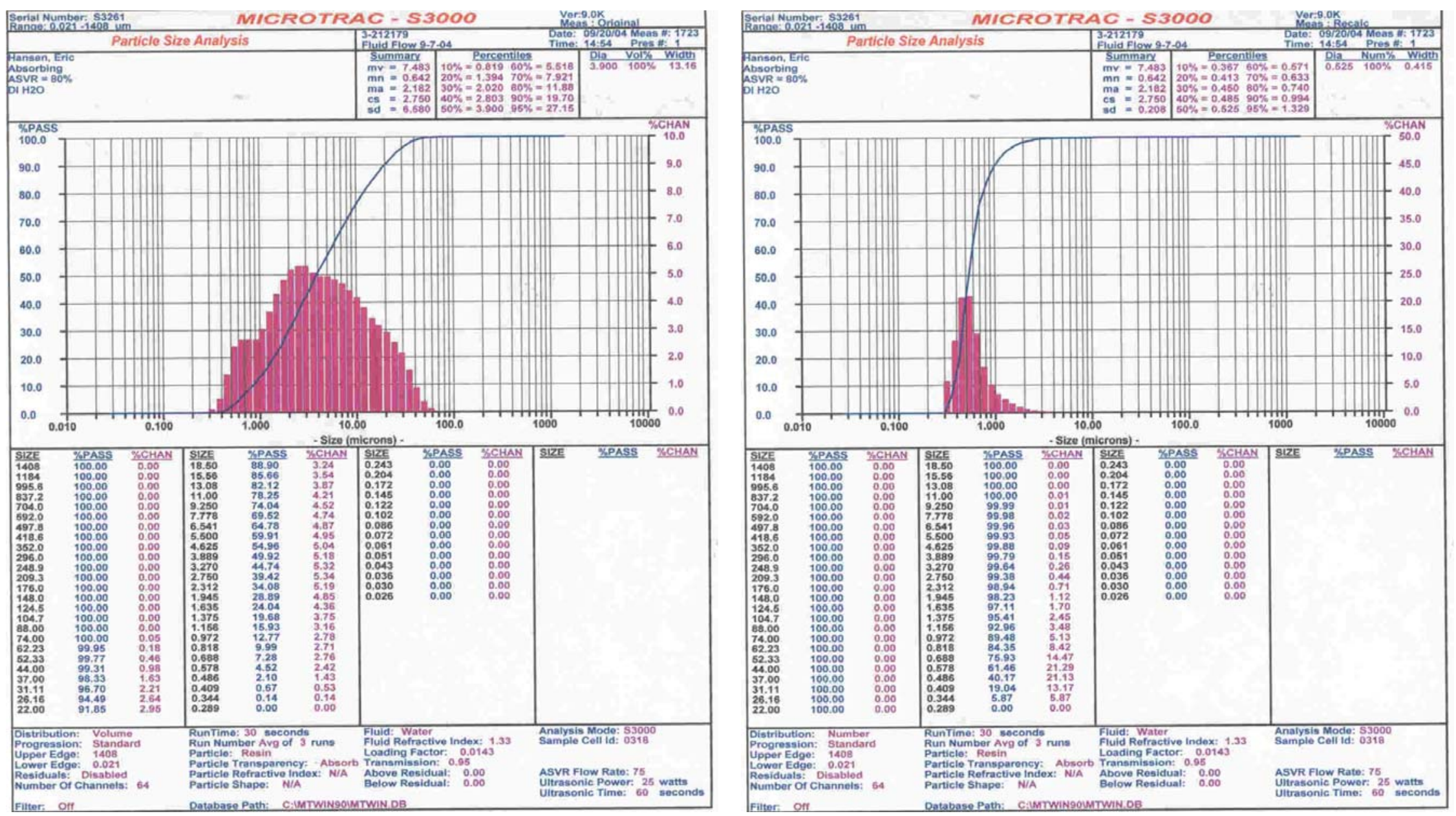

Figure B - 13: September 2004, SMP-FFF-4 Volume and Distribution 

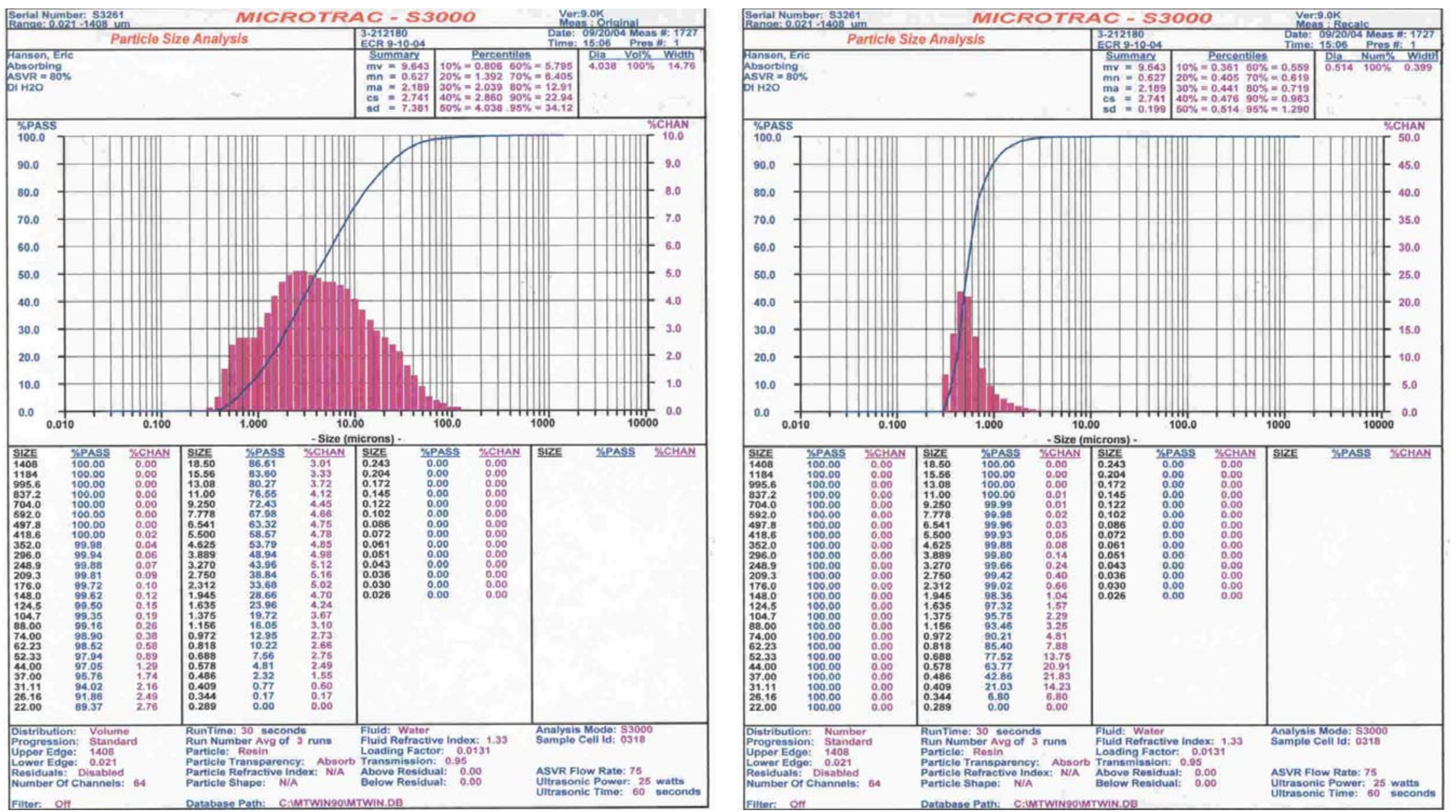

Figure B - 14: September 2004, SMP-ECR-7 Volume and Number Distribution 

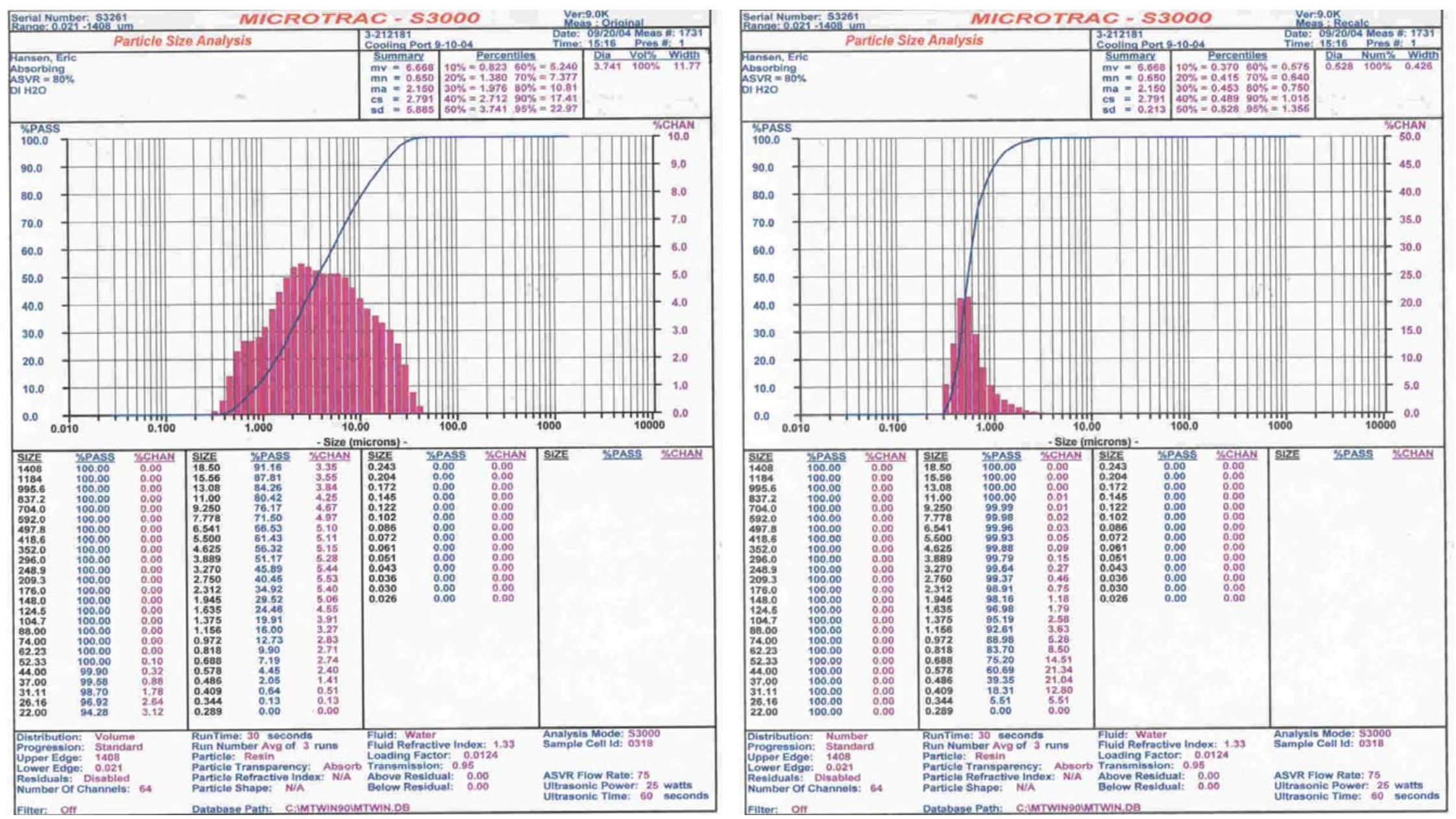

Figure B - 15: September 2004, SMP-CWE-7 Volume and Number Distribution 

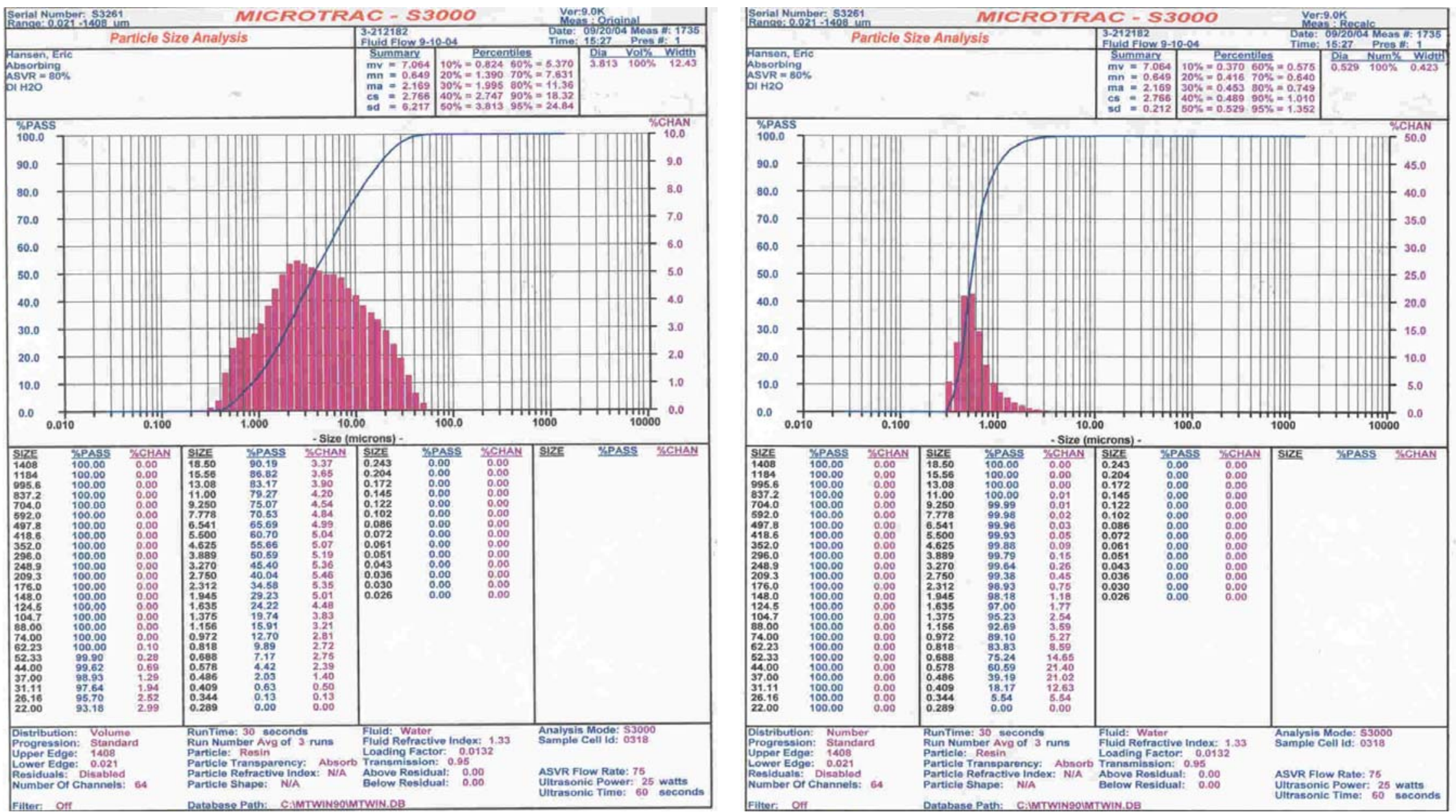

Figure B - 16: September 2004, SMP-FFF-7 Volume and Number Distribution 

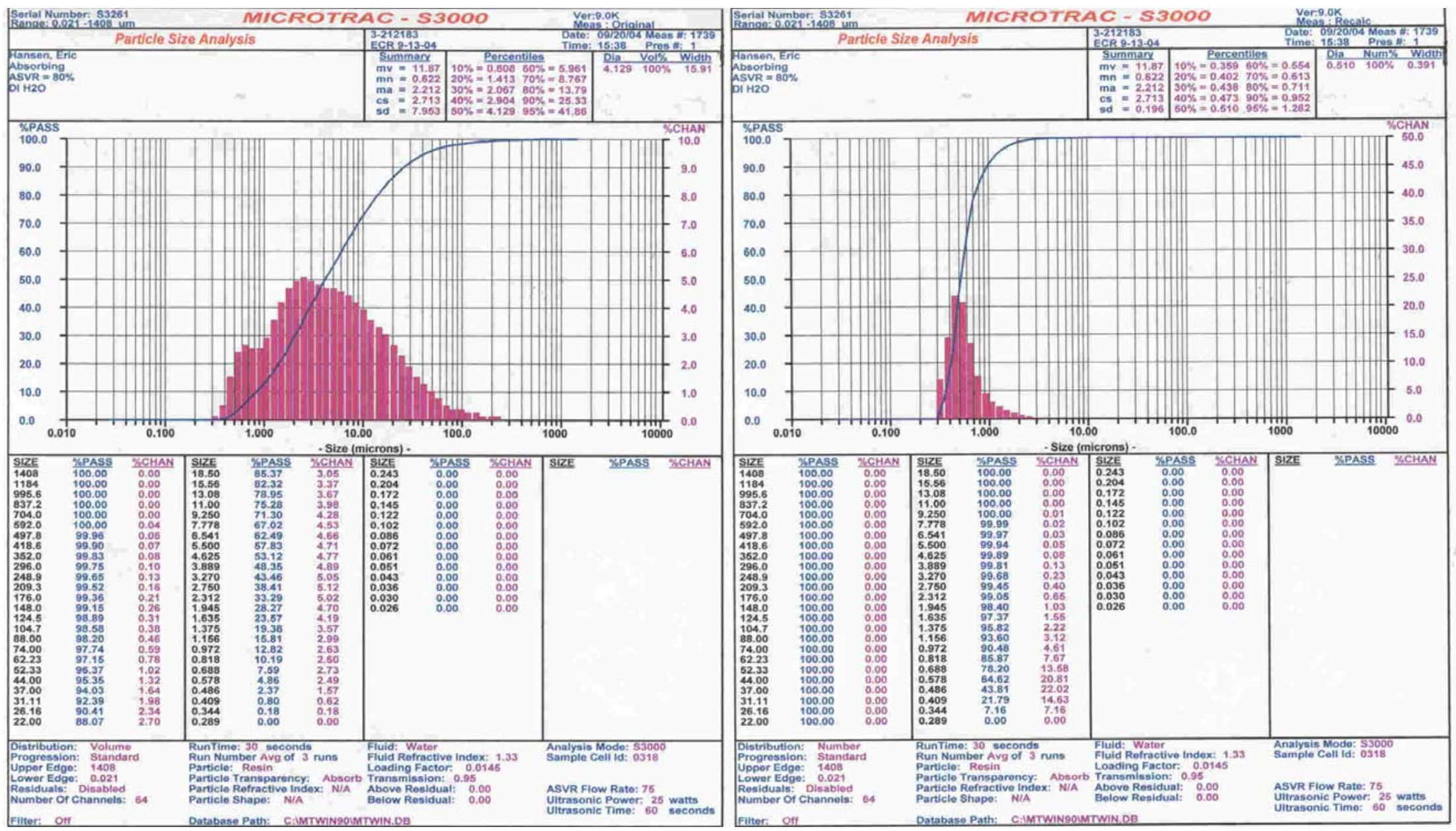

Figure B - 17: September 2004, SMP-ECR-10 Volume and Number Distribution 

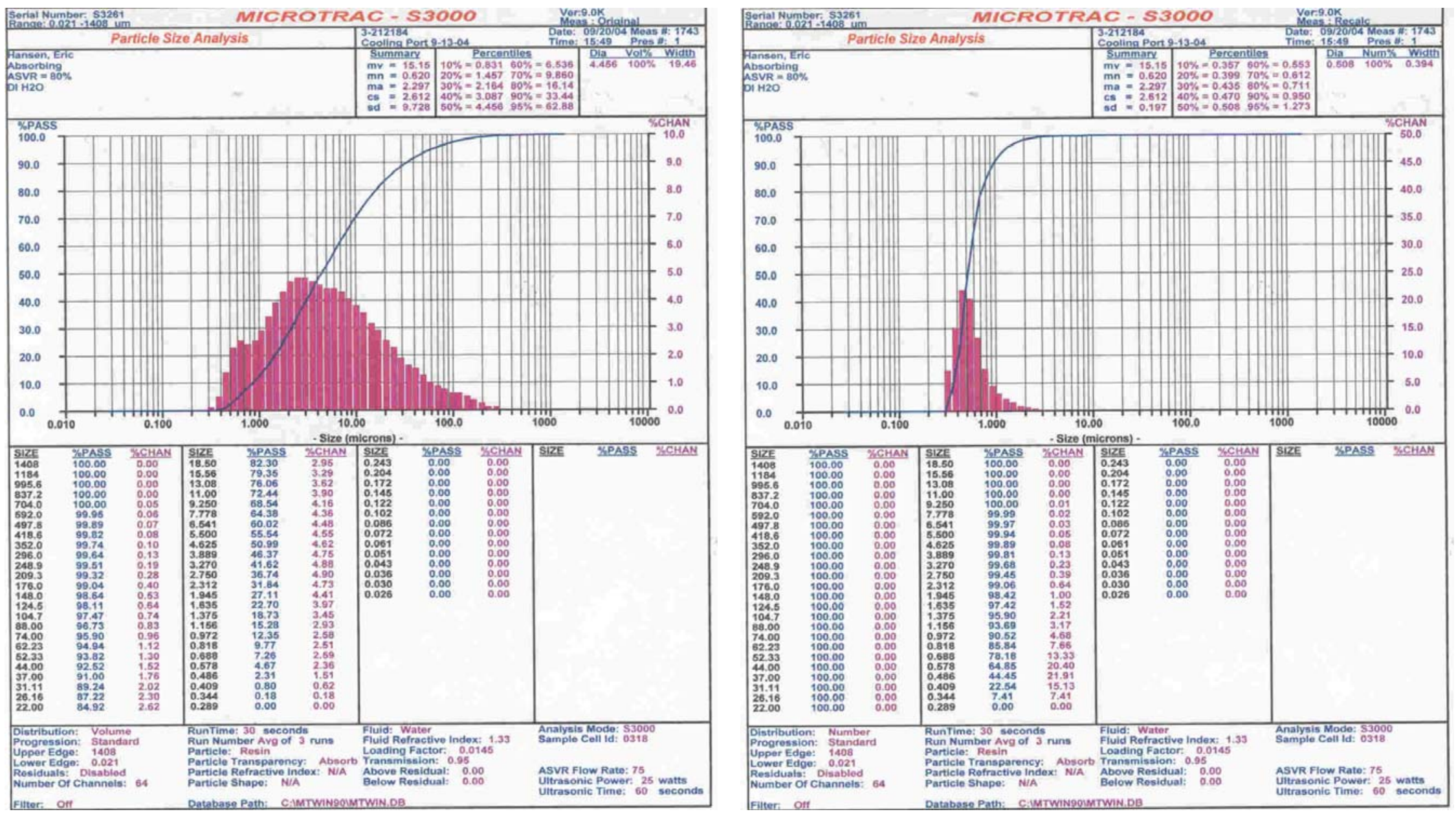

Figure B - 18: September 2004, SMP-CWE-10 Volume and Number Distribution 

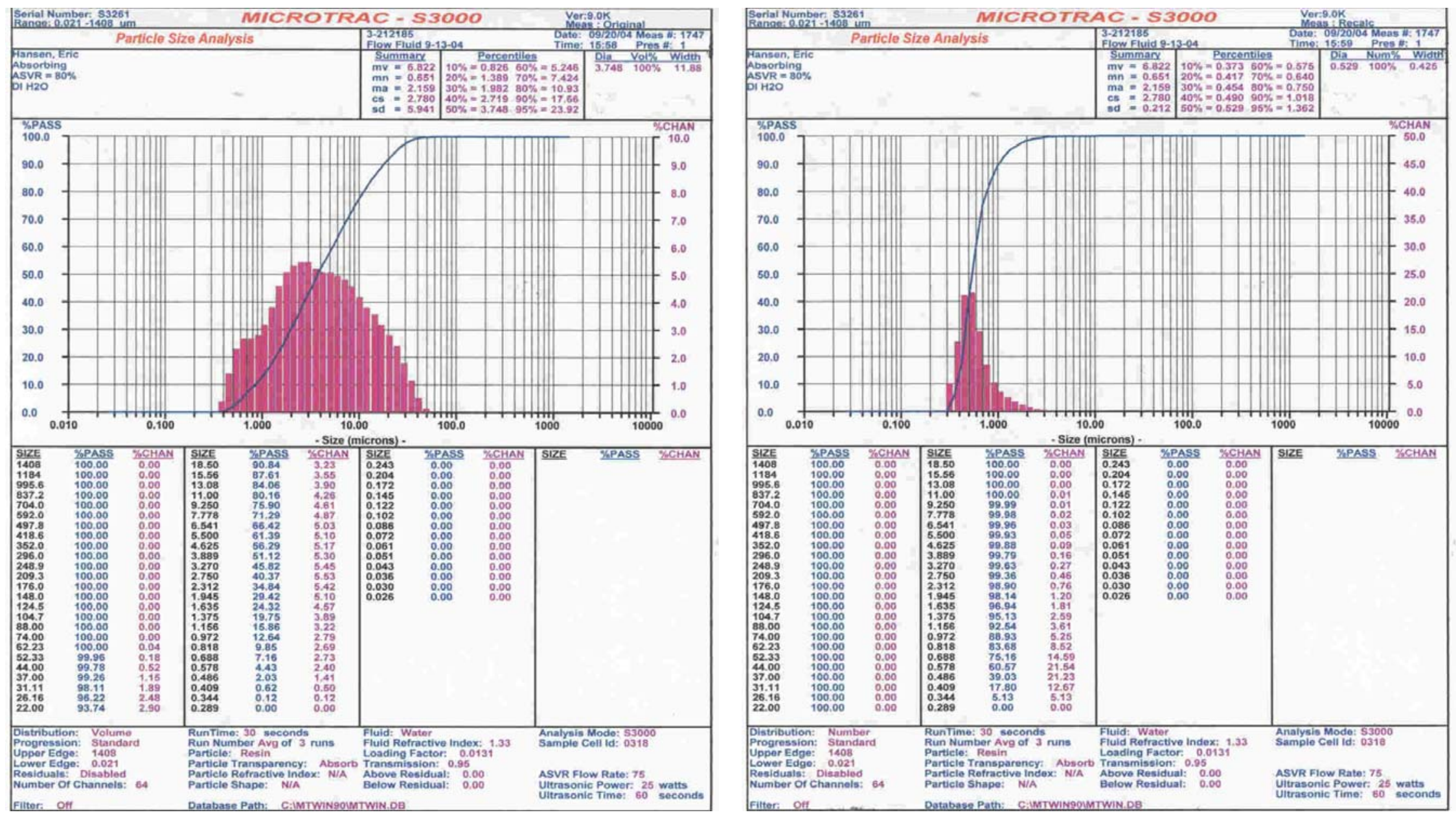

Figure B - 19: September 2004, SMP-FFF-10 Volume and Number Distribution 
WSRC-TR-2004-00401

Revision 1
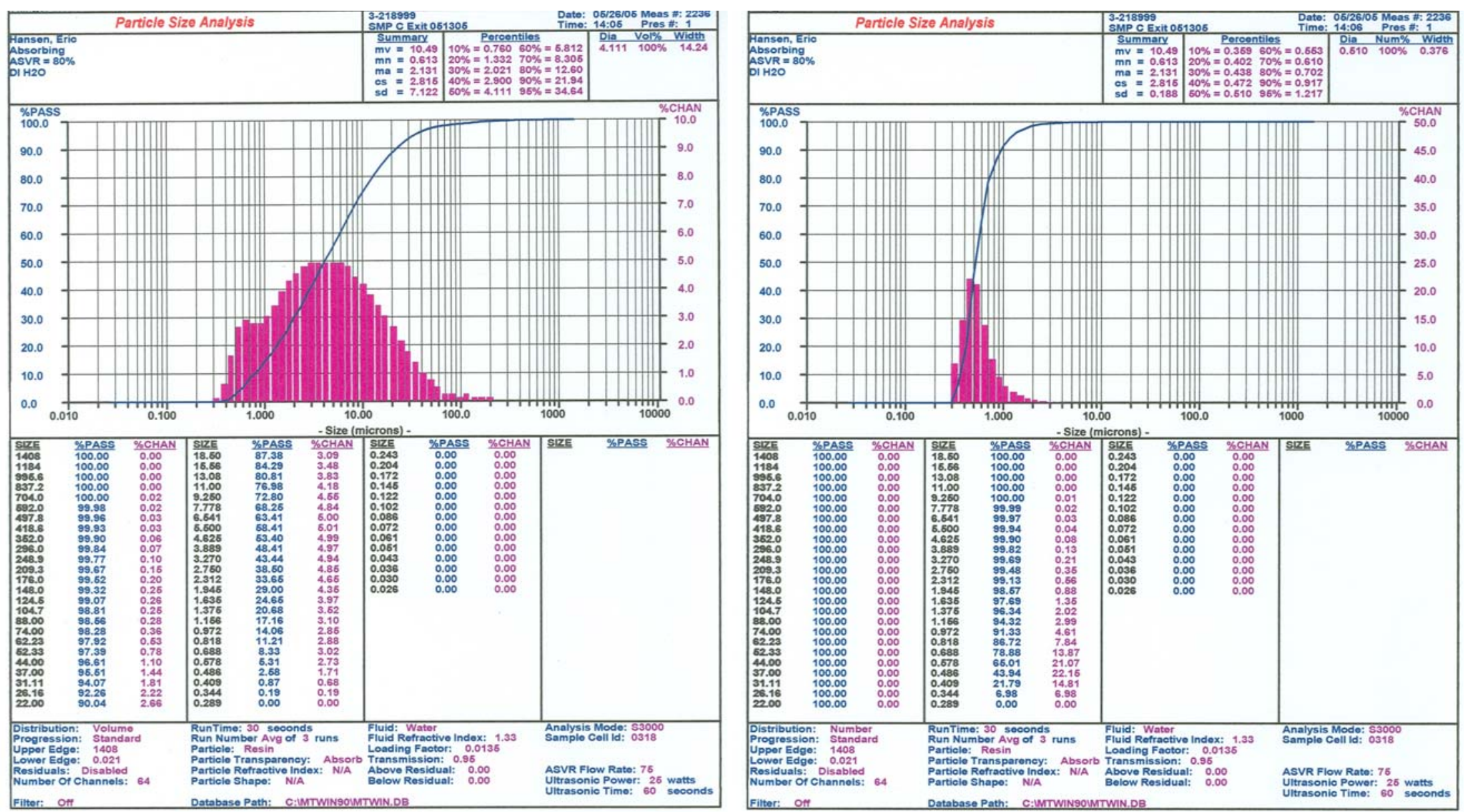

Figure B - 20: May 2005, SMP-CWE-1 Volume and Number Distribution 

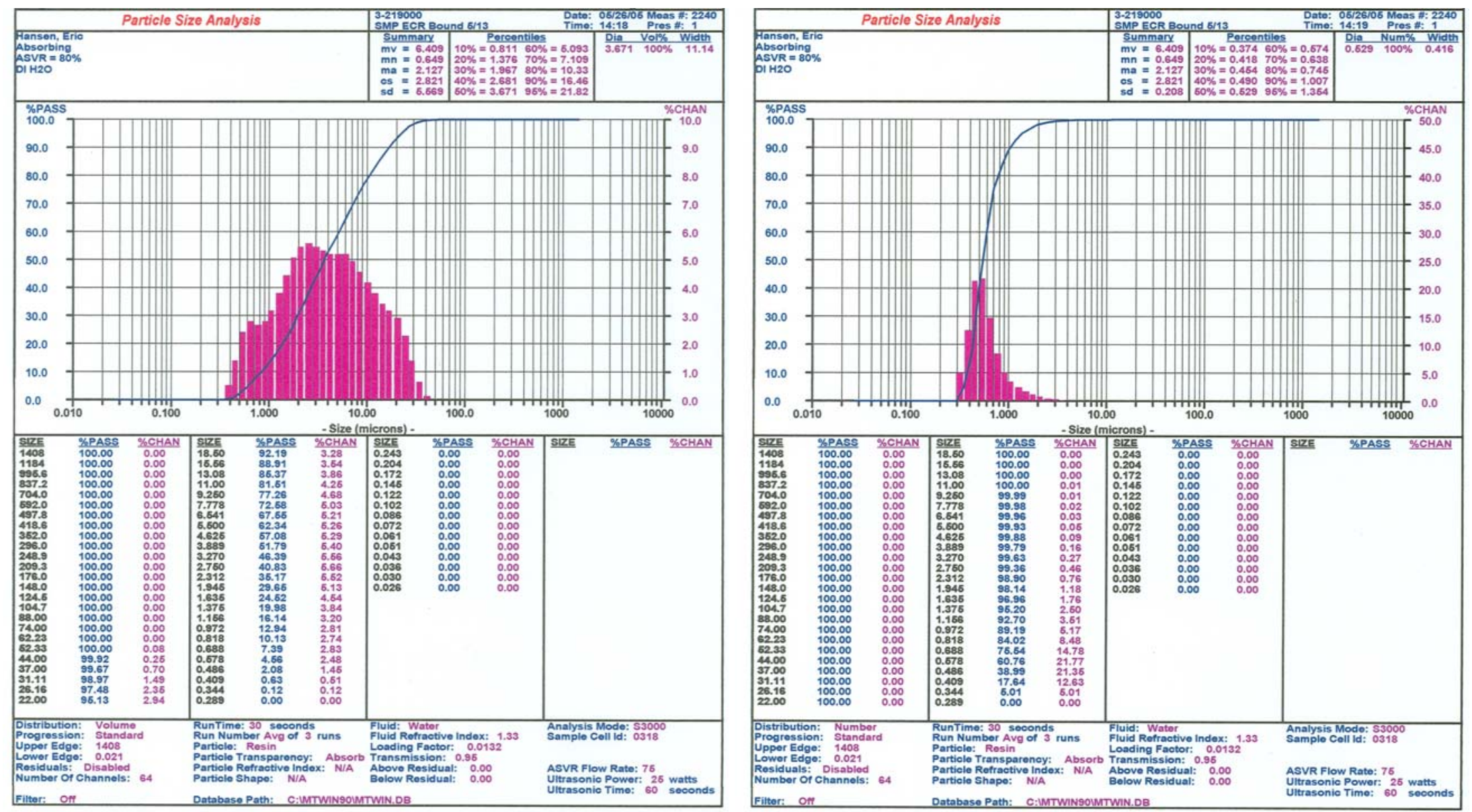

Figure B - 21: May 2005, SMP-FFF-1 Volume and Number Distribution 

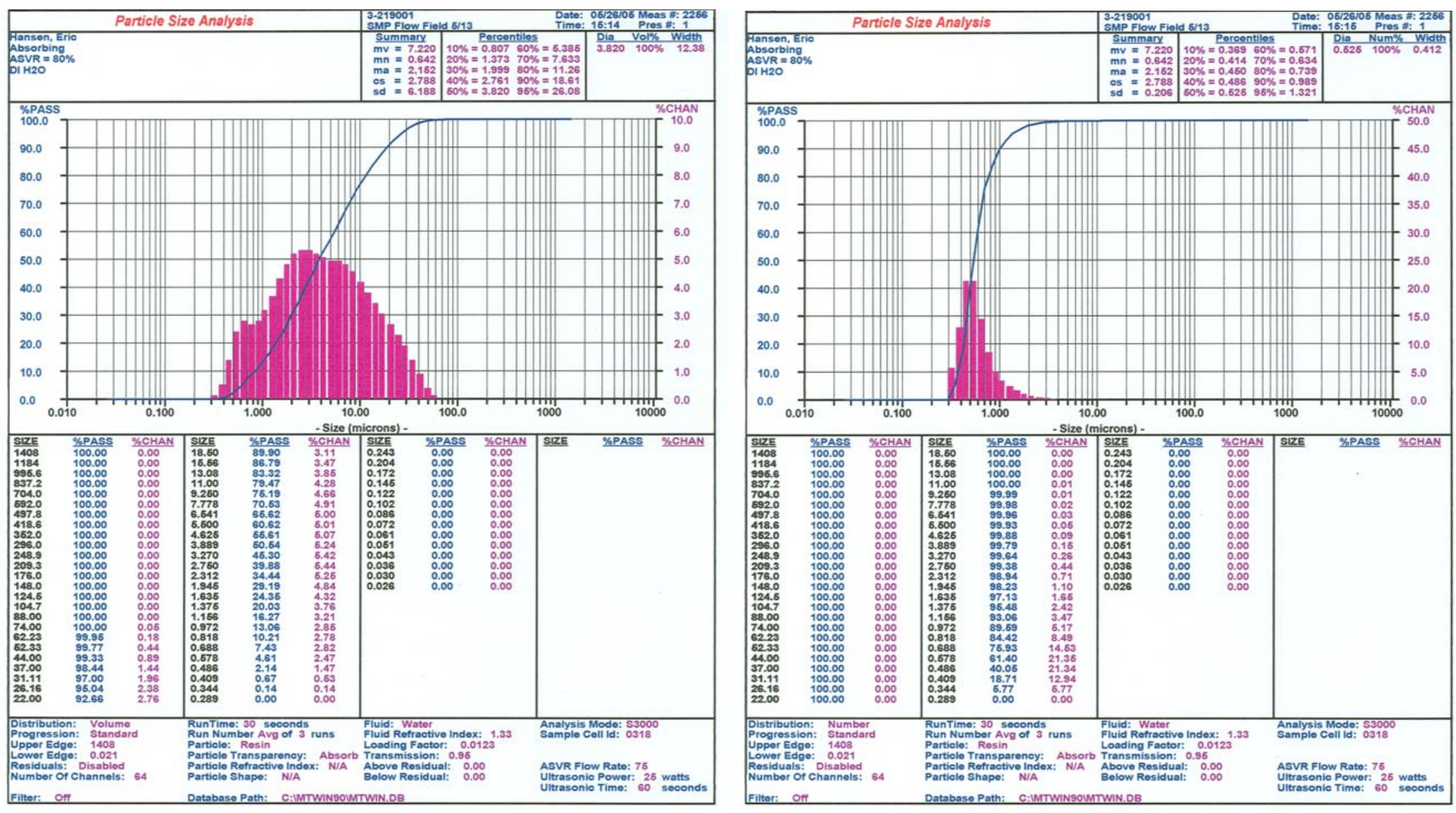

Figure B - 22: May 2005, SMP-ECR-1 Volume and Number Distribution 

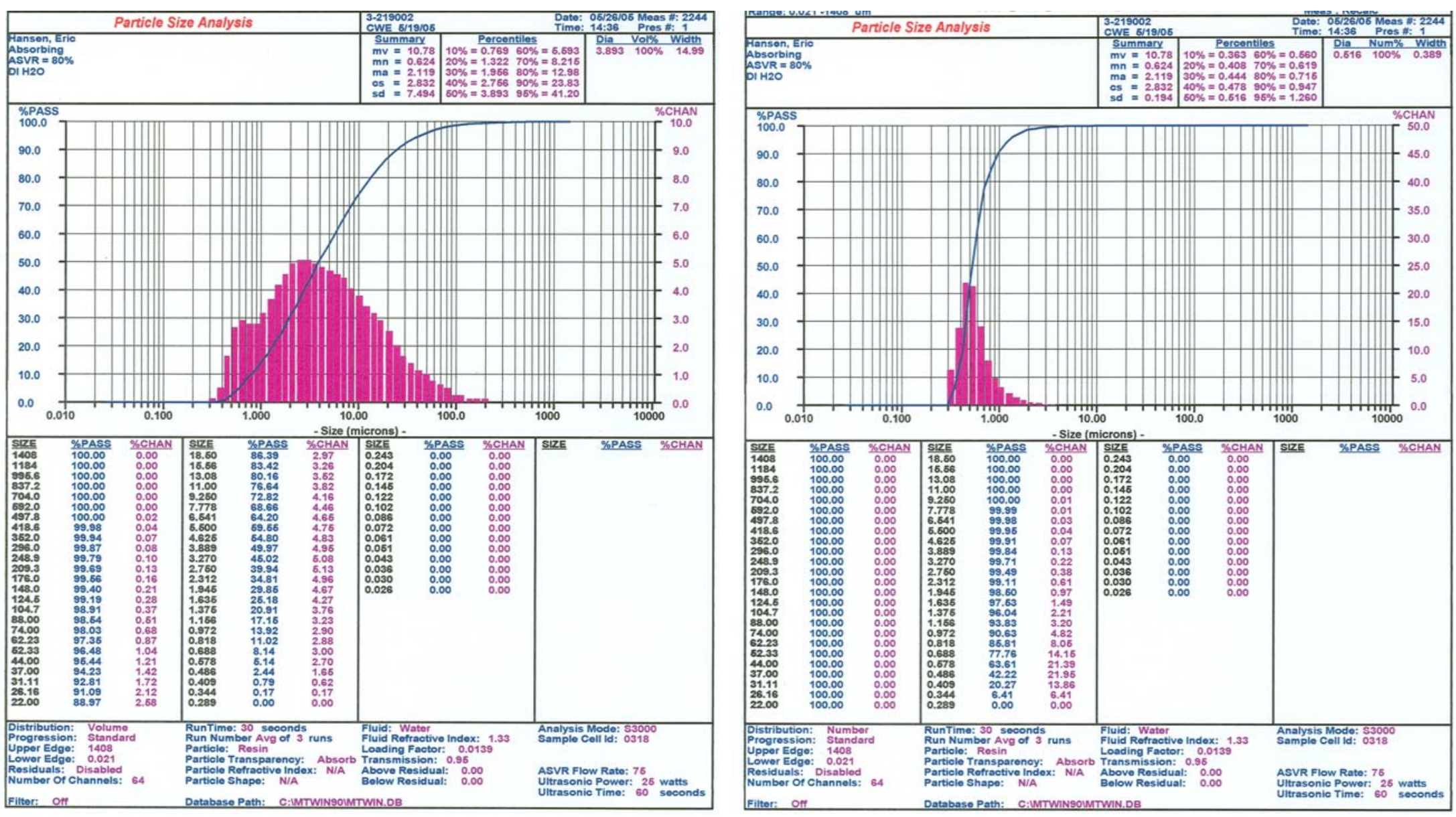

Figure B - 23: May 2005, SMP-CWE-7 Volume and Number Distribution 
WSRC-TR-2004-00401

Revision 1
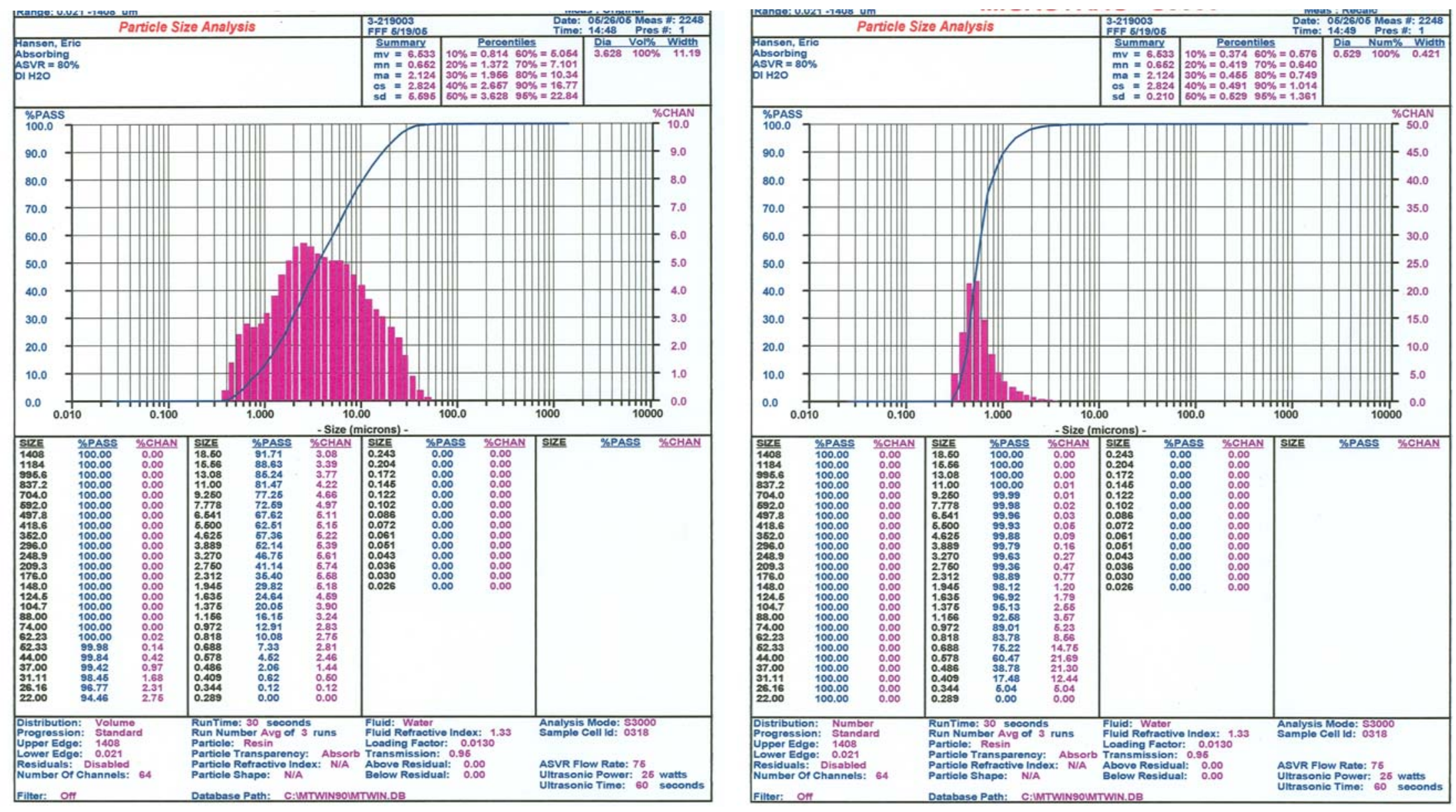

Figure B - 24: May 2005, SMP-FFF-7 Volume and Number Distribution 

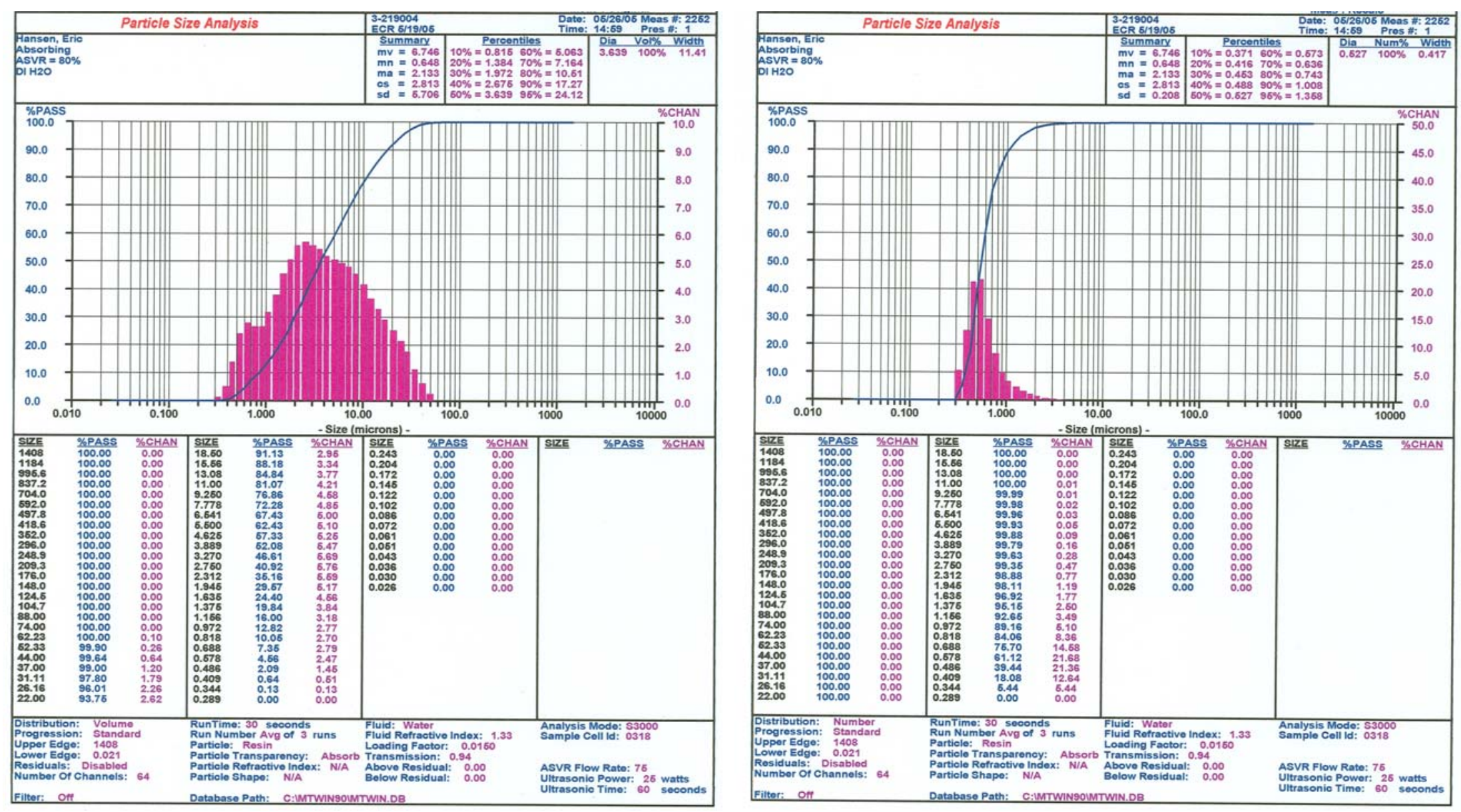

Figure B - 25: May 2005, SMP-ECR-7 Volume and Number Distribution 
WSRC-TR-2004-00401

Revision 1

APPENDIX C: KAOLIN VENDOR B-100 SPECIFICATIONS 


\section{TECHNICAL DATA}

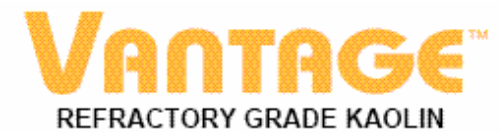

FEATURES AND BENEFITS

HEPHZIBAH, GA

VANTAGE ${ }^{\text {TM }}$ refractory grade clays are custom blends of hlghly refractlve kaollnite. These plastlc clays can be employed as the prlmary component of cast bodles, but are most commonly used to enhance the performance of calcined kaolinic clays. Their excellent plasticlty and dry strength Improve the productlon rate and shape retentlon of the refractory, and a high PCE value helps to extend refractory service llfe.

VANTAGE $^{\text {TM }}$ finds application In a varlety of Intermedlate to high duty flrebricks, shapes, Insulating bricks and saggars where good shape retention and spalling resistance is required. VANTAGE also serves as the plastic component In monolithic refractorles including castable, ramming and gunning mixes and mortars. Of critlcal Importance In these applications Is a high alumina to alkall ratlo to produce durable, highly refractory materlals with excellent stablilty. VANTAGE particle sIze distributions wIII also help to minimize drylng shrinkage prlor to Installation.

All VANTAGE ${ }^{\mathrm{TM}}$ flre clays are mined and processed under rigld QIP $^{5 \mathrm{~m}}$ statlstical quality assurance programs. The result Is consistent mineralogy, chemical and physical propertles, predictable results in demanding refractory appllcatlons.

CHEMICAL AND ANALYTICAL DATA

Mean Values. These Do Not Represent A Specification.

\begin{tabular}{|c|c|c|c|c|c|c|}
\hline & & $\underline{B-100}$ & $\underline{\mathrm{HT} 100}$ & $\underline{\text { LT100 }}$ & $\underline{\text { SLURRY C }}$ & $\underline{B-150}$ \\
\hline SIIIcon Dloxide & $\left(\mathrm{S} \mathrm{O}_{2}\right)$ & 45.00 & 44.50 & 44.70 & 44.70 & 45.40 \\
\hline Aluminum Oxide & $\left(\mathrm{Al}_{2} \mathrm{O}_{3}\right)$ & 38.00 & 38.60 & 38.50 & 38.60 & 39.25 \\
\hline TItanlum Dloxide & $\left(\mathrm{TIO}_{2}\right)$ & 1.54 & 1.45 & 1.62 & 1.68 & 1.54 \\
\hline Iron OxIde & $\left(\mathrm{Fe}_{2} \mathrm{O}_{3}\right)$ & .77 & .40 & .32 & .34 & .66 \\
\hline Calclum OxIde & $(\mathrm{CaO})$ & .04 & .04 & .03 & .04 & .02 \\
\hline Magneslum Oxide & (MgO) & .08 & .05 & .13 & .13 & .14 \\
\hline Potasslum OxIde & $\left(\mathrm{K}_{2} \mathrm{O}\right)$ & .51 & .28 & .10 & .09 & .24 \\
\hline Sodlum OxIde & $\left(\mathrm{Na}_{2} \mathrm{O}\right)$ & .06 & .03 & .08 & .08 & .06 \\
\hline \multirow[t]{2}{*}{ Loss on Ignition } & (LOI) & 13.50 & 13.70 & 13.70 & 14.00 & 13.70 \\
\hline & & & $\begin{array}{l}\text { HIGH TEMP } \\
\text { SP100 }\end{array}$ & $\begin{array}{l}\text { LOW TEMP } \\
\text { SP100 }\end{array}$ & $\begin{array}{c}\text { Sodlum } \\
\text { Polyacrylate } \\
\text { Dispersant }\end{array}$ & \\
\hline M.B.I (meq/100g) & & 3.2 & $2.6-3.0$ & $1.9-2.4$ & $1.8-2.2$ & 3.4 \\
\hline SSA $\mathrm{m}^{2} / \mathrm{g}$ & & 15.5 & $13.0-14.5$ & $10.2-12.0$ & 10.6 & 15.3 \\
\hline pH @10\% Sollds & & $4.5-5.5$ & $4.5-5.5$ & $4.5-5.5$ & $4.8-5.8$ & $4.5-5.5$ \\
\hline M.O.R. (Drled @ 230 & $\left.{ }^{\circ} \mathrm{F}\right) \mathrm{lbf} / \mathrm{In}^{2}$ & $200-300$ & $100-200$ & $100-200$ & $100-200$ & $100-200$ \\
\hline \multicolumn{2}{|c|}{$\%$ Water Absorption $1120^{\circ} \mathrm{C}$} & 24.1 & 23.2 & 23.4 & 22.5 & 22.3 \\
\hline & $1220^{\circ} \mathrm{C}$ & 15.5 & 16.3 & 15.4 & 16.4 & 16.1 \\
\hline \%LInear Shrinkage D & Dry-Flred $1120^{\circ} \mathrm{C}$ & 3.9 & 4.2 & 4.0 & 3.9 & 4.4 \\
\hline & $1220^{\circ} \mathrm{C}$ & 5.2 & 5.6 & 5.9 & 4.9 & 6.0 \\
\hline
\end{tabular}




\section{TECHNICAL DATA}

\section{VAกTAGE}

PARTICLE SIZE ANALYSIS AND PROPERTIES

Mean Values. These Do Not Represent A Specification

Mean Percent By Welght on OxIde Basis

$\begin{array}{ccccccc} & \text { MICRONS } & \text { B-100 } & \text { HI100 } & \text { LI100 } & \text { SLURRYC } & \text { B-150 } \\ \% \text { FIner } & <20 \mu & 98 & 98 & 97 & 97 & 98 \\ & <10 \mu & 92 & 92 & 88 & 89 & 90 \\ <5 \mu & 83 & 81 & 76 & 75 & 77 \\ <2 \mu & 67 & 58 & 56 & 54 & 58 \\ <1 \mu & 56 & 42 & 40 & 39 & 47 \\ <0.5 \mu & 42 & 26 & 22 & 24 & 32\end{array}$

\section{ORDERING INFORMATION}

Shipping Polnt:

Avallabllity:
HEPHZIBAH, GEORGIA

ORIGINATING RAIL CARRIER: NORFOLK SOUTHERN

50 LB. BAGS, INTERMEDIATE BULK BAGS, AND BULK TRUCK AND RAIL

FOR PRODUCT INFORMATION AND CUSTOMER SERVICE:

US and Canada $800-243-9004 \quad$ Fax 800-243-9005

HEALTH HAZARD WARNING: Long term 9 Xposure can cause pneumoco njosis. This material contains crystalling sillca which can cause pnyumoconlosis. Pnoumoconlosis is a

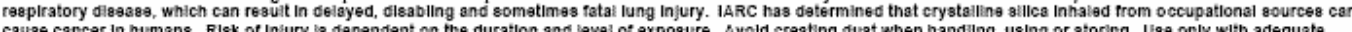
cause cancer in humans. Rlsk of injury is dependent on the duration and lavel of exposure. Avold creating dust when handiling, using or storing. Usa only with adequate

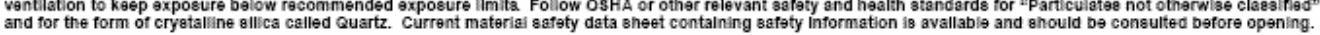

Notice: While information contained hereln lo correct to the best of our knowiedge. Unimin Corporation hereln dleciaims any warrantles as to the accuracy of the same. Recommendations of suggestions are made without guarantes or representation as to result, Bince conditions of usage are beyond our control. Als materials are sold to Unimin Corporation standarde terms and conditions of aale and the conditions that buyer shall make his own tests to determine the suitablity of such product for buyer's purpose. No
statement contained hergin ahail be conetrugd as a recommendation to infringe any patent.

Kaolinsulica Containing

Vantagerwis a trademark of UNIMIN Corporation or its subsidiaries. All righte reserved.

Hephzibah - Vantage 08:01 
WSRC-TR-2004-00401

Revision 1

\section{APPENDIX D: METHOD USED TO DETERMINE SAND CONTRIBUTION}


Known Measured Data:

$\mathrm{M}_{\mathrm{T}}=$ Total mass of slurry sample (g)

$\mathrm{wt}_{\mathrm{TS}}=$ Weight percent total solids in slurry

$\mathrm{M}_{>45}=$ Mass of particles greater than $45 \mu \mathrm{m}$ (g)

wt $\%_{\mathrm{K}>45}=$ Weight percent of kaolin greater than $45 \mu \mathrm{m}$ in kaolin source

Calculated Data:

$\mathrm{M}_{\mathrm{TS}}=$ Mass of total solids ( $\mathrm{g}$ )

$\mathrm{M}_{\mathrm{S}}=$ Mass of sand \{assumes sand particles are all greater than $\left.45 \mu \mathrm{m}\right\}(\mathrm{g})$

$\mathrm{M}_{\mathrm{K}>45}=$ Mass of kaolin greater than $45 \mu \mathrm{m}(\mathrm{g})$

$\mathrm{M}_{\mathrm{K}}=$ Mass of kaolin (g)

$\mathrm{wt} \%_{\mathrm{s}}=$ Weight percent of sand in total solids

$\mathrm{wt}_{\mathrm{k}>45 \mu \mathrm{m} \text { in dried solids }>45 \mu \mathrm{m}}=$ Weight percent of kaolin greater than $45 \mu \mathrm{m}$ in particles greater than $45 \mu \mathrm{m}$

$$
\begin{aligned}
& M_{T S}=M_{T} \cdot \frac{w t \%_{T S}}{100 \%} \\
& M_{T S}=M_{K}+M_{S} \\
& M_{>45}=M_{K>45}+M_{S} \\
& M_{K>45}=M_{K} \cdot \frac{w t \%_{K>45}}{100 \%} \\
& w t \%_{S}=\frac{M_{S}}{M_{T S}} \cdot 100 \% \\
& w t \%_{\text {Kaolin }>45 \mu m \text { in dried solids }>45 \mu m}=\frac{M_{K>45}}{M_{>45}} \cdot 100 \%
\end{aligned}
$$

Subtract (3) from (2), substitute (1) and (3) and solve for $\mathrm{M}_{\mathrm{K}}$.

$$
\begin{aligned}
& M_{T S}-M_{>45}=M_{K}-M_{K>45}=M_{K}-M_{K} \cdot \frac{w t \%_{K>45}}{100 \%}=M_{K}\left(1-\frac{w t \%_{K>45}}{100 \%}\right) \\
& M_{K}=\frac{M_{T S}-M_{>45}}{\left(1-\frac{w t \%_{K>45}}{100 \%}\right)}=\frac{M_{T} \cdot \frac{w t \%_{T S}}{100 \%}-M_{>45}}{\left(1-\frac{w t \%_{K>45}}{100 \%}\right)}
\end{aligned}
$$

Solve for $\mathrm{M}_{\mathrm{k}>45}$ using equation (4). Solve for $\mathrm{wt} \%_{\mathrm{k}>45 \mu \mathrm{m} \text { in dried solids }>45 \mu \mathrm{m}}$ using equation (7).

Solve for $\mathrm{M}_{\mathrm{S}}$ using equation (2) and $\mathrm{wt} \%_{\mathrm{S}}$ using equation (5). 


\section{Distribution:}
J. E. Marra, SRNL
E. W. Holtzscheiter, SRNL
R. E. Edwards, SRNL
D. A. Crowley, 999-W
W. E. Stevens, SRNL
S. L. Marra, 999-W
T. B. Calloway, 999-W
C. C. Herman, 773-42A
N. E. Bibler, SRNL
C.M. Jantzen, SRNL
J. R. Harbour, 773-42A
G. C. Wicks, SRNL
C. A. Langton, 773-43A
R. E. Eibling, 999-W
S. Y. Lee, 773-42A
N. F. Chapman, 703-H
J. E. Herbert, 704-108F
M. R. Gober, 704-82H
D. J. Altman, 704-70F
D. B. Stefanko, 678-8T
T. G. Collins, 241-197H
T. M. Punch, 704-71F
J. J. Purohit, 704-71F
M. Hubbard, 704-70F 